\title{
Changes in Stratigraphic Nomenclature by the U.S. Geological Survey, 1979
}

GEOLOGICAL SURVEY BULLETIN 1502-A 



\section{Changes in Stratigraphic Nomenclature by the U.S. Geological Survey, 1979}

By N. F. SOHL and W. B. WRIGHT

GE OL OGICA L S UR VEY B ULLETIN 1502 - A

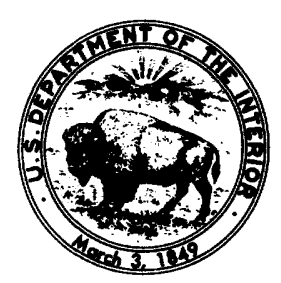


UNITED STATES DEPARTMENT OF THE INTERIOR

JAMES G. WATT, Secretary

GEOLOGICAL SURVEY

Doyle G. Frederick, Acting Director

Library of Congress catalog-card No. 81-600039 Washington, D.C. 20402 


\section{CONTENTS}

PAGE

New geologic time chart $\ldots \ldots \ldots \ldots \ldots \ldots \ldots \ldots \ldots \ldots \ldots$. . . . .

Listing of nomenclatural changes..................... 4

References cited $\ldots \ldots \ldots \ldots \ldots \ldots \ldots \ldots \ldots \ldots \ldots \ldots \ldots \ldots \ldots$ A87

Stratigraphic names in the New London area, southeastern Connecticut:

a revision, by Richard Goldsmith ..................... A91

Jabez Sandstone Member: a new member of the Fort Payne Formation

(Mississippian), south-central Kentucky, by Roy C. Kepferle,

Wayne A. Pryor, J. Barry Maynard, and James Harrell . . . . . . . . . Al04

The Wando Formation (upper Pleistocene) in the Charleston,

South Carolina, area, by Lucy McCartan, Robert E. Weems, and

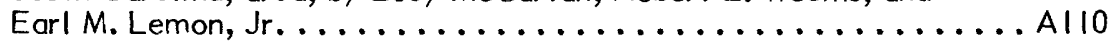

Kendrick Shale Member of the Breathitt Formation in eastern Kentucky,

by Charles L. Rice ......................... All7

Adoption, redefinition, and extended use of the name Collinsville Formation and its members and related formations in western Connecticut and western Massachusetts by Rolfe S. Stanley . . . . . . . . . Al23

Redefinition of the Cobble Mountain Formation in southwestern Massachusetts, and north-central Connecticut, by Rolfe S. Stanley,

Douglas A. Knapp, and Norman L. Hatch, Jr. . . . . . . . . . A AI27

The Putney Volcanics in southeastern Vermont and north-central

Massachusetts, by Newell J. Trask .................. Al33

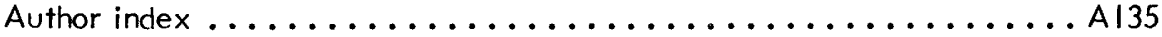




\section{ILLUSTRATIONS}

FIGURE 1. Chart showing major geochronologic and chrono-

PAGE stratigraphic units by Geologic Names Committee, 1980 edition

2. Index map of eastern Connecticut and adjacent Rhode Island and Massachusetts showing structural features.

3. Correlation chart of some stratigraphic units in southeastern Connecticut, eastern Massachusetts, and northern Rhode Island ...................... . . . A98

4. Index map of south-central Kentucky showing location of the Jabez Sandstone and Krifély Sandstone Members of the Fort Payne Formation

5. Diagrammatic cross section illustrating stratigraphic relationships and nomenclature of the Jabez Sandstone Member

6. Geologic sketch map of the Charleston, S. C., area showing the Wando Formation

7. Diagram of type (composite) and reference section of the Wando Formation

8. Map of eastern Kentucky showing the distribution of the open-bdy and marginal-bay facies of the Kendrick Shale Member of the Breathitt Formation ............. All8

9. Generalized geologic map of southwestern Massachusetts and north-central Connecticut showing the distribution of members and map units of the Cobble Mountain

Formation

10. Chart showing revised subdivision of the Cobble Mountain Formation

\section{TABLES}

TABLE I. Changes in nomenclature and age assignments, New London area, Connecticut, and Adjacent Rhode Island ..... A94-A95 


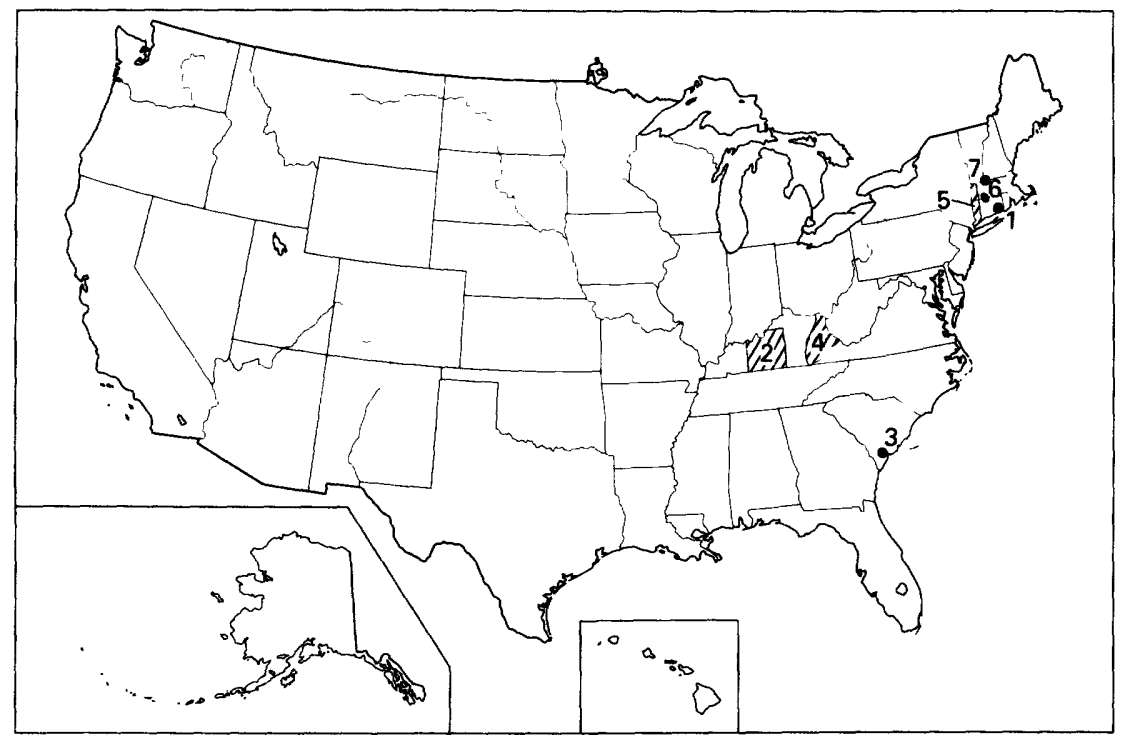

\section{GEOGRAPHIC INDEX TO ARTICLES}

1. Stratigraphic names, New London area, southeastern Connecticut. p. A 91

2. Jabez Sandstone Member of Fort Payne Formation, south-central Kentucky, p. A 104

3. Wando Formation, Charleston, S. C. area, p. A 110

4. Kendrick Shale Member of Breathitt Formation, eastern Kentucky, p. A 117

5. Collinsville Formation and its members, western Connecticut and western Massachusetts, p. A 123

6. Cobble Mountain Formation, southwestern Massachusetts and north-central Connecticut, p. A 127

7. Putney Volcanics, southeastern Vermont and north-central Massachusetts, p. A 133 



\title{
CHANGES IN STRATIGRAPHIC NOMENCLATURE \\ BY THE U.S. GEOLOGICAL SURVEY, 1979
}

\author{
By Norman F. Sohl and Wilna B. Wright
}

\section{NEW GEOLOGIC TIME CHART}

A revision of the geologic time chart "MAJOR GEOCHRONOLOGIC AND CHRONOSTRATIGRAPHIC UNITS" (fig. I), is being made available to U.S. Geological Survey geologists. It supersedes the 1972 chart compiled by the Geologic Names Committee, U.S. Geological Survey.

This new compilation was prepared by a committee chaired by Zell Peterman and consisting of Glen Izett, Marvin Lanphere, Majorie MacLachlan, Charles Naesor, John Obradovich, Meyer Rubin, Thomas Stern, and Robert Zartman.

The chart (fig. 1) includes key references generally accepted for the age estimates of time boundaries. 


\begin{tabular}{|c|c|c|c|c|c|c|}
\hline \multicolumn{5}{|c|}{$\begin{array}{l}\text { Subdivisions in use by the } \mathrm{U} S \text { Geolog } \\
\text { land their map symbolsl }\end{array}$} & \multicolumn{2}{|c|}{$\begin{array}{l}\text { Age estimates } 1{ }^{1} \cdot J_{0} \\
\text { boundaries in } \\
\text { million years }(\mathrm{m} y)\end{array}$} \\
\hline \multirow{18}{*}{$\begin{array}{c}\text { Phanerozoic } \\
\text { Eon or } \\
\text { Eonothem }\end{array}$} & \multirow{7}{*}{$\begin{array}{c}\text { Cenozoic } \\
\text { Era or } \\
\text { Erathem } \\
|\mathrm{Cz}|\end{array}$} & \multirow{2}{*}{\multicolumn{2}{|c|}{$\begin{array}{l}\text { Quaternary } \\
\text { Period or System } \\
\text { |Q| }\end{array}$}} & Holocene Epoch or Series & \multirow{2}{*}{$\begin{array}{l}-0010 \\
-2\end{array}$} & \multirow{2}{*}{-} \\
\hline & & & & Plesstocene Epoch or Serres & & \\
\hline & & \multirow{5}{*}{$\begin{array}{l}\text { Teniary } \\
\text { Period or } \\
\text { System } \\
\text { III }\end{array}$} & \multirow{2}{*}{$\begin{array}{c}\text { Neogene } \\
\text { Subperiod of } \\
\text { Subsystem } \\
\text { INI }\end{array}$} & Pliocene Epoch or Series & & $117.221-$ \\
\hline & & & & Miocene Epoch or Series & & \\
\hline & & & Paleogene & Oligocene Epoch or Series & & \\
\hline & & & Subperiod or & Eocene Epoch or Serres & 18 & \\
\hline & & & $\begin{array}{l}\text { Suosystem } \\
\left|P_{\varepsilon}\right|\end{array}$ & Paleocene Epoch or Series & -55 & $|54.56|-$ \\
\hline & & & & $\begin{array}{l}\text { Late Cretaceous Epoch or } \\
\text { Upper Cretaceous Series }\end{array}$ & -63 & $|63.66|=$ \\
\hline & $\begin{array}{l}\text { Mesozoic } \\
\text { Era or }\end{array}$ & or Sys & $n|K|$ & $\begin{array}{l}\text { Early Cretaceous Epoch or } \\
\text { Lower Cretaceous Series }\end{array}$ & .96 & $(95.97)-$ \\
\hline & (Mn) & Jurassic $P$ e & or System (J) & & -138 & $1135-1411-$ \\
\hline & & Friassic Per & or System $1 k$ & & -205 & $1200 \cdot 2151-$ \\
\hline & & Permian Per & or System IP & & $-\sim 240$ & - \\
\hline & & Carbonifer & $\begin{array}{c}\text { Pennsy } \\
\text { Syste }\end{array}$ & $\begin{array}{l}\text { Ivanian Period or } \\
m|P|\end{array}$ & -290 & $1290.3051-$ \\
\hline & Paleozoic & $\begin{array}{l}\text { Periods } \\
\text { Systems }\end{array}$ & \begin{tabular}{|c|} 
Missis \\
Syste
\end{tabular} & $\begin{array}{l}\text { ippian Period or } \\
(M)\end{array}$ & & \\
\hline & Era or & Devonian $P$ & or System 1 & & & \\
\hline & $\mid P z)$ & Silurian Per & or System IS & & & $1405.4151=$ \\
\hline & & Ordovician & lod or System & & & $1435.4401-$ \\
\hline & & Cambrian $P$ & od of System & & -500 & $1495-510 \mid-$ \\
\hline & Proterozorc & $21^{3}$ & & & & \\
\hline $\begin{array}{c}\text { Proterozoic } \\
\text { Eon or }\end{array}$ & Proterozoic & $\left.y\right|^{3}$ & & & & \\
\hline Eonothem IEl & Proterozoic & $|x|^{3-1}$ & & & & \\
\hline $\begin{array}{l}\text { Archean } \\
\text { Eon or } \\
\text { Eonothem } \\
\text { (A) }\end{array}$ & & & & known & $-3,600$ & - \\
\hline
\end{tabular}

$1 /$ Ranges reflect uncertainties of isotopic and biostratıgraphic age assignments. Age of boundaries not closely bracketed by existing data shown by Decay constants and isotope ratıos employed are cited in Steiger and Jager (1977).

$\frac{2}{3} /$ Rocks older than $570 \mathrm{~m}$ y. also called Precambrian (p€), a time term without specific rank.

$3 /$ Time terms without specific rank.

4. This chart was prepared by G A. Izett. M. A Lanphere. M. E. MacLachlan, C. W. Naeser, J D Obradovich, Z. E. Peterman, M. Rubin, T W. Stern, and R E Zartman at the request of the Geologic Names Committee. The chart is intended for use by members of the U.S. Geological Survey and does not constitute a formal proposal for a geologic time scale. Estımates of ages of boundarles were made after reviewing published time scales and other data Future modification of this chart will undoubtedly be required The general references apply where references are not given for specific boundaries.

Figure 1.--Major geochronologic and chronostratigraphic 


\section{General referances}

American Association of Petroleum Geologists, 1978, Studies in Geology 6, $388 \mathrm{p}$.

Berggren, W. A., 1972, Lethaia, v. 5, no. 2, p. 195-215. Evernden, J. F., Savage, D. E., Curtis, G. H., and James, G. T., 1964, American Journal of Science, v. 262, p. 145-198.

Geological Society of London, 1964, Quarterly Journal, v. $120 S, 458 p$.

Lambert, R. S., 1971, Geological Society of London, Special Publications 3, Part 1, p. 9-31.

Steiger, R. H., and Jager, E., 1977, Earth and Planetary Science Letters, v. 36 , p. 359-362.

\section{Holacene-Pleistecene boundary}

Hopkins, D. M., 1975, Geology, v. 3, p. 10.

\section{Pleistecene-Pliocene beundary}

Haq, B. U., Berggren, W. A., and Van Couvering, J. A. 1977. Nature, v. 269, p. 483-488.

Selli, R., Accorsi, C. A., Bandini, M. M., Bertolani, M. D., Bigazzi, G., Bonadonna, F. P., Borsetti, A. M., Cati, F. Colalongo, M. L.. D'onofrio, S., Landini, $W$. Menesini, E., Mezzetti, R., Pasini, G., Savelli, C., and Tampieri, R., 1977, Giornale di Geologica Bologna, ser. 2 , v. 42, no. 1, book II, p. 181-204.

\section{Pliocene-Miocene beundery}

Cita, M. B., 1975, Micropaleontology, Special Publication 1, 1-30.

McDougall, I., and Page, R. W., 1975 Micropaleontology Special Publication 1, p. 75-84. Tongiorgi, E., and Tongiorgi, M., 1964, Nature, v. 201, p. 365-367.

Van Couvering, J. A., 1972, in Bishop, W. W., and Milier, J. A,, eds., Calibration of hominid evolution, Scottish Academic Press and University of Toronto Press, p. 247-271.

\section{Miecene-Dligecene beundary}

Van Couvering, J. A., 1978, Geology, v. 6, p. 169 Van Couvering, J. A., and Berggren, W. A., 1977, in Kauffman, E. G., and Hazel, J. E., eds., Concepts and methods of biostratigraphy, Stroudsburg, $\mathrm{Pa}$. Dowden, Hutchinson, \& Ross New York; exclusive distributor: Halstead Press, c. 1977.

\section{Oligecene-Eecene beundary}

Hardenbol, J., and Berggren, W. A., 1978, American Association of Petroleum Geologists Studies in Geology 6, p. 213-234.

Odin, G. S., Curry, D., and Hunziker, J. C., 1978, Journal of the Geological Society of London, v. 135, p. $481-497$.

\section{Eacene-Paleecene beundery}

Berggren, W. A. McKenna, M. C., Hardenbol, J., and Obradovich, J. D., 1978, Journal of Geology, v. 86, p. $67-81$.

Fitch, F. J., Hooker, P. J., Miller, J. A., and Brereton, N. R., 1978, Journal of the Geological Society of London, v. 135, p. 499-512.

Odin, G. S., Curry, D., and Hunziker, J. C., 1978, Journal of the Geological Society of London, v. 135, p. $481-497$.

\section{Paleocene-Cretaceous baundery}

Lerbekmo, J. F., Evans, M. E., and Baadsgaard, H. 1979, Nature, v. 279, p. 26-30.

Obradovich, J. D., and Cobban, W. A., 1975, Geological Association of Canada Special Paper 13, p. 31-54.

\section{Late-Early Creteceous baundary}

Folinsbee, R. E., Baadsgaard, H., and Cumming, G. L., 1963, National Research Council Publication 1075, p. 70-82.

Obradovich, J. D., and Cobban, W. A., 1970, Geological Association of Canada Special Paper 13, p. 31-54.

\section{Cretacaous-Jurassic beundary}

Lanphere, M. A., and Jones, D. L., 1978, American Association of Petroleum Geologists Studies in Geology 6, p. 259-268.

\section{Jurassic-Triassic boundary}

Armstrong, R. L., and Besancon, J., 1970, Eclogae Geologicae Helvetiae, v. 63, no. 1, p. 15-28.

White, W. H., Erickson, G. P., Northcote, K. E., Dirom, G. E., and Harakal, J. E., 1967, Canadian Journal of Earth Sciences, v. 4, p. 677-690.

\section{Triassic-Permian beundery}

Webb, A. W., and McDougall, I., 1967, Earth and Planetary Science Letters 2, p. 483-488.

\section{Permian-Carbeniferous beundery}

Fitch, F. J., Miller, J. A., and Williams, S. C., 1970 International Congress on Stratigraphy and Carboniferous Geology, 6th, Sheffield, 1967. Compte Rendu, v. 2, p. 771-789.

\section{Corbeniferous-Devonian baundary}

Fitch, F. J., Miller, J. A., and Williams, S. C., 1970, International Congress on Stratigraphy and Carboniferous Geology, 6th, Sheffield, 1967. Compte Rendu, v. 2, p. 771-789.

McDougall, I., Compston, W., and Bofinger, V. M. 1966, Geological Society of America Bulletin, v. 77, p. 1075-1088.

Talent, J. A., 1975, in Boucot, A. J., Evolution and extinction rate controls, Amsterdam; New York: Elsevier Scientific Pub. Co., p. 63.

\section{Devenian-silurien beundary}

Ross, R. J., Jr., Naeser, C. W. Izett, G. A., Whittington, H. B., Hughes, C. P., Rickards, R. B., Zalasiewicz, J., Sheldon, P. R., Jenkins, C. J., Cocks, L. R. M., Bassett, M. G., Toghill, P., Dean, W. T., and Ingham, J. K., 1978 , U.S. Geological Survey Open-File Report 78-701, p. 363-365.

\section{Silurian-Ordovician beundnry}

Lanphere, M. A., Churkin, M., Jr, and Eberlein, G. D. 1977, Geological Magnzine, v. 114, no. 1, p. 15-24.

Ross, R. J., Jr., Naeser, C. W., Izett, G. A., Whittington, $H$. B., Hughes, C. P., Rickards, R. B., Zalasiewicz, J. Sheldon, P. R., Jenkins, C. J., Cocks, L. R. M., Bassett, M. G., Toghill, P., Dean, W. T., and Ingham, J. K., 1978 , U.S. Geological Survey Open-File Report $78-701$, p. 363-365.

\section{Preterazeic subdivisions}

James, H. L., 1972, American Association of Petroleum Geologists Bulletin, v. 56, p. 1128-1133.

Preterozoic-Archean beundary

James, H. L., 1978, Precambrian Research, v. 7, no. 3, p. 193-204.

\section{Archean}

Goldich, S. S., and Wooden, J. L., 1978, in Smith, I. E. M., and Williams, J. G., eds,, Proceedings of the 1978 Archean Geochemistry Conference, p. 285-318.

units by Geologic Names Committee, 1980 edition. 


\section{LISTING OF NOMENCLATURAL CHANGES}

In the following listing, stratigraphic names adopted, revised, reinstated, or abandoned are listed alphabetically. The time-stratigraphic classification (system or series) of the rock-stratigraphic unit, the area involved, and the action taken, along with the reference citation of the author(s), are given. The capitalization of terms follows official rockstratigraphic and time usage.

Adamstown Member (name adopted)

(of Frederick Limestone)

Upper Cambrian (Franconian)

Frederick Valley, western Maryland

Reinhardt, Juergen, 1977, Cambrian off-shelf sedimentation, central Appalachians: Society of Economic Paleontologists and Mineralogists Special Publication 25, p. 83-1/2.

Adamstown Member of Reinhardt (1974) adopted as middle of three members of Frederick Limestone. Overlies Rocky Springs Station Member of Frederick; underlies Lime Kiln Member of Frederick.

Amsden Formation (lithology of member changed) Upper Mississippian to Middle Pennsylvanian (varies) central Wyoming

Thaden, R. E., 1980, Geologic map of the Guffy Peak quadrangle, showing chromolithofacies in the Wind River Formation, Fremont and Hot Springs Counties, Wyoming: U.S. Geological Survey Geologic Quadrangle Map GQ1527.

In Guffy Peak and De Pass quadrangles of central Wyoming, lithology of Amsden's Ranchester Limestone Member changed to: Ranchester Dolomite Member. Ranchester's lithology remains unchanged elsewhere in Wyoming. Amsden Formation or Group remains in good usage elsewhere in Wyoming and in Montana and Idaho.

Andover Granite (age changed)

Silurian or Ordovician

northeastern Massachusetts

Goldsmith, Richard, Stratigraphic names in the New London area, southeastern Connecticut: a revision: this report.

Age changed from Precambrian(?) to Silurian(?) to: Silurian or Ordovician. 


\section{Apex Conglomerate (age changed) lower middle Oligocene central Utah}

Morris, H. T., and Lovering, T. S., 1979, General geology and mines of the East Tintic mining district, Utah and Juab Counties, Utah: U.S. Geological Survey Professional Paper 1024, 203 p.

Age changed from Eocene(?) to: early middle Oligocene.

\section{Araby Formation (name adopted) \\ Lower and Middle Cambrian \\ Frederick Valley, western Maryland}

Reinhardt, Juergen, 1977, Cambrian off-shelf sedimentation, central Appalachians: Society of Economic Paleontologists and Mineralogists Special Publication 25, p. 83-112.

Araby Formation of Reinhardt (1974) adopted. Overlies ljamsville Phyllite or Harpers Formation; underlies Rocky Springs Station Member of Frederick Limestone.

\section{Arco Hills Formation (here named) Upper Mississippian (Chesterian) east-central Idaho}

Skipp, Betty, Hoggan, R. D., Schleicher, D. L., and Douglass, R. C., 1979, Upper Paleozoic carbonate bank in east-central Idaho--Snaky Canyon, Bluebird Mountain, and Arco Hills Formations and their paleotectonic significance: U.S. Geological Survey Bulletin 1486, 78 p.

Arco Hills Formation adopted. Gradationally overlies Surrett Canyon Formation; gradationally or unconformably underlies Bluebird Mountain Formation (new name).

\section{Artillery Formation (age changed)}

lower Miocene

west-central Arizona

Otton, J. K., 1979, Geologic setting for uranium deposits in the Date Creek basin, west-central Arizona, in Geological Survey research 1979: U.S. Geological Survey Professional Paper II50, p. 43.

Age changed from early Eocene(?) to: early Miocene.

Ashley Member (name adopted)

(of Cooper Formation)

upper Oligocene

southern South Carolina 
Ward, L. W., Blackwelder, B. W., Gohn, G. S., and Poore, R. Z., 1979, Stratigraphic revision of Eocene, Oligocene, and lower Miocene formations of South Carolina: South Carolina Division of Geology Geologic Notes, v. 23, no. 1, p. 2-32.

Cooper Formation divided into (ascending): Harleyville (new name), Parkers Ferry (new name), and Ashley (loosely defined as "Ashley marl" by Tuomey, 1848, and Sloan, 1908) Members. Ashley overlies Parkers Ferry or Harleyville Member of Cooper and underlies Pliocene(?) or Pleistocene(?) arenaceous sands; probably correlates with River Bend Formation of southeastern North Carolina.

Asotin Member (here named)

(of Saddle Mountains Basalt)

(of Yakima Basalt Subgroup)

(of Columbia River Basalt Group)

middle Miocene

southeastern Washington and northwestern Idaho

Swanson, D. A., Wright, T. L., Hooper, P. R., and Bentley, R. D., 1979, Revisions in stratigraphic nomenclature of the Columbia River Basalt Group: U.S. Geological Survey Bulletin 1457-G, 59 p.

Asotin Member adopted and assigned as one of ten members to Saddle Mountains Basalt (now redefined) of Yakima Basalt Subgroup (now raised in rank) of Columbia River Basalt Group (now redefined). Unconformably overlies Wilbur Creek Member and conformably underlies Weissenfels Ridge Member (both new names) of Saddle Mountains.

\section{Beacon Hill Gravel (age changed) \\ Miocene \\ New Jersey and Pennsylvania}

Owens, J. P., and Minard, J. P., 1979, Upper Cenozoic sediments of the lower Delaware Valley and the northern Delmarva Peninsula, New Jersey, Pennsylvania, and Maryland, Chapter D in Surface and shallow subsurface geologic studies in the emerged Coastal PTain of the Middle Atlantic states: U.S. Geological Survey Professional Paper 1067-D, 47 p.

Age changed from Pliocene(?) to: Miocene (older than Pensauken, upper Miocene, and Bridgeton, Miocene).

\section{Bear Bluff Formation (name adopted)}

upper Pliocene

east-central South Carolina and southeastern North Carolina

Blackwelder, B. W., and Ward, L. W., 1979, Stratigraphic revision of the Pliocene deposits of North and South Carolina: South Carolina Division of Geology Geologic Notes, v. 23, no. 1, p. 33-49. 
Bear Bluff Formation of DuBar (1969) and DuBar and others (1974) adopted. Unconformably overlies Peedee Formation; unconformably underlies Canepatch or Waccamaw Formation.

Belkofski Formation (lithology changed and age refined) Oligocene

Alaska Peninsula

McLean, Hugh, 1979, Teftiary stratigraphy and petroleum potential of the Cold Bay-False Pass direa, Alaska Peninsula: American Association of Petroleum Geologists Bulletin, v. 63, no. 9, p. 1522-1526.

Lithology changed from Belkofski Tuff to: Belkofski Formation. Age refined from middle Tertiary to: Oligocene.

\author{
Beverly Member (age changed) \\ (of Ellensburg Formation) \\ middle Miocene \\ Washington
}

Swanson, D. A., Wright, T. L., Hooper, P. R., and Bentley, R. D., 1979, Revisions in stratigraphic nomenclature of the Columbia River Basalt Group: U.S. Geological Survey Bulletin 1457-G, 59 p.

Age changed from late Miocene and early Pliocene to: middle Miocene.

\title{
Big Canyon Latite (here named)
}

(of Tintic Mountain Volcanic Group)

middle Oligocene

central Utah

Morris, H. T., and Lovering, T. S., 1979, General geology and mines of the East Tintic mining district, Utah and Juab Counties, Utah: U.S. Geological Survey Professional Paper 1024, 203 p.

Big Canyon Latite adopted and assigned to Tintic Mountain Volcanic Group (new name) as uppermost of three formations. Divided into (ascending): unnamed tuff member and unnamed flow member. Unconformably overlies Latite Ridge Latite (new name) of Tintic Mountain; unconformably underlies North Standard Latite (new name) of Laguna Springs Volcanic Group (now raised in rank).

Big Stone Gap Member (geographic extension)

(of Chattanooga Shale)

Upper Devonian and Lower Mississippian

northeastern Tennessee

Kepferle, R. C., 1979, Delta front of the Borden Formation in central Kentucky, in Ettensohn, F. R., and Dever, G. R., Jr., editors, Carboniferous geology from the Appalachian basin to the Illino is basin through eastern Ohio 
and Kentucky: International Congress of Carboniferous Geology and Stratigraphy, 9th, Urbana, Illinois, 1979, Field Trip 4, p. 239-253

Geographically extended from southwestern Virginia into: northeastern Tennessee.

Blackstone Group (name and age changed)

Proterozoic Z

Rhode Island

Goldsmith, Richard, Stratigraphic names in the New London area, southeastern Connecticut: a revision: this report.

Name changed from Blackstone Series to: Blackstone Group. Age of Blackstone and its four formations (Mussey Brook, Quinnville, Sneech Pond, Hunting Hill) changed from Precambrian(?) to: Proterozoic Z.

\section{Bloom Member (here named)}

(of Snaky Canyon Formation)

uppermost Mississippian (locally) to Upper Pennsylvanian

east-central Idaho

Skipp, Betty, Hoggan, R. D., Schleicher, D. L., and Douglass, R. C., 1979, Upper Paleozoic carbonate bank in east-central Idaho--Snaky Canyon, Bluebird Mountain, and Arco Hills Formations and their paleotectonic significance: U.S. Geological Survey Bulletin 1486, 78 p.

Bloom Member adopted and assigned to Snaky Canyon Formation (new name) as its lowermost of three named members. Gradationally overlies Bluebird Mountain Formation (new name); gradationally underlies Gallagher Peak Sandstone Member (new name) of Snaky Canyon.

\section{Bluebird Mountain Formation (here named) \\ Upper Mississippian (Chesterian) \\ east-central Idaho}

Skipp, Betty, Hoggan, R. D., Schleicher, D. L., and Douglass, R. C., 1979, Upper Paleozoic carbonate bank in east-central Idaho--Snaky Canyon, Bluebird Mountain, and Arco Hills Formations and their paleotectonic significance: U.S. Geological Survey Bulletin 1486, 78 p.

Bluebird Mountain Formation adopted. Gradationally or unconformably overlies Arco Hills Formation (new name), Surrett Canyon Formation, or Big Snowy Formation (at type section); gradationally underlies Bloom Member of Snaky Canyon Formation (both new names). 
Blue Lake Rhyolite Member (here named)

(of Mount Belknap Volcanics)

Miocene

west-central Utah

Cunningham, C. G., and Steven, T. A., 1979, Mount Belknap and Red Hills calderas and associated rocks, Marysvale volcanic field, west-central Utah: U.S. Geological Survey Bulletin 1468, 34 p.

Blue Lake Rhyolite Member adopted as one of five members of Mount Belknap Volcanics in Mount Belknap caldera. Overlies unnamed lower tuff member and underlies unnamed middle tuff member (both of Mount Belknap).

\section{Boxford Member (age changed) \\ (of Nashoba Formation) \\ Ordovician or Proterozoic Z \\ northeastern Massachusetts}

Goldsmith, Richard, Stratigraphic names in the New London area, southeastern Connecticut: a revision: this report.

Age of Nashoba and its Boxford Member (and by inference its other nine members: Bellows Hill, Billerica, Spencer Brook, Tophet Swamp, Nashoba Brook, Nagog Pond, Fort Pond, Long Pond, and Beaver Brook) changed from pre-Silurian to: Ordovician or Proterozoic Z.

\section{Brandywine Formation (age changed) Miocene Maryland}

Owens, J. P., and Denny, C. S., 1979, Upper Cenozoic deposits of the central Delmarva Peninsula, Delaware and Maryland, Chapter A in Surface and shallow subsurface geologic studies in the emerged Coastal Plain of the Middle Atlantic states: U.S. Geological Survey Professional Paper 1067-A, $28 \mathrm{p}$.

Age changed from Pliocene(?) to: Miocene (older than Pensauken, upper Miocene, and Bridgeton, Miocene). Brandywine Formation or Gravel remains good usage in Delaware, Virginia, North Carolina, and South Carolina.

\section{Breathitt Formation (member assigned to) \\ Lower and Middle Pennsylvanian \\ eastern Kentucky}

Rice, C. L., Kendrick Shale Member of the Breathitt Formation in eastern Kentucky: this report.

Kendrick Shale of Jillson (1919) adopted, redefined as Kendrick Shale Member, and assigned to middle part of Breathitt Formation, overlying Williamson (Amburgy) coal bed or coal zone and underlying Whitesburg coal zone. Age of Kendrick is Middle Pennsylvanian (Morrowan). Usage of 
Breathitt Formation or Group remains unchanged elsewhere in Kentucky and in Virginia and Tennessee.

\title{
Bridgeton Formation (age changed) \\ Miocene \\ New Jersey and Pennsylvania
}

Owens, J. P., and Minard, J. P., 1979, Upper Cenozoic sediments of the lower Delaware Valley and the northern Delmarva Peninsula, New Jersey, Pennsylvania, and Maryland, Chapter D in Surface and shallow subsurface geologic studies in the emerged Coastal Plain of the Middle Atlantic states: U.S. Geological Survey Professional Paper 1067-D, 47 p.

Age changed from early Pleistocene to: Miocene (older than Pensauken, upper Miocene).

\section{Brimfield Schist (geographic restriction) \\ Middle(?) Ordovician or older \\ New London area of southeastern Connecticut}

Goldsmith, Richard, Stratigraphic names in the New London area, southeastern Connecticut: a revision: this report.

Geographically restricted from New London area of southeastern Connecticut; replaced by informal name: schist in Hunts Brook. Brimfield Schist or Group remains good usage elsewhere in Connecticut and in Massachusetts and New Hampshire.

\author{
Bristol Member (name adopted) \\ (of Collinsville Formation) \\ Middle Ordovician or older \\ north-central Connecticut and western Massachusetts
}

Stanley, R. S., 1980, Adoption, redefinition, and extended use of the name Collinsville Formation and its members and related formations in Connecticut and Massachusetts: this report.

Bristol granite gneiss of Rice and Gregory (1906) adopted and redefined as Bristol Member, lower of two named members of Collinsville Formation as used by Stanley (1964). Correlated with lower part of Cobble Mountain Formation; overlies Taine Mountain Formation; underlies Sweetheart Mountain Member of Collinsville.

\section{Buford Member (name adopted)}

(of Saddle Mountains Basalt)

(of Yakima Basalt Subgroup)

(of Columbia River Basalt Group)

upper Miocene

northeastern Oregon and southwestern Washington 
Swanson, D. A., Wright, T. L., Hooper, P. R., and Bentley, R. D., 1979, Revisions in stratigraphic nomenclature of the Columbia River Basalt Group: U.S. Geological Survey Bulletin 1457-G, 59 p.

Buford flow of Walker (1973) formalized and adopted as Buford Member, one of ten members assigned to Saddle Mountains Basalt (now redefined) of Yakima Basalt Subgroup (now raised in rank) of Columbia River Basalt Group (now redefined). Conformably overlies Elephant Mountain Member (now redefined) of Saddle Mountains; believed to predate Ice Harbor (newly adopted) and Lower Monumental (new name) Members of Saddle Mountains.

\section{Bull Fork Formation (geographic extension)}

Upper Ordovician

north-central Kentucky and southwestern Ohio

Pojeta, John, Jr., 1979, The Ordovician paleontology of Kentucky and nearby states--introduction: U.S. Geological Survey Professional Paper 1066-A, 48 p.

Geographically extended from north-central Kentucky into: southwestern Ohio.

\section{Bullion Canyon Volcanics (subdivided and age changed)} Oligocene and Miocene Utah

Steven, T. A., Cunningham, C. G., Naeser, C. W., and Mehnert, H. H., 1979, Revised stratigraphy and radiometric ages of volcanic rocks and mineral deposits in the Marysvale area, west-central Utah: U.S. Geological Survey Bulletin 1469, 40 p.

Divided into (ascending): unnamed lower part (Oligocene), Three Creeks Tuff Member (new name; Oligocene), unnamed upper part (Miocene), and Delano Peak Tuff Member (Miocene). Replaces Dry Hollow Formation (now abandoned) in many areas. Age changed from Oligocene and Miocene(?) to: Oligocene and Miocene.

\section{Burlington Formation (age changed)}

Proterozoic Z

northeastern Massachusetts

Goldsmith, Richard, Stratigraphic names in the New London area, southeastern Connecticut: a revision: this report.

Age changed from pre-Silurian (late Precambrian? to Ordovician?) to: Proterozoic Z. 
Calabasas Formation (here named)

(of Topanga Group)

middle Miocene

southern California

Yerkes, R. F., and Campbell, R. H., 1979, Stratigraphic nomenclature of the central Santa Monica Mountains, Los Angeles County, California: U.S. Geological Survey Bulletin 1457-E, 31 p.

Calabasas Formation adopted as uppermost of three formations of Topanga Group. Includes (ascending): Dry Canyon Sandstone, Escondido Canyon Shale, Latigo Canyon Breccia, Newell Sandstone, Mesa Peak Breccia, and Stokes Canyon Breccia Members (all new names). Conformably(?) overlies and locally intertongues with Conejo Volcanics of Topanga; unconformably underlies Modelo Formation.

Canaan Mountain Formation (name adopted) upper Precambrian(?) to Lower Cambrian northwestern Connecticut

Harwood, D. S., 1979, Bedrock geologic map of the Norfolk Quadrangle, Connecticut: U.S. Geological Survey Geologic Quadrangle Map GQ-1518.

Canaan Mountain Schist of Rodgers and others (1956, 1959) adopted as Canaan Mountain Formation as redefined by Gates (1975). In thrust contact with Stockbridge and Walloomsac Formations and some unnamed Precambrian gneiss; underlies Waramaug Formation to north and west in thrust contact.

\section{Conyon Mountain Complex (age changed)}

Lower Permian

northeastern Oregon

Thayer, T. P., 1977, The Canyon Mountain Complex, Oregon, and some problems of ophiolites, in Coleman, R. G., and Irwin, W. P., editors, North American ophiolites: Oregon Department of Geology and Mineral Industries Bulletin 95, p. 93-105.

Age changed from pre-Permian(?) to: Early Permian.

Carbondale Formation (geographic extension)

(of Kewanee Group in Illinois and Indiana only)

Middle Pennsylvanian

Illinois and Indiana

Solem, Alan, and Yochelson, E. L., 1979, North American Paleozoic land snails, with a summary of other Paleozoic nonmarine snails: U.S. Geological Survey Professional Paper 1072, 42 p.

Geographically extended from Illinois and Kentucky into Indiana. 
Carrara Formation (subdivided)

Lower and Middle Cambrian

southern Nevada and southeastern California

Palmer, A. R., and Halley, R. B., 1979, Physical stratigraphy and trilobite biostratigraphy of the Carrara Formation (Lower and Middle Cambrian), southern Great Basin: U.S. Geological Survey Professional Paper 1047, 131 p.

Divided into (ascending): Eagle Mountain Shale Member, Thimble Limestone Member, Echo Shale Member, Gold Ace Limestone Member, Pyramid Shale Member, Red Pass Limestone Member, Pahrump Hills Shale Member, Jangle Limestone Member, Desert Range Limestone Member (all nine new names except Jangle; all appear conformable). Pyramid contains Lower-Middle Cambrian boundary.

Cathedral Peak Granodiorite (lithology changed and age refined)

(of Tuolumne Intrusive Series)

lower Upper Cretaceous

central California

Bateman, P. C., and Chappell, B. W., 1979, Crystallization, fractionation, and solidification of the Tuolumne Intrusive Series, Yosemite National Park, California: Geological Society of America Bulletin, Part 1, v. 90, no. 5, p. 465-482.

Lithology changed from Cathedral Peak Granite to: Cathedral Peak Granodiorite. Age refined from Cretaceous to: early Late Cretaceous.

\section{Cedar Bay Granite (age changed) \\ Eocene(?) \\ south-central Alaska}

Tysdal, R. G., and Case, J. E., 1979, Geologic map of the Seward and Blyling Sound Quadrangles, Alaska: U.S. Geological Survey Miscellaneous Investigations Series Map I-1150, 12 p. text.

Age changed from Mesozoic(?) to: Eocene(?).

Challis Volcanics (age changed)

Paleocene(?) and Eocene

eastern Idaho and southwestern Montana

Staatz, M. H., 1979, Geology and mineral resources of the Lemhi Pass thorium district, Idaho and Montana: U.S. Geological Survey Professional Paper 1049-A, 90 p.

Age changed from Paleocene(?), Eocene(?), Oligocene, and Miocene(?) to: Paleocene(?) and Eocene. 
Chapin Wash Formation (age changed)

lower Miocene

west-central Arizona

Otton, J. K., 1979, Geologic setting for uranium deposits in the Date Creek basin, west-central Arizona, in Geological Survey research 1979: U.S. Geological Survey Professional Paper II50, p. 43.

Age changed from late early to middle Miocene(?) to: early Miocene.

Cherry Brook Formation (age changed)

Proterozoic Z

eastern Massachusetts

Goldsmith, Richard, Stratigraphic names in the New London area, southeastern Connecticut: a revision: this report.

Age changed from Precambrian Z to early Paleozoic(?) to: Proterozoic Z.

\section{Chico Formation (geographic restriction) \\ Upper Cretaceous \\ northern California}

Yerkes, R. F., and Campbell, R. H., 1979, Stratigraphic nomenclature of the central Santa Monica Mountains, Los Angeles County, California: U.S. Geological Survey Bulletin 1457-E, 31 p.

Geographically restricted from coastal southern California; its rocks replaced by Tuna Canyon Formation (new name) in Santa Monica Mountains.

Chilhowee Group (geographic extension)

uppermost Precambrian(?) to Lower Cambrian

Tennessee, Georgia, Virginia, West Virginia, Maryland,

Pennsylvania, and New Jersey

Harris, L. D., 1979, Similarities between the thick-skinned Blue Ridge anticlinorium and the thin-skinned Powell Valley anticline: Geological Society of America Bulletin, Part I, v. 90, no. 6, p. 525-539.

Geographically extended from Tennessee, Georgia, North Carolina, Virginia, West Virginia, Maryland, and Pennsylvania into: northern New Jersey in unit composed of Rome Formation, Shady Dolomite, Evington Group, and Chilhowee Group.

\section{Claypit Hill Formation (age changed)}

Proterozoic Z

eastern Massachusetts 
Goldsmith, Richard, Stratigraphic names in the New London area, southeastern Connecticut: a revision: this report.

Age changed from Precambrian $Z$ to early Paleozoic(?) to: Proterozoic $Z$.

\section{Clays Ferry Formation (geographic extension)}

Middle and Upper Ordovician

central and north-central Kentucky and

southeastern Indiana

Pojeta, John, Jr., 1979, The Ordovician paleontology of Kentucky and nearby states-introduction: U.S. Geological Survey Professional Paper 1066-A, 48 p.

Geographically extended from central and north-central Kentucky into: southeastern Indiana; its Point Pleasant Tongue geographically extended from north-central Kentucky into: southeastern Indiana.

\section{Coal Canyon Formation (here named)}

Paleocene and Eocene(?)

southern California

Yerkes, R. F., and Campbell, R. H., 1979, Stratigraphic nomenclature of the central Santa Monica Mountains, Los Angeles County, California: U.S. Geological Survey Bulletin 1457-E, 31 p.

Coal Canyon Formation adopted; replaces Martinez Formation (now geographically restricted) in Santa Monica Mountains in coastal southern California. Unconformably(?) overlies Tuna Canyon Formation (new name) or locally intervening Simi(?) Conglomerate; underlies Llajas(?) Formation.

Cobble Mountain Formation (redefined)

Middle Ordovician

southwestern Massachusetts and north-central Connecticut

Stanley, R. S., Knapp, D. A., and Hatch, N. L., Jr., Redefinition of the Cobble Mountain Formation in southwestern Massachusetts: this report.

Redefined from informal subdivision of lower and upper members to: informal subdivision of members $A$ (=former lower member), $B, C$, and $D$ (=former upper member). Upper part (members $C$ and D) geographically extended from southwestern Massachusetts into: north-central Connecticut.

\section{Cohansey Sand (age changed) \\ Miocene \\ New Jersey and Pennsylvania}


Owens, J. P., and Minard, J. P., 1979, Upper Cenozoic sediments of the lower Delaware Valley and the northern Delmarva Peninsula, New Jersey, Pennsylvania, and Maryland, Chapter D in Surface and shallow subsurface geologic studies in the emerged Coastal Plain of the Middle Atlantic states: U.S. Geological Survey Professional Paper 1067-D, 47 p.

Age changed from Miocene(?) and Pliocene(?) to: Miocene (older than Beacon Hill, Miocene; younger than Kirkwood, middle Miocene).

\author{
Cold Creek Member (here named) \\ (of Topanga Canyon Formation) \\ (of Topanga Group) \\ middle Miocene \\ southern California
}

Yerkes, R. F., and Campbell, R. H., 1979, Stratigraphic nomenclature of the central Santa Monica Mountains, Los Angeles County, California: U.S. Geological Survey Bulletin 1457-E, 31 p.

Cold Creek Member adopted as uppermost of three members of Topanga Canyon Formation (new name) of Topanga Group in area east of Malibu Canyon in southern Califomia. Conformably overlies Fernwood Member (new name) of Topanga Canyon; unconformably underlies Conejo Volcanics or Calabasas Formation (new name).

\title{
Collinsville Formation (name adopted) \\ Middle Ordovician or older \\ north-central Connecticut and western Massachusetts
}

Stanley, R. S., 1980, Adoption, redefinition, and extended use of the name Collinsville Formation and its members and related formations in Connecticut and Massachusetts: this report.

Collinsville granite gne iss of Rice and Gregory (1906) adopted and redefined as Collinsville Formation as used by Stanley (1964). Geographically extended from north-central Connecticut into: western Massachusetts. Divided into: Bristol Member grading into overlying Sweetheart Mountain Member. Correlated with Cobble Mountain Formation.

\section{Columbia River Basalt Group (redefined) \\ lower, middle, and upper Miocene northern Oregon, southern Washington, and northwestern Idaho}

Swanson, D. A., Wright, T. L., Hooper, P. R., and Bentley, R. D., 1979, Revisions in stratigraphic nomenclature of the Columbia River Basalt Group: U.S. Geological Survey Bulletin 1457-G, 59 p. 
Divided into (ascending): Imnaha Basalt (newly adopted), Picture Gorge Basalt, and Yakima Basalt Subgroup (now raised in rank), which includes Grande Ronde Basalt (newly adopted), Wanapum Basalt (new name) with its Eckler Mountains (new name), Frenchman Springs, Roza, and Priest Rapids (all three now redefined) Members, and Saddle Mountains Basalt (now redefined) with its Umatilla, (now redefined), Wilbur Creek (new name), Asotin (new name), Weissenfels Ridge (new name), Esquatzel (new name), Pomona (now redefined), Elephant Mountain (now redefined), Buford (newly adopted), Ice Harbor (newly adopted), and Lower Monumental (new name) Members. Age changed from middle Miocene through early Pliocene to: early, middle, and late Miocene.

Condrey Mountain Schist (here named)

Upper Jurassic

northern California and southwestern Oregon

Hotz, P. E., 1979, Regional metamorphism in the Condrey Mountain Quadrangle, north-central Klamath Mountains, California: U.S. Geological Survey Professional Paper 1086, 25 p.

Condrey Mountain Schist adopted as greenschist metamorphic facies bordered on east and west by rocks belonging to unnamed amphibolite metamorphic facies that structurally overlie and are thrust over Condrey Mountain Schist.

\section{Conejo Volcanics (assigned to group and subdivided) \\ (of Topanga Group) \\ middle Miocene \\ southern California}

Yerkes, R. F., and Campbell, R. H., 1979, Stratigraphic nomenclature of the central Santa Monica Mountains, Los Angeles County, California: U.S. Geological Survey Bulletin 1457-E, 31 p.

Assigned to Topanga Group (now raised in rank in central Santa Monica Mountains of southern California) as middle of three formations. Divided into (ascending): Ramera Canyon, Solstice Canyon, and Malibu Bowl Tongues (all new names). Overlies Topanga Canyon Formation (new name) of Topanga; interfingers with and underlies Calabasas Formation (new name) of Topanga.

\section{Cooper Formation (subdivided)}

upper Eocene and lower and upper Oligocene southern South Carolina

Ward, L. W., Blackwelder, B. W., Gohn, G. S., and Poore, R. Z., 1979, Stratigraphic revision of Eocene, Oligocene, and lower Miocene formations of South Carolina: South Carolina Division of Geology Geologic Notes, v. 23, no. 1, p. 2-32. 
In southern South Carolina, divided into (ascending): Harleyville (new name), Parkers Ferry (new name), and Ashley (loosely defined as "Ashley marl" by Tuomey, 1848, and Sloan, 1908) Members. Overlies Cross Member (new name) of Santee Limestone; underlies Pliocene(?) or Pleistocene(?) arenaceous sands. Cooper Marl or Formation remains good usage elsewhere in South Carolina and in Georgia. Age is late Eocene and early and late Eocene only in report area; over-all age remains late Eocene, early and late Oligocene, and early Miocene(?).

\title{
Coosamatchie Clay Member (name adopted)
}

(of Hawthorn Formation)

middle Miocene (Serravallian)

southeastern South Carolina and eastern Georgia

Abbott, W. H., and Andrews, G. W., 1979, Middle Miocene marine diatoms from the Hawthorn Formation of the Ridgeland Trough, South Carolina and Georgia: Micropaleontology, v. 25, no. 3, p. 225-27l.

Coosawhatchie Clay of Heron and others (1965) adopted as Coosawhatchie Clay Member of upper part of Hawthorn Formation following Johnson (1965). Correlates with upper half of Choptank Formation of Maryland.

\author{
Copperopolis Latite (here named) \\ (of Tintic Mountain Volcanic Group) \\ middle Oligocene \\ central Utah
}

Morris, H. T., and Lovering, T. S., 1979, General geology and mines of the East Tintic mining district, Utah and Juab Counties, Utah: U.S. Geological Survey Professional Paper 1024, 203 p.

Copperopolis Latite adopted and assigned to Tintic Mountain Volcanic Group (new name) as lowermost of three formations. Divided into three unnamed members. Unconformably overlies Packard Quartz Latite; unconformably underlies Latite Ridge Latite (new name) of Tintic Mountain.

\section{Cottonwood Canyon Member (geographic extension) \\ (of Lodgepole Limestone) \\ Lower Mississippian (Kinderhookian) northeastern Utah}

Sandberg, C. A., and Gutschick, R. C., 1979, Guide to conodont biostratigraphy of Upper Devonian and Mississippian rocks along the Wasatch front and Cordilleran hingeline, Utah, in Sandberg, C. A., and Clark, D. L., editors, Conodont biostratigraphy of the Great Basin and Rocky Mountains: Brigham Young University Geology Studies, v. 26, pt. 3, p. 107-133.

Cottonwood Canyon, basal member of Lodgepole Limestone, geographically extended from southern Montana into: northeastern Utah; age is Early 
Mississippian (Kinderhookian) only. Cottonwood Canyon Member of Madison Limestone of late Late Devonian and Early Mississippian age remains good usage in northern and west-central Wyoming.

Coys Hill Granite (geographic extension and age changed)

Lower Devonian

west-central Massachusetts and southwestern New Hampshire

Ashwal, L. D., Leo, G. W., Robinson, Peter, Zartman, R. E., and Hall, D. J., 1979, The Belchertown Quartz Monzodiorite pluton, west-central Massachusetts: A syntectonic Acadian intrusion: American Journal of Science, v. 279, no. 8, p. 936-969.

Geographically extended from west-central Massachusetts into: southwestern New Hampshire. Age changed from late Carboniferous or post-Carbonif erous to: Early Devonian.

\section{Cross Member (here named)}

(of Santee Limestone)

middle Eocene (upper Claibornian)

southern South Carolina

Ward, L. W., Blackwelder, B. W., Gohn, G. S., and Poore, R. Z., 1979, Stratigraphic revision of Eocene, Oligocene, and lower Miocene formations of South Carolina: South Carolina Division of Geology Geologic Notes, v. 23, no. I, p. 2-32.

Santee Limestone divided into (ascending): Moultrie and Cross Member (both new names). Cross correlates with Gosport Sand of Alabama and with Comfort and Spring Garden Members of Castle Hayne Formation in southeastern North Carolina. Unconformably over lies Moul trie Member (new name) of Santee and underlies Raysor Formation (now reinstated). at stratotype.

Curtis Member (redefined)

(of Stump Formation)

Middle Jurassic (Callovion)

central and northeastern Utah, southeastern Idaho, southwestern Wyoming, and northwesternmost Colorado

Pipiringos, G. N., and Imlay, R. W., 1979, Lithology and subdivisions of the Jurassic Stump Formation in southeastern Idaho and adjoining areas: U.S. Geological Survey Professional Paper 1035-C, 25 p.

Reduced in rank to Curt is Member, assigned as lower of two named members of Stump Formation, and geographically extended from central and northeastern Utah and northwesternmost Colorado into: southeastern Idaho and southwestern Wyoming (where Curtis not affiliated with San Rafael Group). Overlies Preuss Sandstone; underlies Redwater Member of Stump. Age of Curtis changed everywhere from Late Jurassic to: Middle Jurassic 
(Callovian). Usage of Curtis Formation of San Rafael Group remains unchanged elsewhere in Utah and Colorado.

Cushing Formation (age changed)

Proterozoic Z(?) or lower Paleozoic south-central Maine

Osberg, P. H., 1979, Geologic relationships in south-central Maine, in Skehan, J. S., and Osberg, P. H., editors, The Caledonides in the U.S.A.; Geological excursions in the northeast Appalachians--Contributions to the International Geological Correlation Program (IGCP), Project 27-Caledonide Orogen: Weston, Mass., Boston University, Weston Observatory, p. 37-62.

Age changed from early and middle Paleozoic to: Proterozoic Z(?) or early Paleozoic.

Danielson Member (name adopted)

(of Vaqueros Formation)

lower Miocene

southern California

Yerkes, R. F., and Campbell, R. H., 1979, Stratigraphic nomenclature of the central Santa Monica Mountains, Los Angeles County, California: U.S. Geological Survey Bulletin 1457-E, 31 p.

Danielson Formation of Sonneman (1956) adopted as Danielson Member of Vaqueros Formation. Conformably overlies(?) Sespe Formation; conformably under lies San Nicholas Member of Vaqueros.

\section{Decker Soil (here named) \\ Holocene \\ north-central Utah}

Van Horn, Richard, 1979, The Holocene Ridgeland Formation and associated Decker Soil (new names) near Great Salt Lake, Utah: U.S. Geological Survey Bulletin 1457-C, $11 \mathrm{p}$.

Decker Soil adopted. Formed on Ridgeland Formation (new name); normally uppermost deposit present.

Delano Peak Tuff Member (lithology and age changed)

(of Bullion Canyon Volcanics)

Miocene

Utah

Steven, T. A., Cunningham, C. G., Naeser, C. W., and Mehnert, H. H., 1979, Revised stratigraphy and radiometric ages of volcanic rocks and mineral deposits in the Marysvale area, west-central Utah: U.S. Geological Survey Bulletin 1469, $40 \mathrm{p}$. 
Lithology changed from Delano Peak Latite Member to: Delano Peak Tuff Member. Age changed from Miocene(?) to: Miocene.

\title{
Desert Range Limestone Member (here named) (of Carrara Formation) \\ Middle Cambrian \\ southern Nevada and southeastern California
}

Palmer, A. R., and Halley, R. B., 1979, Physical stratigraphy and trilobite biostratigraphy of the Carrara Formation (Lower and Middle Cambrian), southern Great Basin: U.S. Geological Survey Professional Paper 1047, 131 p.

Desert Range Limestone Member adopted as uppermost of nine named members of Carrara Formation. Overlies Jangle Limestone Member of Carrara; gradationally underlies Bonanza King Formation.

\section{Diamond Peak Formation (geographic extension)}

Lower Mississippian to Lower Pennsylvanian (varies locally) northwestern Utah

Moore, W. J., and Sorensen, M. L., 1979, Geologic map of the Tooele $1^{\circ}$ by $2^{\circ}$ Quadrangle, Utah: U.S. Geological Survey Miscellaneous Investigations Series Map 1-1132.

Geographically extended from Nevada into: northwestern Utah; former usage remains unchanged in Nevada.

\section{Dillsboro Formation (name adopted) \\ Upper Ordovician \\ southeastern Indiana}

Pojeta, John, Jr., 1979, The Ordovician paleontology of Kentucky and nearby states-introduction: U.S. Geological Survey Professional Paper 1066-A, 48 p.

Dillsboro Formation of Brown and Lineback (1966) adopted. Overlies Kope Formation; underlies Saluda Formation.

\author{
Dry Canyon Sandstone Member (here named) \\ (of Calabasas Formation) \\ (of Topanga Group) \\ middle Miocene \\ southern California
}

Yerkes, R. F., and Campbell, R. H., 1979, Stratigraphic nomenclature of the central Santa Monica Mountains, Los Angeles County, California: U.S. Geological Survey Bulletin 1457-E, 31 p.

Dry Canyon Sandstone Member adopted as lowermost of six new members of 
Calabasas Formation (new name) of Topanga Group. Overlies Ramera Canyon Tongue (new name) of Conejo Volcanics; underlies Newell Sandstone Member (new name) of Calabasas or Malibu Bowl Tongue of Conejo; tongues westward into Escondido Canyon Shale Member (new name) of Calabasas.

\section{Dry Hill Gneiss (lithology and age changed) upper Precambrian west-central Massachusetts}

Ashwal, L. D., Leo, G. W., Robinson, Peter, Zartman, R. E., and Hall, D. J., 1979, The Belchertown Quartz Monzodiorite pluton, west-central Massachusetts: A syntectonic Acadian intrusion: American Journal of Science, v. 279, no. 8, p. 936-969.

Lithology changed from Dry Hill Granite Gneiss to: Dry Hill Gneiss; Dry Hill Granite Gneiss remains good usage elsewhere in Massachusetts. Age changed from middle Paleozoic to: late Precambrion.

\section{Dry Hollow Formation (name abandoned) Miocene \\ Utah}

Steven, T. A., Cunningham, C. G., Naeser, C. W., and Mehnert, H. H., 1979, Revised stratigraphy and radiometric ages of volcanic rocks and mineral deposits in the Marysvale area, west-central Utah: U.S. Geological Survey Bulletin 1469, 40 p.

Dry Hollow Formation abandoned; its rocks now partly included in Bullion Canyon Volcanics and partly in unnamed lava flows.

\section{Dundee Formation (geographic extension) Middle Devonian Ohio}

Roedder, Edwin, 1979, Fluid inclusion evidence on the environments of sedimentary diagenesis, a review: Society of Economic Paleontologists and Mineralogists Special Publication 26, p. 89-107.

Geographically extended from Michigan into: Ohio.

Duplin Marl or Formation (name abandoned) lower and upper Pliocene North Carolina, South Carolina, Georgia, and Florida

Blackwelder, B. W., and Ward, L. W., 1979, Stratigraphic revision of the Pliocene deposits of North and South Carolina: South Carolina Division of Geology Geologic Notes, v. 23, no. 1, p. 33-49. 
Duplin Marl or Formation abandoned and replaced by: Yorktown Formation in eastern North and eastern South Carolinas, by Raysor Formation (now reinstated) in southern South Carolina and southedstern Georgia, and by Jackson Bluff(?) Formation in Florida.

Dutch Harbor Méfriber (here named)

(of Unalaska Formation)

lower(?) Miocene

southwestern Alaska, Unalaska Island

Lankford, S. M., and Hill, J. M., 1979, Stratigraphy and depositional environment of the Dutch Harbor Member of the Unalaska Formation, Unalaska Island, Alaska: U.S. Geological Survey Bulletin, 1457-B, 14 p.

Dutch Harbor Member adopted and assigned to Unalaska Formation as its only named member. Conformably overlies and underlies unnamed lower and upper volcanic sequences of Unalaska.

\section{Eagle Mountain Shale Member (here named) (of Carrara Formation) \\ Lower Cambrian \\ southeastern California and southern Nevada}

Palmer, A. R., and Halley, R. B., 1979, Physical stratigraphy and trilobite biostratigraphy of the Carrara Formation (Lower and Middle Cambrian), southern Great Basin: U.S. Geological Survey Professional Paper 1047, 131 p.

Eagle Mountain Shale Member adopted as lowermost of nine named members of Carrara Formation. Overlies Emigrant Pass Member (new name) of Zabriskie Quartzite; conformably underlies Thimble Limestone Member (new name) of Carrara.

\section{Echo Shale Member (here named)}

(of Carrara Formation)

Lower Cambrian

southeastern California and southern Nevada

Palmer, A. R., and Halley, R. B., 1979, Physical stratigraphy and trilobite biostratigraphy of the Carrara Formation (Lower and Middle Cambrian), southern Great Basin: U.S. Geological Survey Professional Paper 1047, 131 p.

Echo Shale Member adopted as one of nine members of Carrara Formation. Overlies Thimble Limestone Member (new name) of Carrara; underlies Gold Ace Limestone Member (new name) of Carrara. 


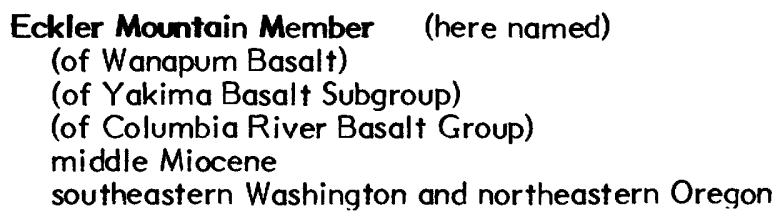

Swanson, D. A., Wright, T. L., Hooper, P. R., and Bentley, R. D., 1979, Revisions in stratigraphic nomenclature of the Columbia River Basalt Group: U.S. Geological Survey Bulletin 1457-G, 59 p.

Eckler Mountain Member adopted and assigned as lowermost of four members to Wanapum Basalt (new name) of Yakima Basalt Subgroup (now raised in rank) of Columbia River Basalt Group (now redefined). Overlies Grande Ronde Basalt (newly adopted) of Yakima; underlies Frenchman Springs Member (now redefined) of Wanapum.

\section{Edisto Formation (reinstated) \\ lower Miocene \\ southern South Carolina}

Ward, L. W., Blackwelder, B. W., Gohn, G. S., and Poore, R. Z., 1979, Stratigraphic revision of Eocene, Oligocene, and lower Miocene formations of South Carolina: South Carolina Division of Geology Geologic Notes, v. 23, no. 1, p. 2-32.

Edisto Marl reinstated as Edisto Formation as used by Malde (1959). Unconformably overlies Cooper Formation; unconformably underlies Raysor Formation (now reinstated); correlates with Belgrade Formation in southeastern North Carolina and with Tampa Limestone in Florida and Georgia.

\section{Elephant Mountain Member (redefined) \\ (of Saddle Mountain Basalt) \\ (of Yakima Basalt Subgroup) \\ (of Columbia River Basalt Group) \\ upper Miocene \\ southern Washington and northern Oregon}

Swanson, D. A., Wright, T. L., Hooper, P. R., and Bentley, R. D., 1979, Revisions in stratigraphic nomenclature of the Columbia River Basalt Group: U.S. Geological Survey Bulletin 1457-G, 59 p.

Elephant Mountain Basalt Member renamed: Elephant Mountain Member, redefined to include Ward Gap Basalt Member of Schmincke (1967), and reassigned to Saddle Mountains Basalt (now redefined) of Yakima Basalt Subgroup (now raised in rank) of Columbia River Basalt Group (now redefined). Unconformably overlies Weissenfels Ridge Member (new name) and conformably underlies Buford Member (newly adopted), both of Saddle Mountains. Age changed from Miocene and Pliocene to: late Miocene. 
Ellensburg Formation (subdivided and age changed)

middle and upper Miocene

Washington and Oregon

Swanson, D. A., Wright, T. L., Hooper, P. R., and Bentley, R. D., 1979, Revisions in stratigraphic nomenclature of the Columbia River Basalt Group: U.S. Geological Survey Bulletin 1457-G, 59 p.

Divided into (ascending): Vantage and Squaw Creek Members (both now renamed and reassigned from Yakima Basalt) and Beverly Member. Age changed from late Miocene and early Pliocene to: middle and late Miocene.

\author{
Emigrant Pass Member (here named) \\ (of Zabriskie Quartzite) \\ Lower Cambrian \\ southern Nevada and southeastern California
}

Palmer, A. R., and Halley, R. B., 1979, Physical stratigraphy and trilobite biostratigraphy of the Carrara Formation (Lower and Middle Cambrian), southern Great Basin: U.S. Geological Survey Professional Paper 1047, 131 p.

Emigrant Pass Member adopted as uppermost unit of Zabriskie Quartzite; underlies Eagle Mountain Shale Member (new name) of Carrara Formation.

\title{
Encinal Member (here named) \\ (of Topanga Canyon Formation) \\ (of Topanga Group) \\ middle Miocene \\ southern California
}

Yerkes, R. F., and Campbell, R. H., 1979, Stratigraphic nomenclature of the central Santa Monica Mountains, Los Angeles County, California: U.S. Geological Survey Bulletin 1457-E, 31 p.

Encinal Member adopted as member of Topanga Canyon Formation (new name) of Topanga Group in area west of Malibu Canyon. Conformably over lies Vaqueros Formation; unconformably underlies Conejo Volcanics.

\section{Escondido Canyon Shale Member (here named) \\ (of Calabasas Formation) \\ (of Topanga Group) \\ middle Miocene \\ southern California}

Yerkes, R. F., and Campbell, R. H., 1979, Stratigraphic nomenclature of the central Santa Monica Mountains, Los Angeles County, California: U.S. Geological Survey Bulletin 1457-E, 31 p. 
Escondido Canyon Shale Member adopted as one of six members of Calabasas Formation (new name) of Topanga Group. Overlies Ramera Canyon Tongue (new name) of Conejo Volcanics; underlies Latigo Canyon Breccia Member (new name) of Calabasas.

\title{
Eshamy Granite （age changed) \\ Oligocene \\ south-central Alaska
}

Tysdal, R. G., and Case, J. E., 1979, Geologic map of the Seward and Blyling Sound Quadrangles, Alaska: U.S. Geological Survey Miscellaneous Investigations Series Map 1-1150, 12 p. text.

Age changed from Mesozoic(?) to: Oligocene.

\author{
Esquatzel Member (here named) \\ (of Saddle Mountains Basalt) \\ (of Yakima Basalt Subgroup) \\ (of Columbia River Basalt Group) \\ middle Miocene \\ southeastern Washington
}

Swanson, D. A., Wright, T. L., Hooper, P. R., and Bentley, R. D., 1979, Revisions in stratigraphic nomenclature of the Columbia River Basalt Group: U.S. Geological Survey Bullet in 1457-G, 59 p.

Esquatzel Member adopted and assigned as one of ten members to: Saddle Mountains Basalt (now redefined) of Yakima Basalt Subgroup (now raised in rank) of Columbia River Basalt Group (now redefined). Unconformably overlies Priest Rapids Member (now redefined) of Wanapum Basalt (new name) unconformably underlies Pomona Member of Saddle Mountains (both now redefined).

\section{Esther Granite (age changed) \\ Oligocene \\ south-central Alaska}

Tysdal, R. G., and Case, J. E., 1979, Geologic map of the Seward and Blyling Sound Quadrangles, Alaska: U.S. Geological Survey Miscellaneous Investigations Series Map I-1150, 12 p. text.

Age changed from Paleozoic(?) to: Oligocene.

\section{Etchegoin Formation (age changed)}

upper Miocene and lower Pliocene

central California 
Sarna-Wojcicki, A. M., Bowman, H. W., and Russell, P. C., 1979, Chemical correlation of some late Cenozoic tuffs of northern and central California by neutron activation analysis of glass and comparison with X-ray fluorescence analysis: U.S. Geological Survey Professional Paper 1147, 15 p.

Age changed from late Miocene to: late Miocene and early Pliocene based on Berggren's 1972 Cenozoic time scale.

\section{Fairview Formation (tongue assigned to) \\ Upper Ordovician \\ southwestern Ohio}

Pojeta, John, Jr., 1979, The Ordovician paleontology of Kentucky and nearby states-introduction: U.S. Geological Survey Professional Paper 1066-A, 48 p.

North Bend Tongue of Ford (1967) adopted and assigned to Fairview Formation in southwestern Ohio. North Bend intertongues with Kope Formation and wedges out in northerly and northwesterly direction. Fairview usage in northcentral Kentucky remains unchanged.

Fernwood Member (here named)

(of Topanga Canyon Formation)

(of Topanga Group)

middle Miocene

southern California

Yerkes, R. F., and Campbell, R. H., 1979, Stratigraphic nomenclature of the central Santa Monica Mountains, Los Angeles County, California: U.S. Geological Survey Bulletin 1457-E, 31 p.

Fernwood Member adopted as middle of three new members of Topanga Canyon Formation (new name) of Topanga Group in area east of Malibu Canyon. Conformably over lies Saddle Peak Member and underlies Cold Creek Member (both new names) of Topanga Canyon.

Fish Brook Gneiss (age changed)

Orodovician or Proterozoic Z

northeastern Massachusetts

Goldsmith, Richard, Stratigraphic names in the New London area, southeastern Connecticut: a revision: this report.

Age changed from Silurian(?) or older to: Ordovician or Proterozoic Z.

Fitch Formation (geographic extension)

Middle Silurian

southwestern New Hampshire and west-central Massachusetts 
Ashwal, L. D., Leo, G. W., Robinson, Peter, Zartman, R. E., and Hall, D. J., 1979, The Belchertown Quartz Monzodiorite pluton, west-central Massachusetts: A syntectonic Acadian intrusion: American Journal of Science, v. 279, no. 8, p. 936-969.

Geographically extended from southwestern New Hampshire into: westcentral Massachusetts. Fitch remains in good usage in eastern Connecticut assigned to Bolton Group.

Fitchville Formation (age changed)

Upper Devonian and Lower Mississippian

central Utah

Morris, H. T., and Lovering, T. S., 1979, General geology and mines of the East Tintic mining district, Utah and Juab Counties, Utah: U.S. Geological Survey Professional Paper 1024, 203 p.

Age changed from Early Mississippian to: Late Devonian and Early Mississippian.

Floyds Knob Bed (geographic extension and reassignment)

(of New Providence Shale Member)

(of Fort Payne Formation)

Lower Mississippian (Osagean)

south-central Kentucky

Kepferle, R. C., Pryor, W. A., Maynard, J. B., and Harrell, James, Jabez Sandstone Member-a new member of the Fort Payne Formation (Mississippian), south-central Kentucky: this report.

Geographically extended from north-central Kentucky into: south-central Kentucky; reassigned from base of Muldraugh Member of Borden Formation to: top of New Providence Shale Member of Fort Payne Formation. Usage of Floyds Knob Formation or Bed remains unchanged elsewhere in Kentucky and in southern Indiana.

\section{Fort Payne Formation (member assigned to) \\ Lower Mississippian \\ south-central Kentucky}

Kepferle, R. C., Pryor, W. A., Maynard, J. B., and Harrell, James, Jabez Sandstone Member--a new member of the Fort Payne Formation (Mississippian), south-central Kentucky: this report.

In south-central Kentucky only, Jabez Sandstone Member (new name) adopted and assigned to upper part of Fort Payne Formation. Jabez overlies unnamed lower part of Fort Payne, intertongues with Cane Valley Limestone Member of Fort Payne, and underlies Salem and Warsaw Formations, undivided. In south-central Kentucky southwest of Borden delta front, Floyds Knob Bed 
reassigned from base of Muldraugh Member of Borden Formation to: top of New Providence Shale Member of Fort Payne. Usage of Fort Payne Formation or Chert remains unchanged in Alabama, Georgia, Tennessee, and Virginia.

\section{Fox Hills Formation (member assigned to)} Upper Cretaceous north-central South Dakota and south-central North Dakota

Howells, Lewis, 1979, Geohydrology of the Cheyenne River Indian Reservation, South Dakota: U.S. Geological Survey Hydrologic Investigations Atlas HA-585, 3 sheets.

Iron Lightning Member of Waage (1968) adopted and assigned to Fox Hills Formation as its uppermost of three members, overlying Timber Lake and Trail City Members of Fox Hills. Fox Hills gradationally over lies Pierre Shale and gradationally underlies Hell Creek Formation. Fox Hills Sandstone or Formation remains good usage elsewhere in North and South Dakotas and in Montana (as Fox Hills Sandstone of Montana Group), Wyoming, Colorado, and Nebraska.

Frederick Limestone (subdivided)

Upper Cambrian (Dresbachian to Trempealeauan)

Frederick Valley, western Maryland

Reinhardt, Juergen, 1977, Cambrian off-shelf sedimentation, central Appalachians: Society of Economic Paleontologists and Mineralogists Special Publication 25, p. 83-112.

In western Maryland only, divided into (ascending): Rocky Springs Station Member (Dresbachian), Adamstown Member (Franconian), and Lime Kiln Member (Trempealeauan). Frederick Limestone usage remains unchanged in Pennsylvania and Virginia.

Frenchman Springs Member (redefined)

(of Wanapum Basalt)

(of Yakima Basalt Subgroup)

(of Columbia River Basalt Group)

middle Miocene

southern Washington and northern Oregon

Swanson, D. A., Wright, T. L., Hooper, P. R., and Bentley, R. D., 1979, Revisions in stratigraphic nomenclature of the Columbia River Basalt Group: U.S. Geological Survey Bulletin 1457-G, 59 p.

Reassigned as one of four members to Wanapum Basalt (new name) of Yakima Basalt Subgroup (now raised in rank) of Columbia River Basalt Group (now redefined). Overlies Eckler Mountain member (new name) and underlies Roza Member (now redefined), both of Wanapum. Its Squaw Creek Diatomite Bed 
raised in rank to: Squaw Creek member and reassigned to Ellensburg Formation. Age of Frenchman Springs changed from late Miocene to: middle Miocene.

Gallagher Peak Sandstone Member (here named)

(of Snaky Canyon Formation)

Upper Pennsylvanian (Missourian)

east-central Idaho

Skipp, Betty, Hoggan, R. D., Schleicher, D. L., and Douglass, R. C., 1979, Upper Paleozoic carbonate bank in east-central Idaho--Snaky Canyon, Bluebird Mountain, and Arco Hills Formations and their paleotectonic significance: U.S. Geological Survey Bulletin 1486, 78 p.

Gallagher Peak Sandstone Member adopted and assigned to Snaky Canyon Formation (new name) as middle of three named members. Gradationally overlies Bloom Member (new name) of Snaky Canyon; gradationally underlies Juniper Gulch Member (new name) of Snaky Canyon.

\section{Garden Valley Formation (age refined) \\ Lower Permian (Roadian, upper Artinskian) \\ central Nevada}

Wardlaw, B. R., and Collinson, J. W., 1979, Youngest Permian conodont faunas from the Great Basin and Rocky Mountain regions, in Sandberg, C. A., and Clark, D. L., editors, Conodont biostratigraphy of the Great Basin and Rocky Mountains: Brigham Young University Geology Studies, v. 26, pt. 3, p. $|5|$ 163.

Age refined from Permian to: Early Permian (Roadian, late Artinskian).

Germer Tuffaceous Member (age changed)

(of Challis Volcanics)

Eocene

eastern Idaho

Staatz, M. H., 1979, Geology and mineral resources of the Lemhi Pass thorium district, Idaho and Montana: U.S. Geological Survey Professional Paper 1049A, 90 p.

Age changed from late Oligocene or early Miocene to: Eocene.

\section{Glen Canyon Group (redefined) \\ Lower Jurassic (Hettangian and Sinemurian) \\ southern Utah and northern Arizona}

Peterson, Fred, and Pipiringos, G. N., 1979, Stratigraphic relations of the Navajo Sandstone to Middle Jurassic formations in parts of southern Utah and northern Arizona: U.S. Geological Survey Professional Paper 1035-B, 43 p. 
Redefined and stratigraphically restricted to exclude rocks of Navajo Sandstone formerly thought to intertonque with Carmel Formation of San Rafael Group (now known to be separated from Navajo by widespread unconformity). Glen Canyon (Navajo) rocks now included in basal part of San Rafael: in southwestern Utah, Temple Cap Sandstone (now raised in rank from member of Navajo and reassigned to San Rafael) and its Sinawava and White Throne Members (both new names); in south-central Utah and northcentral Arizona, Page Sandstone (new name assigned to San Rafael) and its Harris Wash Tongue (new name) and Thousand Pockets Tongue (formerly assigned to Navajo). Glen Canyon usage remains unchanged in Colorado and New Mexico.

\section{Gold Ace Limestone Member (here named)}

(of Carrara Formation)

Lower Cambrian

southern Nevada and southeastern California

Palmer, A. R., and Halley, R. B., 1979, Physical stratigraphy and trilobite biostratigraphy of the Carrara Formation (Lower and Middle Cambrian), southern Great Basin: U.S. Geological Survey Professional Paper 1047, 131 p.

Gold Ace Limestone Member adopted as one of nine members of Carrara Formation. Somewhat gradationally overlies Echo Shale Member (new name) of Carrara; underlies with sharp contact Pyramid Shale Member (new name) of Carrara.

\section{Grand Avenue Member (name adopted)}

(of Kope Formation)

Upper Ordovician

southwestern Ohio and north-central Kentucky

Pojeta, John, Jr., 1979, The Ordovician paleontology of Kentucky and nearby states--introduction: U.S. Geological Survey Professional Paper 1066-A, 48 p.

Grand Avenue Member of Ford (1967) adopted as lower of two named units in Kope Formation (upper unit is Wesselman Tongue). Overlies lower part of Kope Formation; under lies North Bend Tongue of Fairview Formation.

\section{Grande Ronde Basalt (name adopted)}

(of Yakima Basalt Subgroup)

(of Columbia River Basalt Group)

lower and middle Miocene

central and eastern Washington, northern Oregon, and northwestern Idaho

Swanson, D. A., Wright, T. L., Hooper, P. R., and Bentley, R. D., 1979, Revisions in stratigraphic nomenclature of the Columbia River Basalt Group: U.S. Geological Survey Bulletin 1457-G, 59 p.

Grande Ronde Basalt of Taubeneck (1970) adopted as lowermost of three formations of Yakima Basalt Subgroup (now raised in rank) of Columbia River 
Basalt Group (now redefined). Conformably overlies Imnaha Basalt (newly adopted); of Columbia River; disconformably underlies Weissenfels Ridge Member (new name) of Saddle Mountains Basalt (now redefined).

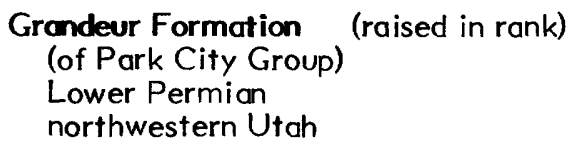

Wardlaw, B. R., Collinson, J. W., and Maughan, E. K., 1979, Stratigraphy of Park City Group equivalents (Permian) in southern Idaho, northeastern Nevada, and northwestern Utah, Chapter C in Wardlaw, B. R., editor, Studies of the Permian Phosphoria Formation and related rocks, Great Basin-Rocky Mountain region: U.S. Geological Survey Professional Paper II63-C, p. 9-16.

In Cedar and Terrace Mountains, Tooele and Box Elder Counties, northwestern Utah, Grandeur Tongue or Member of Park City Formation raised in rank to Grandeur Formation (=Kaibab Limestone in Leach Mountains, Elko County, northeastern Nevada) and assigned to Park City Group as its basal formation. Grandeur Tongue or Member of Park City remains in good usage elsewhere in Utah and in Idaho, Montana, and Wyoming.

Gray Hills Rhyolite Member (name adopted)

(of Mount Belknap Volcanics)

Miocene

west-central Utah

Cunningham, C. G., and Steven, T. A., 1979, Mount Belknap and Red Hills calderas and associated rocks, Marysvale volcanic field, west-central Utah: U.S. Geological Survey Bulletin 1468, 34 p.

Gray Hills Rhyolite of Molloy and Kerr (1962) adopted as Gray Hills Rhyolite Member and assigned to Mount Belknap Volcanics as uppermost of seven members or units near Red Hills caldera. Overlies Red Hills Tuff Member (new name) and unnamed upper red tuff member and partially underlies unnamed upper gray tuff member (all of Mount Belknap).

\section{Greenleaf Mountain Formation (age changed) \\ Proterozoic Z \\ northeastern Massachusetts}

Goldsmith, Richard, Stratigraphic names in the New London area, southeastern Connecticut: a revision: this report.

Age changed from pre-Silurian (late Precambrian? to Ordovician?) to: Proterozoic Z. 
Half Dome Granodiorite (lithology changed and age refined)

(of Tuolumne Intrusive Series)

lower Upper Cretaceous

central Califomia

Bateman, P. C., and Chappell, B. W., 1979, Crystallization, fractionation, and solidification of the Tuolumne Intrusive Series, Yosemite National Park, California: Geological Society of America Bulletin, Part I, v. 90, no. 5, p. 465-482.

Lithology changed from Half Dome Quartz Monzonite to: Half Dome Granodiorite. Age refined from Late Cretaceous to: early Late Cretaceous.

Hardwick Quartz Diorite (lithology and age changed)

Lower Devonian

west-central Massachusetts and southwestern New Hampshire

Ashwal, L. D., Leo, G. W., Robinson, Peter, Zartman, R. E., and Hall, D. J., 1979, The Belchertown Quartz Monzodiorite pluton, west-central Massachusetts: A syntectonic Acadian intrusion: American Journal of Science, v. 279, no. 8, p. 936-969.

Lithology changed from Hardwick Granite to: Hardwick Quartz Diorite; Hardwick Granite remains good usage elsewhere in Massachusetts and New Hampshire. Age changed from Late Devonian(?) to: Early Devonian.

\title{
Harleyville Member (here named) \\ (of Cooper Formation) \\ upper Eocene to lowermost Oligocene(?) \\ southern South Carolina
}

Ward, L. W., Blackwelder, B. W., Gohn, G. S., and Poore, R. Z., 1979, Stratigraphic revision of Eocene, Oligocene, and lower Miocene formations of South Carolina: South Carolina Division of Geology Geologic Notes, v. 23, no. I, p. 2-32.

Cooper Formation divided into (ascending): Harleyville (new name), Parkers Ferry (new name), and Ashley Members. Harleyville overlies Cross Member (new name) of Santee Limestone and underlies Parkers Ferry or Ashley Member of Cooper.

\author{
Harris Wash Tongue (here named) \\ (of Page Sandstone) \\ (of San Rafael Group) \\ Middle Jurassic (Bajocian) \\ southern Utah
}

Peterson, Fred, and Pipiringos, G. N., 1979, Stratigraphic relations of the Navajo Sandstone to Middle Jurassic formations in parts of southern Utah and northern Arizona: U.S. Geological Survey Professional Paper 1035-B, 43 p. 
Harr is Wash Tongue adopted and assigned as lower of two tongues to Page Sandstone (new name) of San Rafael Group (now stratigraphically extended). Overlies Navajo Sandstone of Glen Canyon Group; underlies Judd Hollow Tongue of Carmel Formation of San Rafael.

Hawthorn Formation (member assigned to)

lower and middle Miocene (Burdigalian to Serravallian) southeastern South Carolina and eastern Georgia

Abbott, W. H., and Andrews, G. W., 1979, Middle Miocene marine diatoms from the Hawthorn Formation of the Ridgeland Trough, South Carolina and Georgia: Micropaleontology, v. 25, no. 3, p. 225-27l.

Coosawhatchie Clay of Heron and others (1965) adopted as Coosawhatchie Clay Member of upper part of Hawthorn Formation following Johnson (1965). Coosawhatchie correlates with upper half of Choptank Formation of Maryland. Usage of Hawthorn Formation of Alum Bluff Group remains unchanged in Florida.

\section{Hells Half Acre Tuff Member (age changed) (of Galiuro Volcanics) \\ Miocene or upper Oligocene southeastern Arizona}

Krieger, M. H., 1979, Ash-flow tuffs of the Galiuro Volcanics in the northern Galiuro Mountains, Pinal County, Arizona: U.S. Geological Survey Professional Paper 1104, 32 p.

Age changed from Miocene to: Miocene or late Oligocene.

\section{Holy Joe Member (age changed) \\ (of Galiuro Volcanics) \\ upper Oligocene \\ southeastern Arizona}

Krieger, M. H., 1979, Ash-flow tuffs of the Galiuro Volcanics in the northern Galiuro Mountains, Pinal County, Arizona: U.S. Geological Survey Professional Paper 1104, 32 p.

Age changed from Miocene to: late Oligocene.

Hope Valley Alaskite Gneiss (age changed)

(of Sterling Plutonic Group)

Proterozoic Z

western Rhode Island and eastern Connecticut

Goldsmith, Richard, Stratigraphic names in the New London area, southeastern Connecticut: a revision: this report.

Age changed from Mississippian(?) or older to: Proterozoic Z. 
Hunting Hill Greenstone (its affiliation name and its age changed) (of Blackstone Group)

Proterozoic Z

Rhode Island

Goldsmith, Richard, Stratigraphic names in the New London area, southeastern Connecticut: a revision: this report.

Its affiliation name changed from Blackstone Series to: Blackstone Group. Age of Blackstone and its four formations (Mussey Brook, Quinnville, Sneech Pond, Hunting Hill) changed from Precambrian(?) to: Proterozoic Z.

\author{
Ice Harbor Member (name adopted) \\ (of Saddle Mountains Basalt) \\ (of Yakima Basalt Subgroup) \\ (of Columbia River Basalt Group) \\ upper Miocene \\ southeastern Washington
}

Swanson, D. A., Wright, T. L., Hooper, P. R., and Bentley, R. D., 1979, Revisions in stratigraphic nomenclature of the Columbia River Basalt Group: U.S. Geological Survey Bulletin 1457-G, 59 p.

"Flows at Ice Harbor Dam" of Wright and others (1973) formalized and adopted as Ice Harbor Member, one of ten members of Saddle Mountains Basalt (now redefined) of Yakima Basalt Subgroup (now raised in rank) of Columbia River Basalt Group (now redefined). Overlies Elephant Mountain Member (now redefined) of Saddle Mountains.

\title{
Imnaha Basalt (name adopted) \\ (of Columbia River Basalt Group) \\ lower Miocene \\ northeastern Oregon, southeastern Washington, and northwestern Idaho
}

Swanson, D. A., Wright, T. L., Hooper, P. R., and Bentley, R. D., 1979, Revisions in stratigraphic nomenclature of the Columbia River Basalt Group: U.S. Geological Survey Bulletin 1457-G, 59 p.

Imnaha Formation of Vallier (1967) adopted as Imnaha Basalt as used by Taubeneck (1970) and Hooper (1974) and assigned to Columbia River Basalt Group (now redefined) as its lowermost formation. Unconformably overlies pre-Tertiary rocks; conformably underlies Grande Ronde Basalt (newly adopted) of Yakima Basalt Subgroup (now raised in rank) of Columbia River.

Iron Lightning Member (name adopted)

(of Fox Hills Formation)

Upper Cretaceous (Maestrichtian)

north-central South Dakota and south-central North Dakota 
Howells, Lewis, 1979, Geohydrology of the Cheyenne River Indian Reservation, South Dakota: U.S. Geological Survey Hydrologic Investigations Atlas HA-585, 3 sheets.

Iron Lightning Member of Waage (1968) adopted and assigned to Fox Hills Formation as its uppermost of three members in type locality of Fox Hill, Ziebach and Dewey Counties, north-central South Dakota; Iron Lightning geographically extended northward into: Corson County, South Dakota, and Emmons County, south-central North Dakota. Over lies Timber Lake and Trail City Members of Fox Hills; gradationally underlies Hell Creek Formation; correlated with Colgate Member of Fox Hills in east-central Montana and northwestern North Dakota.

\section{Ironshire Formation (here named)}

Pleistocene (upper Sangamon)

Maryland, Virginia, and Delaware, central Delmarva

Peninsula

Owens, J. P., and Denny, C. S., 1979, Upper Cenozoic deposits of the central Delmarva Peninsula, Delaware and Maryland, Chapter $A$ in Surface and shallow subsurface geologic studies in the emerged Coastal Plain of the Middle Atlantic states: U.S. Geological Survey Professional Paper 1067-A, 28 p.

Ironshire Formation adopted. Unconformably overlies Beaverdam Sand or Omar Formation.

\section{Ivanhoe Member (reassigned) \\ (of Shady Dolomite) \\ Lower Cambrian \\ southwestern Virginia}

Reinhardt, Juergen, 1977, Cambrian off-shelf sedimentation, central Appalachians: Society of Economic Paleontologists and Mineralogists Special Publication 25, p. 83-112.

Reassigned from Rome Formation as Ivanhoe Limestone Member to: Shady Dolomite as Ivanhoe Member.

\section{Jabez Sandstone Member (here named) \\ (of Fort Payne Formation) \\ Lower Mississippion \\ south-central Kentucky}

Kepferle, R. C., Pryor, W. A., Maynard, J. B., and Harrell, James, Jabez Sandstone Member-a new member of the Fort Payne Formation (Mississippian), south-central Kentucky: this report.

Jabez Sandstone Member adopted and assigned to upper part of Fort Payne Formation. Overlies unnamed lower part of Fort Payne; intertongues with Cane Valley Limestone Member of Fort Payne; underlies Salem and Warsaw Formations, undivided. 
Joe Lott Tuff Member (reduced in rank and assigned)

(of Mount Belknap Volcanics)

Miocene

west-central Utah

Cunningham, C. G., and Steven, T. A., 1979, Mount Belknap and Red Hills calderas and associated rocks, Marysvale volcanic field, west-central Utah: U.S. Geological Survey Bulletin 1468, 34 p.

Reduced in rank from Joe Lott Tuff to: Joe Lott Tuff Member and assigned to Mount Belknap Volcanics as one of seven members or units near Red Hills caldera. Unconformably overlies Three Creeks Tuff Member of Bullion Canyon Volcanics; underlies Red Hills Tuff Member of Mount Belknap and Sevier River Formation.

Johnson Gronite Porphyry (age refined)

(of Tuolumne Intrusive Series)

lower Upper Cretaceous

central California

Bateman, P. C., and Chappell, B. W., 1979, Crystallization, fractionation, and solidification of the Tuolumne Intrusive Series, Yosemite National Park, California: Geological Society of America Bulletin, Part I, v. 90, no. 5, p. 465482.

Age refined from Cretaceous to: early Late Cretaceous.

Joshua Rock Member (assigned to group and name and age changed)

(of New London Gneiss)

(of Waterford Group)

Proterozoic Z

eastern Connecticut

Goldsmith, Richard, Stratigraphic names in the New London area, southeastern Connecticut: a revision: this report.

Name changed from Joshua Rock Gneiss Member to: Joshua Rock Member; remains assigned to lower part of New London Gneiss, underlying its unnamed granodiorite gneiss member. New London now assigned as middle of three formations to Waterford Group (new name), overlying Mamacoke Formation of Waterford and underlying Rope Ferry Gneiss (new name) of Waterford. Age of Joshua Rock changed from Ordovician(?) or older to: Proterozoic Z.

\footnotetext{
Juniper Gulch Member (here named)

(of Snaky Canyon Formation)

Upper Pennsylvanian and Lower Permian

(Missourian to Wolfcampian)

east-central Idaho
}

Skipp, Betty, Hoggan, R. D., Schleicher, D. L., and Douglass, R. C., 1979, Upper Paleozoic carbonate bank in east-central Idaho--Snaky Canyon, Bluebird Mountain, 
and Arco Hills Formations and their paleotectonic significance: U.S. Geological Survey Bulletin 1486, 78 p.

Juniper Gulch Member adopted and assigned to Snaky Canyon Formation (new name) as its uppermost of three named members. Gradationally overlies Gallagher Peak Member (new name) of Snaky Canyon; conformably and abruptly underlies Phosphoria Formation.

Kaibab Limestone (assignment to group)

(of Park City Group)

Lower Permian

northeastern Nevada

Wardlaw, B. R., Collinson, J. W., and Maughan, E. K., 1979, Stratigraphy of Park City Group equivalents (Permian) in southern Idaho, northeastern Nevada, and northwestern Utah, Chapter C in Wardlaw, B. R., editor, Studies of the Permian Phosphoria Formation and related rocks, Great Basin-Rocky Mountain region: U.S. Geological Survey Professional Paper 1163-C, p. 9-16.

In northeastern Nevada, Kaibab assigned to: Park City Group. Kaibab usage remains unchanged (not assigned to group) elsewhere in Nevada and in Arizona, California, and Utah.

\section{Kendal Green Formation (age changed)}

Proterozoic Z

eastern Massachusetts

Goldsmith, Richard, Stratigraphic names in the New London area, southeastern Connecticut: a revision: this report.

Age changed from Precambrian Z(?) to: Proterozoic Z.

Kendrick Shale Member (name adopted)

(of Breathitt Formation)

Middle Pennsylvanian (Morrowan)

eastern Kentucky

Rice, C. L., Kendrick Shale Member of the Breathitt Formation in eastern Kentucky: this report.

Kendrick Shale of Jillson (1919) adopted, redefined as Kendrick Shale Member, and assigned to middle part of Breathitt Formation. Overlies Williamson (Amburgy) coal bed or coal zone; underlies Whitesburg coal zone.

\section{Kent Island Formation (here named)}

Pleistocene (upper Sangamon or middle Wisconsin)

Maryland and Delaware, central Delmarva Peninsula

Owens, J. P., and Denny, C. S., 1979, Upper Cenozoic deposits of the central Delmarva Peninsula, Delaware and Maryland, Chapter A in Surface and shallow 
subsurface geologic studies in the emerged Coastal Plain of the Middle Atlantic states: U.S. Geological Survey Professional Paper 1067-A, 28 p.

Kent Island Formation adopted. Incised into or lies against Chesapeake Group, Pensauken Formation, and Beaverdam Sand; probably equivalent to Ironshire Formation (new name) and Omar Formation; probably correlated with Sinepuxent Formation (new name).

\section{Kewanee Group (geographic extension)} Middle Pennsylvanian

Illino is and Indiana

Solem, Alan, and Yochelson, E. L., 1979, North American Paleozoic land snails, with a summary of other Paleozoic nonmarine snails: U.S. Geological Survey Professional Paper 1072, $42 \mathrm{p}$.

Geographically extended from Illino is into: Indiana.

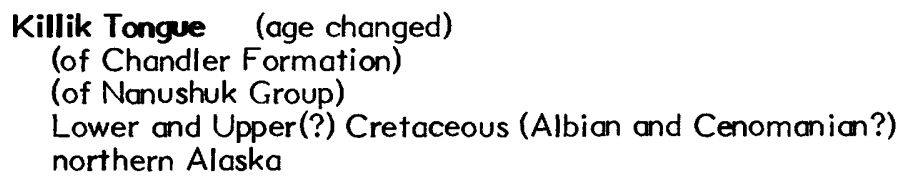

May, F. E., 1979, Dinoflagellate and Acritarch assemblages from the Nanushuk Group (Albian-Cenomanian) and the Torok Formation (Albian), Umiat Test Well II, National Petroleum Reserve in Alaska, northern Alaska, in Ahlbrandt, T. S., editor, Preliminary geologic, petrologic, and paleontologic results of the study of Nanushuk Group rocks, North Slope, Alaska: U.S. Geological Survey Circular 794, p. 113-127.

Age changed from Early Cretaceous to: Early and Late(?) Cretaceous (Albian and Cenomanian?).

\section{Kinzers Formation (age changed)}

Lower and Middle Cambrian

south-central Pennsylvania

Reinhardt, Juergen, 1977, Cambrian off-shelf sedimentation, central Appalachians: Society of Economic Paleontologists and Mineralogists Special Publication 25, p. 83-112.

Age changed from Early Cambrian to: Early and Middle Cambrian. Kinzers Formation remains good usage in Maryland and Virginia.

\section{Kittitas Drift (name adopted)}

Pleistocene

central Washington 
Waitt, R. B., Jr., 1979, Late Cenozoic deposits, landforms, stratigraphy, and tectonisn, in Kittitas Valley, Washington: U.S. Geological Survey Professional Paper $1127,18 \mathrm{p}$.

Kittitas Drift of Porter (1975, 1976) adopted. Includes Porter's Swauk Prairie and overlying Indian John Members redesignated as informal names Swauk Prairie and Indian John phases (reinterpreted as local time-stratigraphic units, not rockstratigraphic units).

Kope Formation (geographic extension and subdivision)

Upper Ordovician

southwestern Ohio, north-central Kentucky, and southeastern Indiana

Pojeta, John, Jr., 1979, The Ordovician paleontology of Kentucky and nearby states-introduction: U.S. Geologcial Survey Professional Paper 1066-A, 48 p.

Geographically extended into southeastern Indiana from southwestern Ohio and north-central Kentucky. Divided into (ascending): Grand Avenue Member and Wesselman Tongue. Overlies Point Pleasant Tongue of Clays Ferry Formation; under lies Fairview or Dillsboro Formation.

Laguna Springs Volcanic Group (raised in rank and subdivided) middle Oligocene central Utah

Morris, H. T., and Lovering, T. S., 1979, General geology and mines of the East Tintic mining district, Utah and Juab Counties, Utah: U.S. Geological Survey Professional Paper 1024, 203 p.

Raised in rank to Laguna Springs Volcanic Group. Divided into (ascending): North Standard, Pinyon Queen, and Tintic Delmar Latites (all three new names). Unconformably overlies Big Canyon Latite of Tintic Mountain Volcanic Group (both new names); underlies Pinyon Creek Conglomerate (new name).

\section{Lake Bonneville Group (formation assigned to)}

Pleistocene and Holocene

north-central Uath

Van Horn, Richard, 1979, The Holocene Ridgeland Formation and associated Decker Soil (new names) near Great Salt Lake, Utah: U.S. Geological Survey Bulletin 1457-C, $11 \mathrm{p}$.

Ridgeland Formation adopted and assigned to Lake Bonneville Group. Ridgeland overlies Midvale Soil and underlies Decker Soil (new name).

\section{Lakedale Drift (name adopted)}

Pleistocene

central Washington 
Waitt, R. B., Jr., 1979, Late Cenozoic deposits, landforms, stratigraphy, and tectonism in Kittitas Valley, Washington: U.S. Geological Survey Professional Paper $1127,18 \mathrm{p}$.

Lakedale Drift of Porter (1975, 1976) adopted and identified with Fraser Glaciation of Puget Lowland and with late Wisconsin Glaciation of mid-continent.

\section{Lamar River Formation (geographic restriction)}

upper lower to lower middle Eocene

northwestern Wyoming

Pierce, W. G., 1979, Clastic dikes of Heart Mountain fault breccia, northwestern Wyoming, and their significance: U.S. Geological Survey Professional Paper 1133, $35 \mathrm{p}$.

Geographically restricted from Heart Mountain fault area of northwestern Wyoming; replaced by Wapiti Formation (now geographically extended). Lamar River Formation of Washburn Group of Absaroka Volcanic Supergroup remains good usage elsewhere in northwestern Wyoming and in south-central Montana.

\section{Latigo Canyon Breccia Member (here named) (of Calabasas Formation) \\ (of Topanga Group) \\ middle Miocene \\ southern California}

Yerkes, R. F., and Campbell, R. H., 1979, Stratigraphic nomenclature of the central Santa Monica Mountains, Los Angeles County, California: U.S. Geological Survey Bulletin 1457-E, $31 \mathrm{p}$.

Latigo Canyon Breccia Member adopted as one of six new members of Calabasas Formation (new name) of Topanga Group. Overlies Escondido Canyon Shale Member (new name) of Calabasas; underlies Solstice Canyon Tongue (new name) of Conejo Volcanics; intertongues with unnamed epiclastic volcanic breccia.

\section{Latite Ridge Latite (here named)}

(of Tintic Mountain Volcanic Group)

middle Oligocene

central Utah

Morris, H. T., and Lovering, T. S., 1979, General geology and mines of the East Tintic mining district, Utah and Juab Counties, Utah: U.S. Geological Survey Professional Paper 1024, 203 p.

Latite Ridge Latite adopted and assigned to Tintic Mountain Volcanic Group (new name) as middle of three members. Divided into (ascending): unnamed airfall tuff member and unnamed welded tuff member. Unconformably overlies Copperopolis Latite and unconformably underlies Big Canyon Latite, both new names of Tintic Mountain. 


\section{Lee Gneiss (lithology and age changed) Proterozoic $Y$ western Massachusetts}

Ratcliffe, N. M., and Hatch, N. L., Jr., 1979, A traverse across the Taconide zone in the area of the Berkshire massif, western Massachusetts, in Skehan, J. S., and Osberg, P. H., editors, The Caledonides in the U.S.A.; Geological excursions in the northeast Appalachians--Contributions to the International Geological Correlation Program (IGCP), Project 27--Caledonide Orogen: Weston, Mass., Boston University, Weston Observatory, p. 175-224.

Lithology changed from Lee Quartz Diorite to: Lee Gneiss. Age changed from Precambrian to: Proterozoic $Z$.

\section{Lime Kiln Member (name adopted)}

(of Frederick Limestone)

Upper Cambrian (Trempealeauan)

Frederick Valley, western Maryland

Reinhardt, Juergen, 1977, Cambrian off-shelf sedimentation, central Appalachians: Society of Economic Paleontologists and Mineralogists Special Publication 25, p. 83-112.

Lime Kiln Member of Reinhardt (1974) adopted as upper of three members of Frederick Limestone. Overlies Adamstown Member of Frederick; underlies Grove Limestone (or Formation).

\section{Llajas Formation (name adopted) middle Eocene southern California}

Yerkes, R. F., and Campbell, R. H., 1979, Stratigraphic nomenclature of the central Santa Monica Mountains, Los Angeles County, California: U.S. Geological Survey Bulletin 1457-E, $31 \mathrm{p}$.

Llajas Formation of Schenck (1931) adopted and questionably recognized in report area. Overlies Coal Canyon Formation (new name); underlies Sespe Formation.

\section{Lodgepole Limestone (its member geographically extended)}

Lower Mississippian (Kinderhookian and Osagean)

northeastern Utah

Sandberg, C. A., and Gutschick, R. C., 1979, Guide to conodont biostratigraphy of Upper Devonian and Mississippian rocks along the Wasatch front and Cordilleran hingeline, Utah, in Sandberg, C. A., and Clark, D. L., editors, Conodont biostratigraphy of the Great Basin and Rocky Mountains: Brigham Young University Geology Studies, v. 26, pt. 3, p. 107-133.

Cottonwood Canyon, basal member of Lodgepole Limestone, geographically extended from so ift irn Montana into: northeastern Utah; age is Early 
Mississippian (Kinderhookian) only. Cottonwood Canyon Member of Madison Limestone of late Late Devonian and Early Mississippian age remains good usage in northern and west-central Wyoming. Lodgepole, without Cottonwood Canyon as its basal member, of Madison Group remains good usage in Wyoming, Idaho, North Dakota, and elsewhere in Montana and Utah.

\title{
Lookout Mountain Ranch Drift (here named) \\ Pleistocene \\ central Washington
}

Waitt, R. B., Jr., 1979, Late Cenozoic deposits, landforms, stratigraphy, and tectonism in Kittitas Valley, Washington: U.S. Geological Survey Professional Paper 1127, 18 p.

Lookout Mountain Ranch Drift adopted. Unconformably overlies Grande Ronde Basalt.

\section{Loveland Loess (geographic extension) \\ Pleistocene \\ northeastern Colorado}

Tweto, Ogden, compiler, 1979, Geologic map of Colorado: U.S. Geological Survey Geologic Map of Colorado.

Geographically extended from lowa, Nebraska, Missouri, Indiana, Illinois, South Dakota, Kansas, and Kentucky into: northeastern Colorado as Loveland Loess. Usage of Loveland Loess or Formation or Silt remains unchanged elsewhere.

\author{
Lower Monumental Member (here named) \\ (of Saddle Mountains Basalt) \\ (of Yakima Basalt Subgroup) \\ (of Columbia River Basalt Group) \\ middle Miocene \\ southeastern Washington
}

Swanson, D. A., Wright, T. L., Hooper, P. R., and Bentley, R. D., 1979, Revisions in stratigraphic nomenclature of the Columbia River Basalt Group: U.S. Geological Survey Bulletin 1457-G, 59 p.

Lower Monumental Member adopted and assigned as uppermost of ten members to: Saddle Mountains Basalt (now redefined) of Yakima Basalt Subgroup (now raised in rank) of Columbia River Basalt Group (now redefined). Believed to be younger than Ice Harbor Member (newly adopted) of Saddle Mountains and believed to be youngest known basalt of Columbia River Basalt Group.

\footnotetext{
McRae Formation (name adopted)

Upper Cretaceous and lower Tertiary

central New Mexico
} 
Segerstrom, Kenneth, Stotelmeyer, R. B., and Williams, F. E., 1979, Mineral resources of the White Mountain Wilderness and adjacent areas, Lincoln County, New Mexico: U.S. Geological Survey Bulletin 1453, 135 p.

McRae Formation of Kelley and Silver (1952) adopted. Unconformably overlies Mesaverde Formation; underlies Oligocene volcanic rocks.

\section{Madisonville Limestone Member (age changed) \\ (of Sturgis Formation) \\ Middle Pennsylvanian (Des Moinesian) \\ western Kentucky}

Douglass, R. C., 1979, The distribution of fusulinids and their correlation between the Illinois Basin and the Appalachian Basin, in Palmer, J. E., and Dutcher, R. R., editors, Depositional and structural history of the Pennsylvanian System of the Illino is Basin, Part 2: Invited papers, Field trip 9/Ninth International Congress of Carboniferous Stratigraphy and Geology, Urbana, Illinois, 1979: Illinois State Geological Survey Guidebook Series 15a, p. 15-20.

Age changed from Late Pennsylvanian to: Middle Pennsylvanian (Des Moinesian).

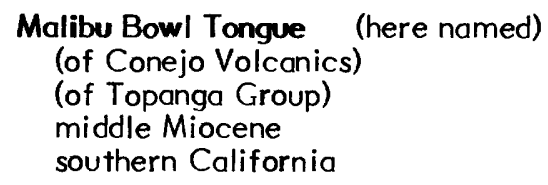

Yerkes, R. F., and Campbell, R. H., 1979, Stratigraphic nomenclature of the central Santa Monica Mountains, Los Angeles County, California: U.S. Geological Survey Bulletin 1457-E, $31 \mathrm{p}$.

Malibu Bowl Tongue adopted as uppermost of three new tongues of Conejo Volcanics of Topanga Group. Geographically restricted to upper plate of Malibu Bowl fault. Overlies Solstice Canyon Tongue (new name) of Conejo; underlies and intertongues with Newell Sandstone Member of Calabasas Formation (hoth new names).

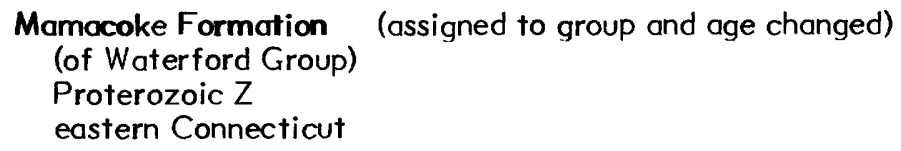

Goldsmith, Richard, Stratigraphic names in the New London area, southeastern Connecticut: a revision: this report.

Assigned as lowermost of three formations to Waterford Group (new name). Overlies Plainfield Formation; underlies New London Gneiss with its Joshua Rock Member and overlying unnamed granodiorite gneiss member (all newly assigned to Waterford Group). Age changed from pre-Silurian to: Proterozoic Z. 
Marca Shale Member (name adopted)

(of Moreno Shale)

Upper Cretaceous

central California

Murata, K. J., Dibblee, T. W., Jr., and Drinkwater, J. L., 1979, Thermal effects of Iarge bodies of intrusive serpentinite on overlying Monterey Shale, southern Diablo Range, Cholame area, California: U.S. Geological Survey Professional Paper 1082, 8 p.

Marca Shale Member of Payne (1941, 1951) adopted and assigned to lower part of Moreno Shale.

Mariquita Chert (name adopted)

Upper Jurassic and Lower Cretaceous

(upper Tithonian through Hauterivian)

southwestern Puerto Rico

Krushensky, R. D., and Monroe, W. H., 1978, Geologic map of the Yuaco and Punta Verraco Quadrangles, Puerto Rico: U.S. Geological Survey Miscellaneous Investigations Series Map 1-1147.

Mariquita Chert of Mattson (1973) adopted. Overlies unnamed pre-Tithonian serpentinite and amphibolite; underlies unnamed Cretaceous sequence at Media Quijada, unnamed Cretaceous augite andesite lava flows, and unnamed Oligocene mudstone and conglomerate member of Juana Diaz Formation.

\section{Marlboro Formation (age changed)}

Proterozoic Z, Cambrian, or Ordovician

eastern Massachusetts and eastern Rhode Island

Goldsmith, Richard, Stratigraphic names in the New London area, southeastern Connecticut: a revision: this report.

Age changed from Precambrian Z(?) to early Paleozoic to: Proterozoic Z, Cambrian, or Ordovician.

\section{Martinez Formation (geographic restriction) \\ Paleocene \\ west-central California}

Yerkes, R. F., and Campbell, R. H., 1979, Stratigraphic nomenclature of the central Santa Monica Mountains, Los Angeles County, California: U.S. Geological Survey Bulletin 1457-E, 31 p.

Geographically restricted from coastal southern California; its rocks replaced by Coal Canyon Formation (new name) in Santa Monica Mountains. 


\author{
Mayflower Hill Formation (name abandoned) \\ Lower Silurian \\ south-central Maine
}

Osberg, P. H., 1979, Geologic relationships in south-central Maine, in Skehan, J. S., and Osberg, P. H., editors, The Caledonides in the U.S.A.; Geological excursions in the northeast Appalachians--Contributions to the International Geological Correlation Program (IGCP), Project 27--Caledonide Orogen: Weston, Mass., Boston University, Weston Observatory, p. 37-62.

Mayflower Hill Formation abandoned; its rocks replaced by lower part of Sangerville Formation (newly adopted).

\author{
Mesa Peak Breccia Member (here named) \\ (of Calabasas Formation) \\ (of Topanga Group) \\ middle Miocene \\ southern California
}

Yerkes, R. F., and Campbell, R. H., 1979, Stratigraphic nomenclature of the central Santa Monica Mountains, Los Angeles County, California: U.S. Geological Survey Bulletin 1457-E, $31 \mathrm{p}$.

Mesa Peak Breccia Member adopted as uppermost of six new members of Calabasas Formation (new name) of Topanga Group. Geographically restricted to upper plate of Malibu Bowl Fault. Conformably overlies Newell Sandstone Member (new name) of Calabasas; underlies(?) Modelo Formation.

Miamitown Shale (name adopted)

Upper Ordovician

southwestern Ohio

Pojeta, John, Jr., 1979, The Ordovician paleontology of Kentucky and nearby states-introduction: U.S. Geologcial Survey Professional Paper 1066-A, 48 p.

Miamitown Shale of Ford (1967) adopted. Overlies Fairview Formation; underlies "Bellevue Limestone" as used by Ford (1967) (= Bellevue Tongue of Grant Lake Limestone of north-central Kentucky).

\title{
Middlesex Fells Volcanic Complex (age changed) \\ Proterozoic Z \\ nor theastern Massachusetts
}

Goldsmith, Richard, Stratigraphic names in the New London area, southeastern Connecticut: a revision: this report.

Age changed from pre-Silurian (Precambrian?) to: Proterozoic Z: 
Monson Gneiss (geographic restriction)

Lower to Middle Ordovician

New London area of southeastern Connecticut

Goldsmith, Richard, Stratigraphic names in the New London area, southeastern Connecticut: a revision: this report.

Geographically restricted from New London area of southeastern Connecticut; replaced by rocks of Rope Ferry Gneiss of Waterford Group (both new names). Monson remains good usage elsewhere in Connecticut and in Massachusetts.

\title{
Moreno Shale (member assigned to) \\ Upper Cretaceous and Paleocene \\ central California
}

Murata, K. J., Dibblee, T. W., Jr., and Drinkwater, J. L., 1979, Thermal effects of large bodies of intrusive serpentinite on overlying Monterey Shale, southern Diablo Range, Cholame area, California: U.S. Geological Survey Professional Paper 1082, 8 p.

Marca Shale Member (Upper Cretaceous) of Payne (1941, 1951) adopted and assigned to lower part of Moreno Shale.

\section{Moultrie Member (here named) \\ (of Santee Limestone) \\ middle Eocene (middle Claibornian) \\ southern South Carolina}

Ward, L. W., Blackwelder, B. W., Gohn, G. S., and Poore, R. Z., 1979, Stratigraphic revision of Eocene, Oligocene, and lower Miocene formations of South Carolina: South Carolina Division of Geology Geologic Notes, v. 23, no. 1, p. 2-32.

Santee Limestone divided into (ascending): Moultrie and Cross Members (both new names). Moultrie correlates with Lisbon Formation in Alabama, New Hanover Member of Castle Hayne Formation in southeastern North Carolina, and upper part of Nanjemoy Formation in eastern Virginia. Moultrie overlies Black Mingo Formation and underlies Cross Member of Santee.

\author{
Mount Baldy Rhyolite Member (here named) \\ (of Mount Belknap Volcanics) \\ Miocene \\ west-central Utah
}

Cunningham, C. G., and Steven, T. A., 1979, Mount Belknap and Red Hills calderas and associated rocks, Marysvale volcanic field, west-central Utah: U.S. Geological Survey Bulletin 1468, $34 \mathrm{p}$.

Mount Baldy Rhyolite Member adopted as uppermost of five members of Mount Belknap Volcanics in Mount Belknap caldera. Overlies unnamed middle tuff and sedimentary breccia members of Mount Belknap. 


\author{
Mount Belknop Volcanics (lithology changed and subdivided) \\ Miocene \\ west-central Utah
}

Cunningham, C. G., and Steven, T. A., 1979, Mount Belknap and Red Hills calderas and associated rocks, Marysvale volcanic field, west-central Utah: U.S. Geological Survey Bulletin 1468, 34 p.

Lithology name changed from Mount Belknap Rhyolite to: Mount Belknap Volcanics. Divided into (ascending): in west in Mount Belknap caldera--unnamed lower tuff member, Blue Lake Rhyolite Member (new name), unnamed middle tuff member, unnamed sedimentary breccia member, and Mount Baldy Rhyolite Member (new name); in east near Red Hills caldera--unnamed tuff and flow units, Joe Lott Tuff Member (now reduced in rank), Red Hills Tuff Member (new name), unnamed crystal-rich tuff member, unnamed upper red tuff member, Gray Hills Rhyolite Member, and unnamed upper gray tuff member.

\title{
Murdock Mountain Formation (here named) \\ (of Park City Group) \\ Lower Permian (Roadian to lowermost Wordian) \\ northeastern Nevada and northwestern Utah
}

Wardlaw, B. R., Collinson, J. W., and Maughan, E. K., 1979, The Murdock Mountain Formation: a new unit of the Permian Park City Group, Chapter B in Wardlaw, B. R., editor, Studies of the Permian Phosphoria Formation and related rocks, Great Basin-Rocky Mountain region: U.S. Geological Survey Professional Paper 1163-B, p. 5-8.

Murdock Mountain Formation adopted as lower of two formations of Park City Group. Conformably overlies Meade Peak Tongue of Phosphoria Formation conformably underlies Gerster Limestone of Park City; lateral equivalent of Plympton Formation of Park City in west-central Utah and east-central Nevada and of Rex Chert Member of Phosphoria Formation in southwestern Idaho.

\footnotetext{
Mussey Brook Schist (its affiliation name and its age changed) (of Blackstone Group)

Proterozoic Z

Rhode Island
}

Goldsmith, Richard, Stratigraphic names in the New London area, southeastern Connecticut: a revision: this report.

Its affiliation name changed from Blackstone Series to: Blackstone Group. Age of Blackstone and its four formations (Mussey Brook, Quinnville, Sneech Pond, Hunting Hill) changed from Precambrian(?) to: Proterozoic Z.

Narrow Cape Formation (minor geographic extension and age changed) upper Oligocene or lowermost Miocene south-central Alaska 
Fisher, M. A., 1979, Structure and tectonic setting of the continental shelf southwest of Kodiak Island, Alaska: American Association of Petroleum Geologists Bulletin, v. 63, no. 3, p. 301-310.

Geographically extended from Kodiak Island into: Sitkinak Island. Age changed from middle Miocene to: late Oligocene or earliest Miocene.

\section{Narrow Cape Formation (age changed) \\ upper Oligocene(?) and lower and middle Miocene \\ south-central Alaska}

Nilsen, T. H., and Moore, G. W., 1979, Reconnaissance study of Upper Cretaceous to Miocene stratigraphic units and sedimentary facies, Kodiak and adjacent islands, Alaska: U.S. Geological Survey Professional Paper 1093, 34 p.

Age changed from late Oligocene or earliest Miocene to: late Oligocene(?) and early and middle Miocene.

\section{Nashoba Formation (age changed) \\ Ordovician or Proterozoic Z \\ northeastern Massachusetts}

Goldsmith, Richard, Stratigraphic names in the New London area, southeastern Connecticut: a revision: this report.

Age of Nashoba and its Boxford Member (and by inference its other nine members: Bellows Hill, Billerica, Spencer Brook, Tophet Swamp, Nashoba Brook, Nagog Pond, Fort Pond, Long Pond, and Beaver Brook) changed from pre-Silurian to: Ordovician or Proterozoic Z.

\section{Navajo Sandstone (stratigraphic restriction) (of Glen Canyon Group) \\ Lower Jurassic (Sinemurian) \\ northern Arizona and southern Utah}

Peterson, Fred, and Pipiringos, G. N., 1979, Stratigraphic relations of the Navajo Sandstone to Middle Jurassic formations in parts of southern Utah and northern Arizona: U.S. Geological Survey Professional Paper 1035-B, 43 p.

Stratigraphically restricted to exclude rocks formerly thought to intertongue with Carmel Formation (now known to be separated from Navajo by widespread unconformity). Its rocks now included in basal part of San Rafael Group: in southwestern Utah, Temple Cap Sandstone (now raised in rank from member of Navajo and reassigned to San Rafael) and its Sinawava and White Throne Members (both new names); in south-central Utah and north-central Arizona, Page Sandstone (new name assigned to San Rafael) and its Harris Wash Tongue (new name) and Thousand Pockets Tongue (formerly assigned to Navajo). Navajo usage remains unchanged in Colorado and New Mexico. 
Nellie Juan Granite (age changed)

Oligocene

south-central Alaska

Tysdal, R. G., and Case, J. E., 1979, Geologic map of the Seward and Blyling Sound Quadrangles, Alaska: U.S. Geological Survey Miscellaneous Investigations Series Map I-1150, 12 p. text.

Age changed from Mesozoic(?) to: Oligocene.

Newell Sandstone Member (here named)

(of Calabasas Formation)

(of Topanga Group)

middle Miocene

southern California

Yerkes, R. F., and Campbell, R. H., 1979, Stratigraphic nomenclature of the central Santa Monica Mountains, Los Angeles County, California: U.S. Geological Survey Bulletin 1457-E, 3I p.

Newell Sandstone Member adopted as one of six new members of Calabasas Formation (new name) of Topanga Group. Geographically restricted to upper plate of Malibu Bowl fault. Conformably overlies Dry Canyon Sandstone Member and conformably underlies Mesa Peak Breccia Member (both new names) of Calabasas; intertongues westward into Malibu Bowl Tongue (new name) of Conejo Volcanics.

New London Gneiss (assigned to group and age changed) (of Waterford Group)

Proterozoic Z eastern Connecticut

Goldsmith, Richard, Stratigraphic names in the New London area, southeastern Connecticut: a revision: this report.

Assigned as middle of three formations to Waterford Group (new name). Overlies Mamacoke Formation of Waterford; underlies Rope Ferry Gneiss (new name) of Waterford; includes Joshua Rock Member (name changed from Joshua Rock Gneiss Member) and overlying unnamed granodiorite gneiss member. Age changed from Ordovician(?) or older to: Proterozoic Z.

New Providence Shale Member (bed reassigned to)

(of Fort Payne Formation)

Lower Mississippian (Osagean)

south-central Kentucky

Kepferle, R. C., Pryor, W. A., Maynard, J. B., and Harrell, James, Jabez Sandstone Member-a new member of the Fort Payne Formation (Mississippian), south-central Kentucky: this report. 
In south-central Kentucky southwest of Borden delta front, Floyds Knob Bed reassigned from base of Muldraugh Member of Borden Formation to: top of New Providence Shale Member of Fort Payne Formation. Usage of New Providence Shale or Shale Member remains unchanged elsewhere in Kentucky and in Indiana and Tennessee.

Nineveh Limestone Member (geographic extension and age refined)

(of Greene Formation)

(of Dunkard Group)

Lower Permian

Pennsylvania and Ohio

Solem, Alan, and Yochelson, E. L., 1979, North American Paleozoic land snails, with a summary of other Paleozoic nonmarine snails: U.S. Geological Survey Professional Paper 1072, $42 \mathrm{p}$.

Geographically extended from Pennsylvania into: Ohio. Age refined from Permian to: Early Permian.

Nopah Formation (age changed)

Upper Cambrian and Lower Ordovician

California and Nevada

Harris, A. G., Bergström, S. M., Ethington, R. L., and Ross, R. J., Jr., 1979, Aspects of Middle and Upper Ordovician conodont biostratigraphy of carbonate facies in Nevada and southeast California and comparison with some Appalachian successions, in Sandberg, C. A., and Clark, D. L., editors, Conodont biostratigraphy of the Great Basin and Rocky Mountains: Brigham Young University Geology Studies, v. 26, pt. 3, p. 7-43.

Age changed from Late Cambrian to: Late Cambrian and Early Ordovician.

North Bend Tongue (name adopted)

(of Fairview Formation)

Upper Ordovicion

southwestern Ohio

Pojeta, John, Jr., 1979, The Ordovician paleontology of Kentucky and nearby states-introduction: U.S. Geological Survey Professional Paper 1066-A, 48 p.

North Bend Tongue of Ford (1967) adopted as unit in Fairview Formation. intertongues with Kope Formation and wedges out in northerly and northwesterly direction.

North Standard Latite (here named)

(of Laguna Springs Volcanic Group)

middle Oligocene

central Utah 
Morris, H. T., and Lovering, T. S., 1979, General geology and mines of the East Tintic mining district, Utah and Juab Counties, Utah: U.S. Geological Survey Professional Paper 1024, 203 p.

North Standard Latite adopted and assigned to Laguna Springs Volcanic Group (now raised in rank) as lowermost of three formations. Unconformably overlies Big Canyon Latite of Tintic Mountain Volcanic Group (both new names); underlies Pinyon Queen Latite (new name) of Laguna Springs.

Omar Formation . (name adopted)

Pleistocene (lower Sangamon)

Delaware, Maryland, and Virginia, central Delmarva Peninsula

Owens, J. P., and Denny, C. S., 1979, Upper Cenozoic deposits of the central Delmarva Peninsula, Delaware and Maryland, Chapter A in Surface and shallow subsurface geologic studies in the emerged Coastal Plain of the Middle Atlantic states: U.S. Geological Survey Professional Paper 1067-A, 28 p.

Omar Formation of Jordan (1962) and Jordan and others (1967) adopted. Overlies Beaverdam Sand and Chesapeake Group; underlies Ironshire Formation, Sinepuxent Formation, and Parsonsburg Sand; is onlapped by Kent Island Formation (new name).

Oonatut Granite Complex (here named)

Upper Cretaceous

northwestern Alaska

Hudson, Travis, 1979, Igneous and metamorphic rocks of the Serpentine Hot Springs area, Seward Peninsula, Alaska: U.S. Geological Survey Professional Paper 1079, $27 \mathrm{p}$.

Oonatut Granite Complex adopted; intrudes unnamed Precambrian(?) and Paleozoic metamorphic rocks.

\section{Owens Valley Formation (age refined)}

Lower and Upper Permian (Aktastinian, Leonardian, Roadian, Wordian; Artinskian to lower Guadalupian) southeastern California

Wardlaw, B. R., and Collinson, J. W., 1979, Youngest Permian conodont faunas from the Great Basin and Rocky Mountain regions, in Sandberg, C. A., and Clark, D. L., editors, Conodont biostratigraphy of the Great Basin and Rocky Mountains: Brigham Young University Geology Studies, v. 26, pt. 3, p. 151-163.

Age refined from Permian to: Early and Late Permian (Aktastinian, Leonardian, Roadian, Wordian; Artinskian to early Guadalupian). 


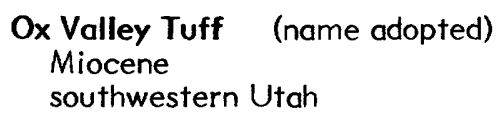

Rowley, P. D., Steven, T. A., Anderson, J. J., and Cunningham, G. C., 1979, Cenozoic stratigraphic and structural framework of southwestern Utah: U.S. Geological Survey Professional Paper 1149, 22 p.

Ox Valley Tuff of Cook (1960a) adopted. Overlies Cove Mountain Formation; underlies unnamed rhyolite.

\section{Pablo Formation (age changed) \\ Mississippian \\ central Nevada}

Jones, D. L., 1979, Age of type Pablo Formation in central Nevada, in Geological Survey research 1979: U.S. Geological Survey Professional Paper II50, p. 82.

Age changed from Early Triassic to: Mississippian.

\section{Page Sandstone (here named) \\ (of San Rafael Group) \\ Middle Jurassic (Bajocian and Bathonian) \\ north-central Arizona and south-central Utah}

Peterson, Fred, and Pipiringos, G. N., 1979, Stratigraphic relations of the Navajo Sandstone to Middle Jurassic formations in parts of southern Utah and northern Arizona: U.S. Geological Survey Professional Paper I035-B, 43 p.

Page Sandstone adopted and assigned to basal part of San Rafael Group (now stratigraphically extended), replacing upper part of Navajo Sandstone of Glen Canyon Group (now stratigraphically restricted). Divided into (ascending): Harris Wash Tongue (new name) and Thousand Pockets Tongue (formerly assigned to Navajo). Overlies Navajo Sandstone of Glen Canyon; underlies Carmel Formation of San Rafael.

\section{Page Ranch Formation (name adopted) Miocene southwestern Utah}

Rowley, P. D., Steven, T. A., Anderson, J. J., and Cunningham, G. C., 1979, Cenozoic stratigraphic and structural framework of southwestern Utah: U.S. Geological Survey Professional Paper 1149, 22 p.

Page Ranch Formation of Cook (1957) adopted. Overlies Rencher Formation; underlies Racer Canyon Tuff. 


\author{
Pahrump Hills Shale Member (here named) \\ (of Carrara Formation) \\ Middle Cambrian \\ southern Nevada and southeastern California
}

Palmer, A. R., and Halley, R. B., 1979, Physical stratigraphy and trilobite biostratigraphy of the Carrara Formation (Lower and Middle Cambrian), southern Great Basin: U.S. Geological Survey Professional Paper 1047, 131 p.

Pahrump Hills Shale Member adopted as one of nine members of Carrara Formation. Overlies Red Pass Limestone Member (new name) of Carrara; underlies Jangle Limestone Member of Carrara.

\title{
Parguera Limestone (name adopted) \\ Upper Cretaceous (Campanian through upper Maestrichtian) southwestern Puerto Rico
}

Krushensky, R. D., and Monroe, W. H., 1978, Geologic map of the Yuaco and Punta Verraco Quadrangles, Puerto Rico: U.S. Geological Survey Miscellaneous Investigations Series Map I-1/47.

Parguera Limestone of Mattson (1960) adopted. Underlies unnamed Cretaceous sequence at Media Quijada and unnamed Oligocene mudstone and conglomerate member of Juana Diaz Formation.

\section{Pork City Group (new formation assigned to) Lower and Upper Permian northeastern Nevada and northwestern Utah}

Wardlaw, B. R., Collinson, J. W., and Maughan, E. K., 1979, The Murdock Mountain Formation: a new unit of the Permian Park City Group, Chapter B in Wardlaw, B. R., editor, Studies of the Permian Phosphoria Formation and related rocks, Great Basin-Rocky Mountain region: U.S. Geological Survey Professional Paper II63-B, p. 5-8.

In northeastern Nevada and northwestern Utah, divided into (ascending): Murdock Mountain Formation (new name) and Gerster Limestone. Former usage of Park City Formation or Group remains unchanged elsewhere in Nevada and Utah and in Colorado, Idaho, Montana, and Wyoming.

Park City Formation or Group (locally subdivided and age changed) Lower Permian only (varies locally) northwestern Utah, northeastern Nevada, and southern Idaho

Wardlaw, B. R., Collinson, J. W., and Maughan, E. K., 1979, Stratigraphy of Park City Group equivalents (Permian) in southern Idaho, northeastern Nevada, and northwestern Utah, Chapter C in Wardlaw, B. R., editor, Studies of the Permian Phosphoria Formation and related rocks, Great Basin-Rocky Mountain region: U.S. Geological Survey Professional Paper II63-C, p. 9-16. 
Divided into (ascending): in Terrace Mountains, northwestern Utah, Grandeur (raised to formation rank), Murdock Mountain (new name), and Gerster Formations of Park City Group; in Cedar Mountains, northwestern Utah, Grandeur, Plympton, and Gerster Formations of Park City Group; in Leach Mountains, northeastern Nevada, Kaibab Limestone and Murdock Mountain and Gerster Formations; and in Cassia Mountains, southern Idaho, Grandeur Tonque of Park City Formation only. Age in report area changed from Early and Late Permian to: Early Permian only. Usage and age of Park City Formation or Group remains unchanged elsewhere in Utah, Nevada, and Idaho and in Colorado, Montana, and Wyoming.

\title{
Parkers Ferry Member (here named) (of Cooper Formation) \\ upper Eocene \\ southern South Carolina
}

Ward, L. W., Blackwelder, B. W., Gohn, G. S., and Poore, R. Z., 1979, Stratigraphic revision of Eocene, Oligocene, and lower Miocene formations of South Carolina: South Carolina Division of Geology Geologic Notes, v. 23, no. 1, p. 2-32.

Cooper Formation divided into (ascending): Harleyville (new name), Parkers Ferry (new name), and Ashley Members. Parkers Ferry overlies Harleyville Member of Cooper and underlies Ashley Member of Cooper.

\section{Parsonsburg Sand (geographic extension) \\ Pleistocene (upper Wisconsinan) \\ southeastern Maryland and southern Delaware}

Denny, C. S., Owens, J. P., Sirkin, L. A. and Rubin, Meyer, 1979, The Parsonsburg Sand in the central Delmarva Peninsula, Maryland and Delaware, Chapter $B$ in Surface and shallow subsurface geologic studies in the emerged coastal plain of the Middle Atlantic states: U.S. Geological Survey Professional Paper 1067-B, 16 p.

Geographically extended from southeastern Maryland in to: southern Delaware.

\author{
Picture Gorge Basalt (redefined) \\ (of Columbia River Basalt Group) \\ lower Miocene \\ north-central Oregon
}

Swanson, D. A., Wright, T. L., Hooper, P. R., and Bentley, R. D., 1979, Revisions in stratigraphic nomenclature of the Columbia River Basalt Group: U.S. Geological Survey Bulletin 1457-G, 59 p.

Geographically restricted to north-central Oregon; geographically restricted from northeastern Oregon and southeastern Washington, where its rocks are reassigned to older Imnaha Basalt (newly adopted). Unconformably overlies John Day Formation or Imnaha Basalt; conformably underlies Mascall Formation or Grande Ronde Basalt (newly adopted). Age changed from middle Miocene to: early Miocene. 
Pinesburg Station Dolomite (geographic extension)

(of Beekmantown Group)

Middle Ordovicion

northern West Virginia

Harris, A. G., Bergström, S. M., Ethington, R. L., and Ross, R. J., Jr., 1979, Aspects of Middle and Upper Ordovician conodont biostratigraphy of carbonate facies in Nevada and southeast California and comparison with some Appalachian successions, in Sandberg, C. A., and Clark, D. L., editors, Conodont biostratigraphy of the Great Basin and Rocky Mountains: Brigham Young University Geology Studies, v. 26, pt. 3, p. 7-43.

Geographically extended from western Maryland and northern Virginia into: northern West Virginia.

\title{
Pinyon Creek Conglomerate (here named)
} lower Miocene central Utah

Morris, H. T., and Lovering, T. S., 1979, General geology and mines of the East Tintic mining district, Utah and Juab Counties, Utah: U.S. Geological Survey Professional Paper 1024, 203 p.

Pinyon Creek Conglomerate adopted. Disconformably overlies Packard Quartz Latite or intervening Laguna Springs Volcanic Group; disconformably underlies Silver Shield Quartz Latite (new name).

\section{Pinyon Peak Limestone (age changed) Upper Devonian central Utah}

Morris, H. T., and Lovering, T. S., 1979, General geology and mines of the East Tintic mining district, Utah and Juab Counties, Utah: U.S. Geological Survey Professional Paper 1024, 203 p.

Age changed from Late Devonian and Ear'y Mississippian to: Late Devonian.

\author{
Pinyon Queen Latite (here named) \\ (of Laguna Springs Volcanic Group) \\ middle Oligocene \\ central Utah
}

Morris, H. T., and Lovering, T. S., 1979, General geology and mines of the East Tintic mining district, Utah and Juab Counties, Utah: U.S. Geological Survey Professional Paper 1024, 203 p.

Pinyon Queen Latite adopted and assigned to Laguna Springs Volcanic Group (now raised in rank) as middle of three formations. Divided into two unnamed members. Overlies Packard Quartz Latite, North Standard Latite (new name) of 
Laguna Springs, or Latite Ridge and Big Canyon Latites of Tintic Mountain Volcanic Group (all three new names); underlies Tintic Delmar Latite (new name) of Laguna Springs.

\author{
Piuma Member (here named) \\ (of Sespe Formation) \\ lower Miocene \\ southern California
}

Yerkes, R. F., and Campbell, R. H., 1979, Stratigraphic nomenclature of the central Santa Monica Mountains, Los Angeles County, California: U.S. Geological Survey Bulletin 1457-E, 31 p.

Piuma Member adopted as uppermost part of Sespe Formation. Interfingers with Vaqueros Formation; under lies Topanga Canyon Formation (new name).

\title{
Plainfield Formation (age changed) \\ Proterozoic Z \\ eastern Connecticut, western Rhode Island, and eastern Massachusetts
}

Goldsmith, Richard, Stratigraphic names in the New London area, southeastern Connecticut: a revision: this report.

Age changed from Precambrian(?) to: Proterozoic Z.

\author{
Point Pleasant Tongue (geographic extension) \\ (of Clays Ferry Formation) \\ Middle and Upper Ordovician \\ southwestern Ohio, north-central Kentucky, and \\ southeastern Indiana
}

Pojeta, John, Jr., 1979, The Ordovician paleontology of Kentucky and nearby states--introduction: U.S. Geological Survey Professional Paper 1066-A, 48 p.

Geographically extended from southwestern Ohio and north-central Kentucky into: southeastern Indiana as Point Pleasant Tongue of Clays Ferry Formation. Point Pleasant Formation or I imestone remains good usage elsewhere in Ohio and Kentucky.

\section{Pomona Member (redefined) \\ (of Saddle Mountains Basalt) \\ (of Yakima Basalt Subgroup) \\ (of Columbia River Basalt Group) \\ middle Miocene \\ south-central Washington and northern Oregon}

Swanson, D. A., Wright, T. L., Hooper, P. R., and Bentley, R. D., 1979, Revisions in stratigraphic nomenclature of the Columbia River Basalt Group: U.S. Geological Survey Bulletin 1457-G, 59 p. 
Pomona Flow renamed: Pomona Member and reassigned as one of ten members: to Saddle Mountains Basalt (now redefined) of Yakima Basalt Subgroup (now raisec in rank) or Columbia River Basalt Group (now redefined). Interbedded witt Ellensburg Formation; overlies Esquatzel Member (new name) and underlies Elephant Mountain Member (now redefined), both of Saddle Mountains. Age changed from Miocene or Pliocene to: middle Miocene.

Ponaganset Gneiss (assigned to group and age changed)

(of Sterling Plutonic Group)

Proterozoic Z

western Rhode Island and eastern Connecticut

Goldsmith, Richard, Stratigraphic names in the New London area, southeasterr Connecticut: a revision: this report.

Assigned to Sterling Plutonic Group as lowermost of five formations. Age changed from Mississippian(?) or older to: Proterozoic Z.

\section{Poplar Mountain Gneiss (age changed)}

upper Precambrian

west-central Massachusetts

Ashwal, L. D., Leo, G. W., Robinson, Peter, Zartman, R. E., and Hall, D. J., 197?? The Belchertown Quartz Monzodiorite pluton, west-central Massachusetts: A syntectonic Acadian intrusion: American Journal of Science, v. 279, no. 8, p. 936 969.

Age changed from middle Paleozoic to: late Precambrian.

Potter Hill Granite Geniss (assigned to group and age changed)

(of Sterling Plutonic Group)

Proterozoic Z

western Rhode Island and eastern Connecticut

Goldsmith, Richard, Stratigraphic names in the New London area, southeasterr Connecticut: a revision: this report.

Assigned to Sterling Plutonic Group as one of five formations; considerec approximately equivalent to Scituate Granite Gneiss (of Sterling). Age channe: from Mississippian(?) or older to: Proterozoic Z.

\section{Preston Gabbro (age changed)}

Silurian

southeastern Connecticut

Goldsmith, Richard, Stratigraphic names in the New London area, southeastiarr Connecticut: a revision: this report.

Age changed from Carboniferous or post-Carboniferous to: Silurian. 


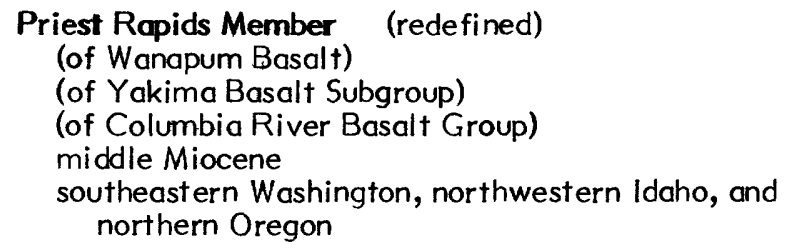

Swanson, D. A., Wright, T. L., Hooper, P. R., and Bentley, R. D., 1979, Revisions in stratigraphic nomenclature of the Columbia River Basalt Group: U.S. Geological Survey Bulletin 1457-G, 59 p.

Geographically extended from southeastern Washington into: northwestern Idaho and northern Oregon. Reassigned as uppermost of four members of Wanapum Basalt (new name) of Yakima Basalt Subgroup (now raised in rank) of Columbia River Basalt Group (now redefined). Overlies Roza Member (now redefined) of Wanapum; underlies Umatilla: Member of Saddle Mountains Basalt (both now rede fined). Its Quincy Diatomite. Bed abandoned; its rocks now included in Squaw Creek Member (now raised i $A_{\text {: }}$ rank and reassigned) of Ellensburg Formation. Age changed from late Miocene to: middle Miocene.

\title{
Providence Limestone Member (age changed) \\ (of Sturgis Formation) \\ Middle Pennsylvanian (Des Moinesian) \\ western Kentucky
}

Douglass, R. C., 1979, The distribution of fusulinids and their correlation between the Illino is Basin and the Appalachian Basin, in Palmer, J. E., and Dutcher, R. R., editors, Depositional and structural history of the Pennsylvanian System of the Illino is Basin, Part 2: Invited papers, Field trip 9/Ninth International Congress of Carboniferous Stratigraphy and Geology, Urbana, Illinois, 1979: Illinois State Geological Survey Guidebook Series 15a, p. 15-20.

Age changed from Late Pennsylvanian to: Middle Pennsylvanian (Des Moinesian).

\section{Putnam Group (age changed)}

Ordovician, Cambrian, or Proterozoic Z eastern Connecticut

Goldsmith, Richard, Stratigraphic names in the New London area, southeastern Connecticut: a revision: this report.

Age changed from Middle(?) Ordovician or older to: Ordovician, Cambrian, or Proterozoic $Z$.

\author{
Putnam Hill Limestone Member (geographic extension and age refined) \\ (of Allegheny Formation) \\ Middle Pennsylvanian (Des Moinesian) \\ east-central Ohio and west-central Pennsylvania
}


Douglass, R. C., 1979, The distribution of fusulinids and their correlation between the Illino is Basin and the Appalachian Basin, in Palmer, J. E., and Dutcher, R. R., editors, Depositional and structural history of the Pennsylvanian System of the Illino is Basin, Part 2: Invited papers, Field trip 9/Ninth International Congress of Carboniferous Stratigraphy and Geology, Urbana, Illinois, 1979: Illinois State Geological Survey Guidebook Series 15a, p. 15-20.

Geographically extended from eastern Ohio into: west-central Pennsylvania. Age refined from Pennsylvanian to: Middle Pennsylvanian (Des Moinesian).

\section{Putney Volcanics (name adopted) \\ Devonian \\ south-central and southeastern Vermont and north-central Massachusetts}

Trask, N. J., The Putney Volcanics in southeastern Vermont and north-central Massachusetts: this report.

Putney Volcanics of Hepburn (1972a, b) adopted and geographically extended from Vermont into: north-central Massachusetts. Bordered on east by Littleton Formation (Lower Devonian) and on west by Gile Mountain Formation (Lower Devonian).

\section{Pyramid Shale Member (here named) \\ (of Carrara Formation) \\ Lower and Middle Cambrian \\ southeastern California and southern Nevada}

Palmer, A. R., and Halley, R. B., 1979, Physical stratigraphy and trilobite biostratigraphy of the Carrara Formation (Lower and Middle Cambrian), southern Great Basin: U.S. Geological Survey Professional Paper 1047, 131 p.

Pyramid Shale Member adopted as one of nine members of Carrara Formation. Overlies with sharp contact Gold Ace Limestone Member (new name) of Carrara; conformably underlies Red Pass Limestone Member (new name) of Carrara.

\section{Quincy Diatomite Bed (name abandoned)}

(of Priest Rapids Member)

(of Yakima Basalt)

(of Columbia River Basalt Group)

upper Miocene

Washington

Swanson, D. A., Wright, T. L., Hooper, P. R., and Bentley, R. D., 1979, Revisions in stratigraphic nomenclature of the Columbia River Basalt Group: U.S. Geological Survey Bulletin 1457-G, 59 p.

Quincy Diatomite Bed abandoned; its rocks now included in Squaw Creek Member (now raised in rank and reassigned) of Ellensburg Formation. 


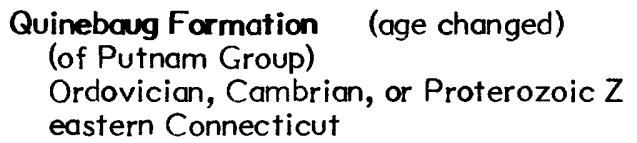

Goldsmith, Richard, Stratigraphic names in the New London area, southeastern Connecticut: a revision: this report.

Age changed from Middle(?) Ordovician or older to: Ordovician, Cambrian, or Proterozoic $Z$.

Quinnville Quartzite (its affiliation name and its age changed) (of Blackstone Group)

Proterozoic Z

Rhode Island

Goldsmith, Richard, Stratigraphic names in the New London area, southeastern Connecticut: a revision: this report.

Its affiliation name changed from Blackstone Series to: Blackstone Group. Age of Blackstone and its four formations (Mussey Brook, Quinnville, Sneech Pond, Hunting Hill) changed from Precambrian(?) to: Proterozoic Z.

\section{Racer Canyon Tuff (name adopted) \\ Miocene \\ southwestern Utah}

Rowley, P. D., Steven, T. A., Anderson, J. J., and Cunningham, G. C., 1979, Cenozoic stratigraphic and structural framework of southwestern Utah: U.S. Geological Survey Professional Paper 1149, 22 p.

Racer Canyon Tuff Member of Cove Mountain Formation of Cook (1960b) raised in rank and adopted as Racer Canyon Tuff as used by Mackin (1960). Over lies Page Ranch Formation; under lies basin fill sediments.

\section{Ramera Canyon Tangue (here named) \\ (of Conejo Volcanics) \\ (of Topanga Group) \\ middle Miocene \\ southern California}

Yerkes, R. F., and Campbell, R. H., 1979, Stratigraphic nomenclature of the central Santa Monica Mountains, Los Angeles County, California: U.S. Geological Survey Bulletin 1457-E, 31 p.

Ramera Canyon Tongue adopted as lowermost of three new tongues of Conejo Volcanics of Topanga Group. Geographically restricted to upper plate of Malibu Bowl fault. Overlies Topanga Canyon Formation (new name) of Topanga; inter fingers with and under lies Calabasas Formation (new name) of Topanga. 


\section{Ranchester Dolomite Member (lithology changed) \\ (of Amsden Formation) \\ Upper Mississippian to Middle Pennsylvanian (varies) \\ central Wyoming}

Thaden, R. E., 1980, Geologic map of the Guffy Peak quadrangle, showing chromolithofacies in the Wind River Formation, Fremont and Hot Springs Counties, Wyoming: U.S. Geological Survey Geologic Quadrangle Map GQ-1527.

In Guffy Peak and De Pass quadrangles of central Wyoming, lithology of Ranchester Limestone Member changed to: Ranchester Dolomite Member. Lithology remains unchanged elsewhere in Wyoming.

Raysor Formation (name reinstated and redefined)

lower Pliocene

southern South Carolina and southeastern Georgia

Blackwelder, B. W., and Ward, L. W., 1979, Stratigraphic revision of the Pliocene deposits of North and South Carolina: South Carolina Division of Geology Geologic Notes, v. 23, no. I, p. 33-49.

Raysor Marl reinstated and redefined as Raysor Formation and extended from southern South Carolina into: southeastern Georgia, replacing Duplin Marl or Formation (now abandoned). Unconformably overlies Cooper Formation; grades into Yorktown Formation to west and north. Age changed from late Miocene to: early Pliocene.

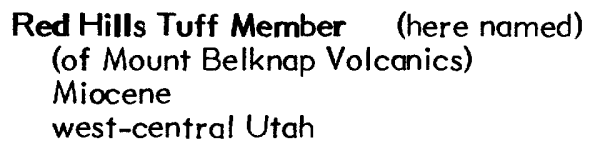

Cunningham, C. G., and Steven, T. A., 1979, Mount Belknap and Red Hills calderas and associated rocks, Marysvale volcanic field, west-central Utah: U.S. Geological Survey Bulletin 1468, 34 p.

Red Hills Tuff Member adopted as one of seven members or units of Mount Belknap Volcanics in and near Red Hills caldera. Overlies Joe Lott Tuff Member (now reduced in rank) and underlies Gray Hills Rhyolite Member (both of Mount Belknap).

Red Pass Limestone Member (here named)

(of Carrara Formation)

Middle Cambrian

southeastern California and southern Nevada

Palmer, A. R., and Halley, R. B., 1979, Physical stratigraphy and trilobite biostratigraphy of the Carrara Formation (Lower and Middle Cambrian), southern Great Basin: U.S. Geological Survey Professional Paper 1047, 131 p. 
Red Pass Limestone Member adopted as one of nine members of Carrara Formation. Conformably overlies Pyramid Shale Member (new name) of Carrara; under lies with sharp contact Pahrump Hills Shale Member (new name) of Carrara.

\author{
Redwater Member (redefined) \\ (of Stump Formation) \\ Upper Jurassic (Oxfordian) \\ central, northeastern, and north-central Utah, \\ southeastern Idaho, southwestern Wyoming, and \\ northwesternmost Colorado
}

Pipiringos, G. N., and Imlay, R. W., 1979, Lithology and subdivisions of the Jurassic Stump Formation in southeastern Idaho and adjoining areas: U.S. Geological Survey Professional Paper 1035-C, 25 .

Geographically extended from central and northeastern Utah into: north-central Utah, southwestern Wyoming, southeastern Idaho, and northwesternmost Colorado, where name changed from Redwater Shale Member to: Redwater Member; reassigned from Sundance Formation to Stump Formation as upper of two named members. Overlies Curt is Member (reduced in rank) of Stump; underlies Ephraim Conglomerate. Redwater Shale Member of Sundance remains good usage elsewhere in Colorado and Wyoming and in western South Dakota.

\title{
Rencher Formation (name adopted)
}

Miocene

southwestern Utah

Rowley, P. D., Steven, T. A., Anderson, J. J., and Cunningham, G. C., 1979, Cenozoic stratigraphic and structural framework of southwestern Utah: U.S. Geological Survey Professional Paper 1149, 22 p.

Rencher Formation of Cook (1957) adopted. Overlies Harmony Hills Tuff; underlies unnamed volcanic rocks or Page Ranch Formation.

\section{Retort Phosphatic Shale Member (age changed)}

(of Phosphoria Formation)

Lower Permian (Wordian, lower Guadalupian)

Montana, Idaho, Utah, and Wyoming

Wardlaw, B. R., 1979, Transgression of the Retort Phosphatic Shale Member of the Phosphoria Formation (Permian) in Idaho, Montana, Utah, and Wyoming, Chapter A in Wardlaw, B. R., editor, Studies of the Permian Phosphoria Formation and related rocks, Great Basin-Rocky Mountain region: U.S. Geological Survey Professional Paper 1163-A, p. 1-4.

Age changed from Late Permian to: Early Permian (Wordian, early Guadalupian). 
Rex Chert Member or Tongue (age changed)

(of Phosphoria Formation)

Lower Permian

northwestern Utah and southern Idaho

Wardlaw, B. R., Collinson, J. W., and Maughan, E. K., 1979, Stratigraphy of Park City Group equivalents (Permian) in southern Idaho, northeastern Nevada, and northwestern Utah, Chapter C in Wardlaw, B. R., editor, Studies of the Permian Phosphoria Formation and related rocks, Great Basin-Rocky Mountain region: U.S. Geological Survey Professional Paper 1163-C, p. 9-16.

Age changed from Late Permian to: Early Permian. Rex Chert Member or Tongue remains in good usage elsewhere in Utah and Idaho and in Montana and Wyoming.

Ridgeland Formation (here named)

(of Lake Bonneville Group)

Holocene

north-central Utah

Van Horn, Richard, 1979, The Holocene Ridgeland Formation and associated Decker Soil (new names) near Great Salt Lake, Utah: U.S. Geological Survey Bulletin 1457-C, $11 \mathrm{p}$.

Ridgeland Formation adopted and assigned to Lake Bonneville Group. Unconformably overlies Midvale Soil; grades into overlying Decker Soil (new name).

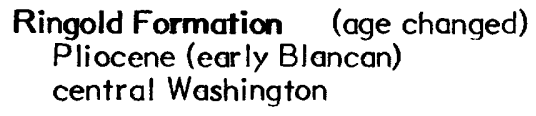

Waitt, R. B., Jr., 1979, Late Cenozoic deposits, landforms, stratigraphy, and tectonism in Kittitas Valley, Washington: U.S. Geological Survey Professional Paper 1127, $18 \mathrm{p}$.

Age changed from Pliocene and Pleistocene to: Pliocene (early Blancan).

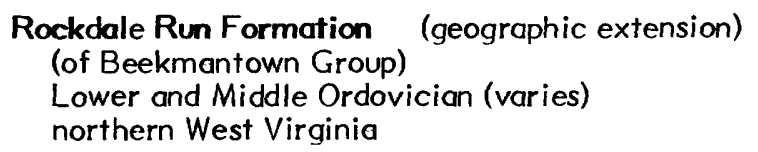

Harris, A. G., Bergström, S. M., Ethington, R. L., and Ross, R. J., Jr., 1979, Aspects of Middle and Upper Ordovician conodont biostratigraphy of carbonate facies in Nevada and southeast California and comparison with some Appalachian successions, in Sandberg, C. A., and Clark, D. L., editors, Conodont biostratigraphy of the Great Basin and Rocky Mountains: Brigham Young University Geology Studies, v. 26, pt. 3, p. 7-43. 
Geographically extended from western Maryland, northern Virginia, and southcentral Pennsylvania into: northern West Virginia.

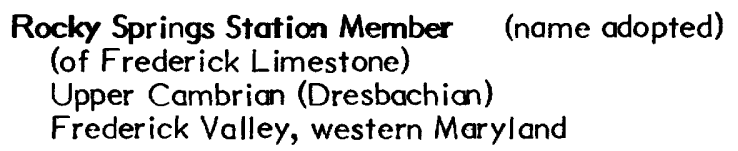

Reinhardt, Juergen, 1977, Cambrian off-shelf sedimentation, central Appalachians: Society of Economics Paleontologists and Mineralogists Special Publication 25, p. 83-112.

Rocky Springs Station Member of Reinhardt (1974) adopted as lower of three memers of Frederick Limestone. Overlies Araby Formation; underlies Adamstown Member of Frederick.

\author{
Rope Ferry Gneiss (here named) \\ (of Waterford Group) \\ Proterozoic Z \\ eastern Connecticut
}

Goldsmith, Richard, Stratigraphic names in the New London area, southeastern Connecticut: a revision: this report.

Rope Ferry Gneiss adopted and assigned to Waterford Group (new name) as uppermost of three formations. Over lies New London Gneiss of Waterford with its Joshua Rock Member and overlying unnamed granodiorite gneiss member; underlies unnamed schist in Hunts Brook.

\title{
Roza Member (redefined) \\ (of Wanapum Basalt) \\ (of Yakima Basalt Subgroup) \\ (of Columbia River Basalt Group) \\ middle Miocene \\ southeastern Washington and northern Oregon
}

Swanson, D. A., Wright, T. L., Hooper, P. R., and Bentley, R. D., 1979, Revisions in stratigraphic nomenclature of the Columbia River Basalt Group: U.S. Geological Survey Bulletin 1457-G, 59 p.

Geographically extended from southeastern Washington into: northern Oregon. Reassigned as one of four members to Wanapum Basalt (new name) of Yakima Basalt Subgroup (now raised in rank) of Columbia River Basalt Group (now redefined). Overlies Frenchman Springs Member and underlies Priest Rapids Member (both now redefined) of Wanapum. Age changed from late Miocene to: middle Miocene. 
Saddle Mountains Basalt (redefined)

(of Yakima Basalt Subgroup)

(of Columbia River Basalt Group)

middle and upper Miocene

southern Washington, northern Oregon, and

northwestern Idaho

Swanson, D. A., Wright, T. L., Hooper, P. R., and Bentley, R. D., 1979, Revisions in stratigraphic nomenclature of the Columbia River Basalt Group: U.S. Geological Survey Bulletin 1457-G, 59 p.

Saddle Mountains Member raised in rank to: Saddle Mountains Basalt and reassigned to Yakima Basalt Subgroup (now raised in rank) of Columbia River Basalt Group (now redefined). Geographically extended from southern Washington into: northern Oregon and northwestern Idaho. Divided into ten members (ascending): Umatilla (now redefined), Wilbur Creek (new name), Asotin (new name), Weissenfels Ridge (new name), Esquatzel (new name), Pomona (now redefined), Elephant Mountain (now redefined), Buford (newly adopted), lce Harbor (newly adopted), and Lower Monumental (new name) Members. Age changed from late Miocene and early Pliocene to: middle and late Miocene.

\section{Saddle Peak Member (here named) \\ (of Topanga Canyon Formation) \\ (of Topanga Group) \\ middle Miocene \\ southern California}

Yerkes, R. F., and Campbell, R. H., 1979, Stratigraphic nomenclature of the central Santa Monica Mountains, Los Angeles County, California: U.S. Geological Survey Bulletin 1457-E, $31 \mathrm{p}$.

Saddle Peak Member adopted as lowermost of three members of Topanga Canyon Formation (new name) of Topanga Group in area east of Malibu Canyon. Conformably over lies Piuma Member (new name) of Sespe Formation; conformably underlies Fernwood Member (new name) of Topanga Canyon.

Sage Breaks Shale (raised in rank and name changed) or

Sage Breaks Member

(of Cody or Carlile Shale)

Upper Cretaceous

eastern Wyoming

Merewether, E. A., Cobban, W. A., and Cavanaugh, E. T., 1979, Frontier Formation and equivalent rocks in eastern Wyoming: The Mountain Geologist, v. 16, no. 3, p. 67-102.

In eastern part of Hanna, southern part of Shirley, and Laramie basins of eastern Wyoming, raised in rank to: Sage Breaks Shale. Overlies Frontier Formation; under lies Niobrara Formation. Elsewhere in Wyoming and in Montana Sage Breaks 
Member (changed from Sage Breaks Shale Member) of Cody or Carlile Shale remains in good usage.

Sandy Pond Amphibolite Member (age changed)

(of Marlboro Formation)

Proterozoic Z, Cambrian, or Ordovician

northeastern Massachusetts

Goldsmith, Richard, Stratigraphic names in the New London area, southeastern Connecticut: a revision: this report.

Age changed from pre-Silurian (Precambrina $Z(?)$ to early Paleozoic) to: Proterozoic Z, Cambrian, or Ordovician.

\section{Sangerville Formation (name adopted)}

Lower and Middle Silurian (Llandoverian to Wenlockian)

central and south-central Maine

Osberg, P. H., 1979, Geologic relationships in south-central Maine, in Skehan, J. S., and Osberg, P. H., editors, The Caledonides in the U.S.A.; Geological excursions in the northeast Appalachians-Contributions to the International Geological Correlation Program (IGCP), Project 27--Caledonide Orogen: Weston, Mass., Boston University, Weston Observatory, p. 37-62.

Sangerville Formation of Ludman and Griffin (1974) adopted. Overlies Vassalboro Formation; underlies Fall Brook Formation of Pankiwskyj and others (1976); correlates as western facies of Waterville Formation; its lower and middle parts correlate with Rangeley Formation of western Maine and its upper part correlates with Perry Mountain Formation of west-central Maine.

San Nicholas Member (name adopted)

(of Vaqueros Formation)

lower Miocene

southern California

Yerkes, R. F., and Campbell, R. H., 1979, Stratigraphic nomenclature of the central Santa Monica Mountains, Los Angeles County, California: U.S. Geological Survey Bulletin 1457-E, 31 p.

Nicholas Formation of Sonneman (1956) adopted as San Nicholas Member, upper of two members of Vaqueros Formation in report area. Conformably overlies Danielson Member of Vaqueros; conformably underlies Encinal Member of Topanga Canyon Formation (both new names).

\section{San Rafael Group (stratigraphic extension)}

Middle Jurassic (Bajocian, Bathonian, and Callovian)

southern Utah and northern Arizona

Peterson, Fred, and Pipiringos, G. N., 1979, Stratigraphic relations of the Navajo Sandstone to Middle Jurassic formations in parts of southern Utah and northern 
Arizona: U.S. Geological Survey Professional Paper 1035-B, 43 p.

Stratigraphically extended to include rocks of underlying Navajo Sandstone from upper part of Glen Canyon Group (both now stratigraphically restricted) formerly thought to intertongue with Carmel Formation of San Rafael (now known to be separated from Navajo by widespread unconformity). Stratigraphic extension includes: in southwestern Utah, Temple Cap Sandstone (now raised in rank from member of Navajo and reassigned to San Rafael) and its Sinawava and White Throne Members (both new names); in south-central Utah and north-central Arizona, Page Sandstone (new name) and its Harr is Wash Tongue (new name) and Thousand Pockets Tongue (formerly assigned to Navajo). San Rafael usage in Colorado and New Mexico remains unchanged.

San Rafael Group (reassignment of its formation) Middle Jurassic (Bajocian through Callovian) Utah, Colorado, Arizona, and New Mexico

Pipiringos, G. N., and Imlay, R. W., 1979, Lithology and subdivisions of the Jurassic Stump Formation in southeastern Idaho and adjoining areas: U.S. Geological Survey Professional Paper 1035-C, 25 p.

Curtis Formation of San Rafael Group reduced in rank to Curt is Member and reassigned to Stump Formation as lower of two named members in north-central and northeastern Utah, northwesternmost Colorado, southwestern Wyoming, and southeastern Idaho, where Curtis is not affiliated with San Rafael. Curtis Formation of San Rafael Group remains in good usage in four corners area of Utah and Colorado; San Rafael usage remains unchanged in Arizona and New Mexico.

\section{Santee Limestone (subdivided)}

middle Eocene (middle and upper Claibornian)

southern South Carolina

Ward, L. W., Blackwelder, B. W., Gohn, G. S., and Poore, R. Z., 1979, Stratigraphic revision of Eocene, Oligocene, and lower Miocene formations of South Carolina: South Carolina Division of Geology Geologic Notes, v. 23, no. 1, p. 2-32.

Divided into (ascending): Moultrie and Cross Members (both new names). Moultrie correlates with Lisbon Formation in Alabama, New Hanover Member of Castle Hayne Formation in southeastern North Carolina, and upper part of Nanjemoy Formation in eastern Virginia. Cross correlates with Gosport Sand of Alabama and with Comfort and Spring Garden Members of Castle Hayne Formation in southeastern North Carolina. Santee overlies Black Mingo Formation and under lies Raysor Formation (now reinstated).

\section{Scituate Granite Gneiss (age changed)}

(of Sterling Plutonic Group)

Proterozoic Z

western Rhode Island and eastern Connecticut 
Goldsmith, Richard, Stratigraphic names in the New London area, southeastern Connecticut: a revision: this report.

Age changed from Mississippian(?) or older to: Proterozoic Z; considered to be approximately equivalent to Potter Hill Granite Gneiss (newly assigned to Sterling Plutonic Group).

\section{Scott Conyon Formation (age changed) \\ Devonian \\ Nevada}

Jones, D. L., Wrucke, C. T., Holdsworth, Brian, and Suczek, C. A., 1979, Greenstone in Devonian Slaven Chert in north-central Nevada, in Geological Survey research 1979: U.S. Geological Survey Professional Paper 1150, p. 81.

Age changed from Early or Middle Cambrian to: Devonian.

\section{Sentinel Granodionite (removed from series) \\ Upper Cretaceous \\ central California}

Bateman, P. C., and Chappell, B. W., 1979, Crystallization, fractionation, and solidification of the Tuolumne Intrusive Series, Yosemite National Park, California: Geological Society of America Bulletin, Part I, v. 90, no. 5, p. 465482.

No longer assigned to Tuolumne Intrusive Series and not reassigned to any other series.

Sespe Formation (member assigned to)

upper Eocene, Oligocene, and lower Miocene

southern California

Yerkes, R. F., and Campbell, R. H., 1979, Stratigraphic nomenclature of the central Santa Monica Mountains, Los Angeles County, California: U.S. Geological Survey Bulletin 1457-E, 31 p.

In Santa Monica Mountains, includes Piuma Member (new name) in its upper part.

\section{Shawsheen Gneiss (age changed)}

Ordovician or Proterozoic Z

northeastern Massachusetts

Goldsmith, Richard, Stratigraphic names in the New London area, southeastern Connecticut: a revision: this report.

Age changed from pre-Silurian to: Ordovician or Proterozoic Z. 
Sheep Bay Granite (age changed)

Eocene(?)

southern Alaska

Tysdal, R. G., and Case, J. E., 1979, Geologic map of the Seward and Blyling Sound quadrangles, Alaska: U.S. Geological Survey Miscellaneous Investigations Series Map I-1150, 12 p. text.

Age changed from Paleozoic(?) to: Eocene(?).

Sheep Pass Formation (age changed)

Upper Cretaceous(?) to middle Eocene (varies)

east-central Nevada

Fouch, T. D., 1979, Character and paleogeographic distribution of Upper Cretaceous(?) and Paleogene nonmarine sedimentary rocks in east-central Nevada, in Armentrout, J. M., Cole, M. R., and TerBest, Harry, Jr., editors, Cenozoic paleogeography of the Western United States: Los Angeles, California, Pacific Section, Society of Economic Paleontologists and Mineralogists, Pacific Coast Paleogeography Symposium 3, p. 97-111.

Over-all age changed from Eocene to: Late Cretaceous(?) to middle Eocene (at type section; varies elsewhere).

\section{Sherwin Drift (name changed) \\ Pleistocene \\ eastern California, eastern Sierra Nevada}

Waitt, R. B., Jr., 1979, Late Cenozoic deposits, landforms, stratigraphy, and tectonism in Kittitas Valley, Washington: U.S. Geological Survey Professional Paper $1127,18 \mathrm{p}$.

Name changed from Sherwin Glaciation or Till to: Sherwin Drift in eastern Sierra Nevada, eastern California; Sherwin Glaciation or Till remains good usage elsewhere in eastern California and in western Nevada.

\section{Shuyak Formation (name adopted) \\ Upper Triassic \\ southwestern Alaska}

Connelly, William, and Moore, J. C., 1979, Geologic map of the northwest side of the Kodiak and adjacent islands, Alaska: U.S. Geological Survey Miscellaneous Field Studies Map MF-1057, 2 sheets.

Shuyak Formation of Connelly (1978) adopted as oldest rocks in map area. Divided into: unnamed lower volcanic member and unnamed upper sedimentary member.

\section{Silver Shield Quartz Latite (here named)}

middle Miocene

central Utah 
Morr is, H. T., and Lovering, T. S., 1979, General geology and mines of the East Tintic mining district, Utah and Juab Counties, Utah: U.S. Geological Survey Professional Paper 1024, 203 p.

Silver Shield Quartz Latite adopted, consisting of dike and flow unit. Dike intrudes Packard Quartz Latite; flow unit overlies Pinyon Creek Conglomerate (new name).

\section{Simi Conglomerate (name adopted)}

Paleocene(?)

southern California

Yerkes, R. F., and Campbell, R. H., 1979, Stratigraphic nomenclature of the central Santa Monica Mountains, Los Angeles County, California: U.S. Geological Survey Bulletin 1457-E, $31 \mathrm{p}$.

Simi Conglomerate of Nelson (1925) adopted and questionably recognized in Santa Monica Mountains. Unconformably(?) overlies Tuna Canyon Formation and conformably underlies Coal Canyon Formation (both new names).

\section{Sinawava Member (here named)}

(of Temple Cap Sandstone)

(of San Rafael Group)

Middle Jurassic (Bajocian)

southwestern Utah

Peterson, Fred, and Pipiringos, G. N., 1979, Stratigraphic relations of the Navajo Sandstone to Middle Jurassic formations in parts of southern Utah and northern Arizona: U.S. Geological Survey Professional Paper 1035-B, 43 p.

Sinawava Member adopted and assigned as lower of two members to Temple Cap Sandstone (now raised in rank from member of Navajo Sandstone and reassigned to San Rafael Group). Overlies Navajo Sandstone of Glen Canyon Group; underlies White Throne Member (new name) of Temple Cap.

\section{Sinepuxent Formation (here named) \\ Pleistocene (middle Wisconsin) \\ Maryland, Virginia, and Delaware, central Delmarva Peninsula}

Owens, J. P., and Denny, C. S., 1979, Upper Cenozoic deposits of the central Delmarva Peninsula, Delaware and Maryland, Chapter A in Surface and shallow subsurface geologic studies in the emerged Coastal Plain of the Middle Atlantic states: U.S. Geological Survey Professional Paper 1067-A, 28 p.

Sinepuxent Formation adopted. Unconformably overlies Omar Formation, Ironshire Formation, Beaverdam Sand, and so-called "Yorktown(?) and Cohansey(?)" Formations (= Pensauken Formation). 


\section{Snaky Conyon Formation (here named) \\ uppermost Mississippian (locally) to Lower Permian \\ east-central Idaho}

Skipp, Betty, Hoggan, R. D., Schleicher, D. L., and Douglass, R. C., 1979, Upper Paleozoic carbonate bank in east-central Idaho--Snaky Canyon, Bluebird Mountain, and Arco Hills Formations and their paleotectonic significance: U.S. Geological Survey Bulletin 1486, 78 p.

Snaky Canyon Formation adopted. Divided into (ascending): Bloom, Gallagher Peak Sandstone, and Juniper Gulch Members (all three new names); Snaky Canyon undivided in White Knob Mountains. Gradationally overlies Bluebird Formation (new name); conformably and abruptly underlies Phosphoria Formation.

Sneech Pond Schist (its affiliation name and its age changed)

(of Blackstone Group)

Proterozoic Z

Rhode Island

Goldsmith, Richard, Stratigraphic names in the New London area, southeastern Connecticut: a revision: this report.

Its affiliation name changed from Blackstone Series to: Blackstone Group. Age of Blackstone and its four formations (Mussey Brook, Quinnville, Sneech Pond, Hunting Hill) changed from Precambrian(?) to: Proterozoic Z.

\section{Solstice Conyon Tongue (here named) \\ (of Conejo Volcanics) \\ (of Topanga Group) \\ middle Miocene \\ southern California}

Yerkes, R. F., and Campbell, R. H., 1979, Stratigraphic nomenclature of the central Santa Monica Mountains, Los Angeles County, California: U.S. Geological Survey Bulletin 1457-E, 31 p.

Solstice Canyon Tongue adopted as middle of three new tongues of Conejo Volcanics. Conformably overlies Latigo Canyon Breccia Member of Calabasas Formation (both new names); conformably underlies Malibu Bowl Member (new name) of Conejo.

\section{Spoon Formation (geographic extension)}

(of Kewanee Group)

Middle Pennsylvanian

Illino is and Indiana

Solem, Alan, and Yochelson, E. L., 1979, North American Paleozoic land snails, with a summary of other Paleozoic nonmarine snails: U.S. Geological Survey Professional Paper 1072, 42 p.

Geographically extended from Illinois into: Indiana. 


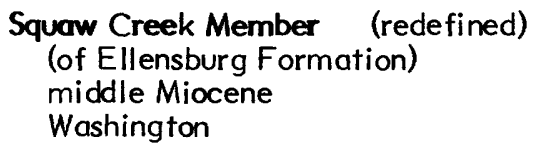

Swanson, D. A., Wright, T. L., Hooper, P. R., and Bentley, R. D., 1979, Revisions in stratigraphic nomenclature of the Columbia River Basalt Group: U.S. Geological Survey Bulletin 1457-G, 59 p.

Squaw Creek Diatomite Bed of Frenchman Springs Member (now redefined) of Yakima Basalt Subgroup (now raised in rank) of Columbia River Basalt Group (now redefined), raised in rank to: Squaw Creek Member, replacing Quincy Diatomite Bed (now abandoned) and reassigned to: Ellensburg Formation.

\section{Steamboat Hills Rhyolite (age changed) upper Pliocene(?) and Ple istocene western Nevada}

Silberman, M. L., White, D. E., Keith, T. E. C., and Dockter, R. D., 1979, Duration of hydrothermal activity at Steamboat Springs, Nevada, from ages of spatially associated volcanic rocks: U.S. Geological Survey Professional Paper 458-D, 14 p.

Age changed from Pleistocene to: late Pliocene(?) and Pleistocene.

\section{Sterling Plutonic Group (redefined) \\ Proterozoic Z \\ eastern Connecticut and western Rhode Island}

Goldsmith, Richard, Stratigraphic names in the New London area, southeastern Connecticut: a revision: this report.

Divided into (ascending): Ponaganset Geniss (newly assigned), Potter Hill Granite Gneiss (newly assigned) approximately equivalent to Scituate Granite Gneiss (previously assigned), Ten Rod Granite Gneiss (not mentioned in report but previously assigned), and Hope Valley Alaskite Gneiss (previously assigned). Age changed from Mississippian(?) or older to: Proterozoic Z.

\section{Stokes Canyon Breccia Member (here named) (of Calabasas Formation) \\ (of Topanga Group) \\ middle Miocene \\ southern California}

Yerkes, R. F., and Campbell, R. H., 1979, Stratigraphic nomenclature of the central Santa Monica Mountains, Los Angeles County, California: U.S. Geological Survey Bulletin 1457-E, $31 \mathrm{p}$.

Stokes Canyon Breccia Member adopted as one of six new members of Calabasas Formation (new name) of Topanga Group. Prominently interbedded with Calabasas in Stokes Canyon area. 


\section{Stump Formation (redefined)}

Middle and Upper Jurassic (Callovian and Oxfordian)

southeastern Idaho, northeastern and north-central Utah, southwestern Wyoming, and northwesternmost Colorado

Pipiringos, G. N., and Imlay, R. W., 1979, Lithology and subdivisions of the Jurassic Stump Formation in southeastern Idaho and adjoining areas: U.S. Geological Survey Professional Paper 1035-C, 25 p.

Lithology changed from Stump Sandstone to: Stump Formation. In southeastern Idaho, northeastern and north-central Utah, southwestern Wyoming, and northwesternmost Colorado (now geographically extended), divided into (ascending): Curtis Member (reduced in rank; Middle Jurassic, Callovian) and Redwater Member (reassigned from Sundance Formation; Upper Jurassic, Oxfordian); Curtis and Redwater usage remains unchanged elsewhere. Age of Stump changed everywhere from Late Jurassic to: Middle and Late Jurassic (Callovian and Oxfordian).

\section{Sturgis Formation (age changed) \\ Middle and Upper Pennsylvanian (Des Moinesian and Missourian) western Kentucky}

Douglass, R. C., 1979, The distribution of fusulinids and their correlation between the Illino is Basin and the Appalachian Basin, in Palmer, J. E., and Dutcher, R. R., editors, Depositional and structural history of the Pennsylvanian System of the Illino is Basin, Part 2: Invited papers, Field trip 9/Ninth International Congress of Carboniferous Stratigraphy and Geology, Urbana, Illinois, 1979: Illinois State Geological Survey Guidebook Series 15a, p. 15-20.

Age of Sturgis changed from Late Pennsylvanian to: Middle and Late Pennsylvanian (Des Moinesian and Missourian). Age of its Providence Limestone, Anvil Rock Sandstone, and Madisonville Limestone Members changed from Late Pennsylvanian to: Middle Pennsylvanian (Des Moinesian); age of its Carthage Limestone Member remains Late Pennsylvanian (Missourian).

\section{Sundance Formation (its member reassigned)}

Middle and Upper Jurassic (Bajocian through Oxfordian)

northeastern and north-central Utah, southwestern Wyoming, southeastern Idaho, and northwesternmost Colorado

Pipiringos, G. N., and Imlay, R. W., 1979, Lithology and subdivisions of the Jurassic Stump Formation in southeastern Idaho and adjoining areas: U.S. Geological Survey Professional Paper 1035-C, 25 p.

In northeastern and north-central Utah, southwestern Wyoming, southeastern Idaho, and northwesternmost Colorado, Redwater Shale Member of Sundance renamed: Redwater Member and reassigned to: Stump Formation as upper of two named members. Redwater Shale Member of Sundance remains good usage elsewhere in Colorado and Wyoming and in western South Dakota. Sundance remains in good usage elsewhere in Wyoming. Utah, and Colorado and in Montana, South Dakota, and Nebraska. 


\author{
Surrise Peak Monzonite Porphyry (here named) \\ middle Oligocene \\ central Utah
}

Morris, H. T., and Lovering, T. S., 1979, General geology and mines of the East Tintic mining district, Utah and Juab Counties, Utah: U.S. Geological Survey Professional Paper 1024, 203 p.

Sunrise Peak Monzonite Porphyry adopted; occupies Sunrise Peak stock and Gough sill.

\title{
Sweetheart Mountain Member (name adopted) (of Collinsville Formation) Middle Ordovician or older north-central Connecticut and western Massachusetts
}

Stanley, R. S., 1980, Adoption, redefinition, and extended use of the name Collinsville Formation and its members and related formations in Connecticut and Massachusetts: this report.

Sweetheart Mountain Member of Collinsville Formation of Stanley (1964) adopted as upper of two named members of Collinsville. Correlated with upper part of Cobble Mountain Formation; overlies Bristol Member of Collinsville; underlies Straits Schist.

\section{Tampa Limestone (geographically restricted) lower Miocene northern Florida and southern Georgia}

Ward, L. W., Blackwelder, B. W., Gohn, G. S., and Poore, R. Z., 1979, Stratigraphic revision of Eocene, Oligocene, and lower Miocene formations of South Carolina: South Carolina Division of Geology Geologic Notes, v. 23, no. 1, p. 2-32.

In southern South Carolina, Tampa Limestone geographically restricted and replaced by Edisto Formation (now reinstated as used by Malde, 1959). Edisto correlated with Tampa of Florida and Georgia and Belgrade Formation of southeastern North Carolina. Tampa Limestone or Formation remains unchanged in Florida and Georgia.

\section{Tassajara Formation (age changed) \\ lower Pliocene \\ central California}

Sarna-Wojcicki, A. M., Bowman, H. W., and Russell, P. C., 1979, Chemical correlation of some late Cenozoic tuffs of northern and central Califomia by neutron activation analysis of glass and comparison with X-ray fluorescence analysis: U.S. Geological Survey Professional Paper 1147, 15 p.

Age changed from Pliocene or Pleistocene to: early Pliocene based on Berggren's 1972 Cenozoic time scale. 
Tatnic Hill Formation (age changed)

(of Putnam Group)

Ordovician, Cambrian, or Proterozoic Z

eastern Connecticut

Goldsmith, Richard, Stratigraphic names in the New London area, southeastern Connecticut: a revision: this report.

Age changed from Middle(?) Ordovician or older to: Ordovician, Cambrian or Proterozoic Z.

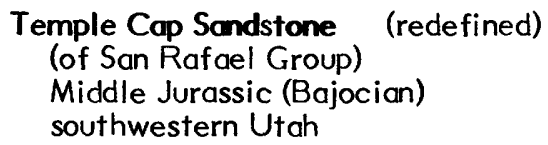

Peterson, Fred, and Pipiringos, G. N., 1979, Stratigraphic relations of the Navajo Sandstone to Middle Jurassic formations in parts of southern Utah and northern Arizona: U.S. Geological Survey Professional Paper 1035-B, 43 p.

Temple Cap Member removed from Navajo Sandstone (now stratigraphically restricted), raised in rank to Temple Cap Sandstone, and reassigned as basal formation of San Rafael Group in southwestern Utah. Divided into (ascending): Sinawava and White Throne Members (both new names). Overlies Navajo Sandstone of Glen Canyon Group; underlies Carmel Formation of San Rafael. Age changed from Jurassic to: Middle Jurassic (Bajocian).

Ten Rod Gronite Geniss (age changed)

(of Sterling Plutonic Group)

Proterozoic Z

western Rhode Island and eastern Connecticut

Goldsmith, Richard, Stratigraphic names in the New London area, southeastern Connecticut: a revision: this report.

Age changed from Mississippian(?) or older to: Proterozoic Z.

Thimble Limestone Member (here named)

(of Carrara Formation)

Lower Cambrian

southeastern California and southern Nevada

Palmer, A. R., and Halley, R. B., 1979, Physical stratigraphy and trilobite biostratigraphy of the Carrara Formation (Lower and Middle Cambrian), southern Great Basin: U.S. Geological Survey Professional Paper 1047, 131 p.

Thimble Limestone Member adopted as one of nine members of Carrara Formation. Conformably overlies Eagle Mountain Shale Member (new name) of Carrara; underlies Echo Shale Member (new name) of Carrara. 


\title{
Thorp Gravel (name adopted) \\ Pliocene \\ central Washington
}

Waitt, R. B., Jr., 1979, Late Cenozoic deposits, landforms, stratigraphy, and tectonism in Kittitas Valley, Washington: U.S. Geological Survey Professional Paper $1127,18 \mathrm{p}$.

Thorp Drift of Porter (1975, 1976) adopted and renamed Thorp Gravel. Unconformably overlies Ellensburg Formation; underlies Quaternary deposits; correlates with Ringold Formation.

\author{
Thousond Pockets Tongue (redefined) \\ (of Page Sandstone) \\ (of San Rafael Group) \\ Middle Jurassic (Bathonian) \\ south-central Utah nd north-central Arizona
}

Peterson, Fred, and Pipiringos, G. N., 1979, Stratigraphic relations of the Navajo Sandstone to Middle Jurassic formations in parts of southern Utah and northern Arizona: U.S. Geological Survey Professional Paper 1035-B, 43 p.

Removed from Navajo Sandstone (now stratigraphically restricted) and reassigned as upper of two tongues to Page Sandstone (new name) of San Rafael Group (now stratigraphically extended). Overlies Judd Hollow Tongue and underlies unnamed upper member, both of Carmel Formation of San Rafael Group. Age changed from Middle and Late(?) Jurassic to: Middle Jurassic (Bathonian).

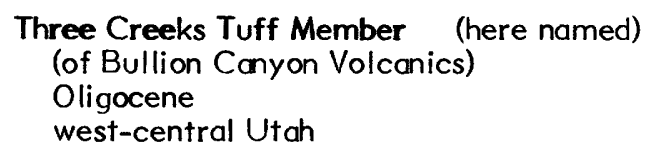

Steven, T. A., Cunningham, C. G., Naeser, C. W., and Mehnert, H. H., 1979, Revised stratigraphy and radiometric ages of volcanic rocks and mineral deposits in the Marysvale area, west-central Utah: U.S. Geological Survey Bulletin 1469, $40 \mathrm{p}$.

Three Creeks Tuff Member adopted and assigned to Bullion Canyon Volcanics. Overlies and underlies unnamed lower and upper part of Bullion Canyon, respectively. Replaces part of Dry Hollow Formation (now abandoned).

\section{Tintic Delmar Latite (here named) \\ (of Laguna Springs Volcanic Group) \\ middle Oligocene \\ central Utah}

Morris, H. T., and Lovering, T. S., 1979, General geology and mines of the East Tintic mining district, Utah and Juab Counties, Utah: U.S. Geological Survey Professional Paper 1024, 203 p. 
Tintic Delmar Latite adopted and assigned to Laguna Springs Volcanic Group (now: raised in rank) as uppermost of three formations. Overlies Pinyon Queen Latite. (new name) of Laguna Springs; under lies Pinyon Creek Conglomerate (new name).

\author{
Tintic Mountain Volcanic Group (here named) \\ middle Oligocene \\ central Utah
}

Morris, H. T., and Lovering, T. S., 1979, General geology and mines of the East Tintic mining district, Utah and Juab Counties, Utah: U.S. Geological Survey" Professional Paper 1024, 203 p.

Tintic Mountain Volcanic Group adopted. Divided into (ascending): Copperopolis, Latite Ridge, and Big Canyon Latites (all three new names). Unconformably" overlies Packard Quartz Latite; unconformably underlies North Standard Latite: (new name) of Laguna Springs Volcanic Group (now raised in rank).

Topanga Group (raised in rank and subdivided)

middle Miocene

southern California

Yerkes, R. F., and Campbell, R. H., 1979, Stratigraphic nomenclature of the central Santa Monica Mountains, Los Angeles County, California: U.S. Geologica' Survey Bulletin 1457-E, 31 p.

In Santa Monica Mountains (its type area), raised in rank to Topanga Group: formation rank remains good usage elsewhere. As group, divided intc (ascending): Topanga Canyon Formation (new name), with its three new members in area east of Malibu Canyon and with its one new member in area west of Malibu Canyon; Conejo Volcanics, with its three new tongues; and Calabasas Formation (new name), with its six new members.

\title{
Topanga Conyon Formation (here named) (of Topanga Group) middle Miocene southern California
}

Yerkes, R. F., and Campbell, R. H., 1979, Stratigraphic nomenclature of the central Santa Monica Mountains, Los Angeles County, California: U.S. Geologica' Survey Bullet in 1457-E, $31 \mathrm{p}$.

Topanga Canyon Formation adopted as lowermost of three formations of Topanga Group (now raised in rank in Santa Monica Mountains, its type area). East of Malibu Canyon, includes (ascending): Saddle Peak, Fernwood, and Cold CreelMembers (all new names); west of Malibu Canyon, includes Encinal Member (new. name).

Trancas Formation (here named)

lower and middle Miocene

southern California 
Yerkes, R. F., and Campbell, R. H., 1979, Stratigraphic nomenclature of the central Santa Monica Mountains, Los Angeles County, California: U.S. Geological Survey Bulletin 1457-E, 31 p.

Trancas Formation adopted. Unconformably(?) overlies Catalina Schist; unconformably underlies and interfingers with Monterey Shale; interfingers with Zuma Volcanics (new name).

\section{Tuna Canyon Formation (here named) \\ Upper Cretaceous \\ southern California}

Yerkes, R. F., and Campbell, R. H., 1979, Stratigraphic nomenclature of the central Santa Monica Mountains, Los Angeles County, California: U.S. Geological Survey Bulletin 1457-E, 31 p.

In Santa Monica Mountains of southern California, Tuna Canyon Formation adopted, replacing Chico Formation (now geographically restricted from coastal southern California); Tuna Canyon geographically restricted to area north of Malibu Coast fault. Overlies(?) Santa Monica Slate or unnamed conglomerate; unconformably(?) underlies Coal Canyon Formation (new name) or intervening Simi(?) Conglomerate.

\section{Tungsten Hills Quartz Monzonite (age changed)}

Triassic

east-central California

Bateman, P. C., 1979, Cross section of the Sierra Nevada from Madera to the White Mountains, central California: Geological Society of America Map and Chart Series MC-28E, 2 sheets, 4 p. text.

Age changed from Cretaceous to: Triassic.

Tunnel Spring Tuff (age refined)

Oligocene

southwestern Utah

Rowley, P. D., Steven, T. A., Anderson, J. J., and Cunningham, G. C., 1979, Cenozoic stratigraphic and structural framework of southwestern Utah: U.S. Geological Survey Professional Paper 1149, 22 p.

Age changed from Tertiary to: Oligocene.

\section{Tuolumne Intrusive Series (subdivided)}

lower Upper Cretaceous

central California

Bateman, P. C., and Chappell, B. W., 1979, Crystallization, fractionation, and solidification of the Tuolumne Intrusive Series, Yosemite National Park, 
California: Geological Society of America Bulletin, Part I, v. 90, no. 5, p. 465482.

Now divided into: unnamed quartz diorite of May Lake, unnamed tonalites of Glacier Point (formerly eastern part of Sentinel Granodiorite, no longer assigned to Tuolumne or reassigned to any other serjes) and Graying Lake, unnamed granodiorite of Kuna Crest, Half Dome Granodiorite (previously named Half Dome Quartz Monzonite), Cathedral Peak Granodiorite (previously named Cathedral Peak Granite), and Johnson Granite Porphyry.

\section{Tyringham Gneiss (age changed) \\ Proterozoic $Y$ \\ western Massachusetts}

Ratcliffe, N. M., and Hatch, N. L., Jr., 1979, A traverse across the Taconide zone in the area of the Berkshire massif, western Massachusetts, in Skehan, J. S., and Osberg, P. H., editors, The Caledonides in the U.S.A.; Geological excursions in the northeast Appalachians--Contributions to the International Geological Correlation Program (IGCP), Project 27-Caledonide Orogen: Weston, Mass., Boston University, Weston Observatory, p. 175-224.

Age changed from Precambrian to: Proterozoic Y.

\section{Umatilla Member (redefined)}

(of Saddle Mountains Basalt)

(of Yakima Basalt Subgroup)

(of Columbia River Baslt Group)

middle Miocene

southeastern Washington, northeastern Oregon, and northwestern Idaho

Swanson, D. A., Wright, T. L., Hooper, P. R., and Bentley, R. D., 1979, Revisions in stratigraphic nomenclature of the Columbia River Basalt Group: U.S. Geological Survey Bulletin 1457-G, 59 p.

Umatilla Flow renamed Umatilla Member and reassigned to Saddle Mountains Basalt (now redefined) of Yakima Basalt Subgroup (now raised in rank) of Columbia River Basalt Group (now redefined). Geographically extended from south-central Washington into: southeastern Washington, northeastern Oregon, and northwestern Idaho. Overlies sedimentary deposits; underlies Pomona Member (now redefined) of Saddle Mountains.

\section{Unalaska Formation (member assigned to) lower Miocene and older southwestern Alaska, Unalaska Island}

Lankford, S. M., and Hill, J. M., 1979, Stratigraphy and depositional environment of the Dutch Harbor Member of the Unalaska Formation, Unalaska Island, Alaska: U.S. Geological Survey Bulletin, 1457-B, 14 p. 
Dutch Harbor Member (new name) adopted and assigned to Unalaska Formation as its only named member, conformably overlying and underlying unnamed lower and upper volcanic sequences of Unalaska.

\section{Uyak Formation (age changed) \\ Lower Cretaceous \\ south-central Alaska}

Fisher, M. A., 1979, Structure and tectonic setting of the continental shelf southwest of Kodiak Island, Alaska: American Association of Petroleum Geologists Bulletin, v. 63, no. 3, p. 30I-310.

Age changed from Triassic to: Early Cretaceous.

\section{Uyak Complex (redefined) \\ Lower Cretaceous \\ south-central Alaska}

von Huene, Roland, Moore, G. W., and Moore, J. C., 1979, Cross section, Alaska Peninsula-Kodiak Island-Aleutian Trench: Geological Society of America Map and Chart Series MC-28A, 2 sheets.

Geographically and stratigraphically restricted to exclude Lower Jurassic blueschist formerly included in its lower part; name changed from Uyak Formation to: Uyak Complex (now considered tectonic melange).

\section{Vantage Member (redefined) \\ (of Ellensburg Formation) \\ middle Miocene \\ south-central Washington}

Swanson, D. A., Wright, T. L., Hooper, P. R., and Bentley, R. D., 1979, Revisions in stratigraphic nomenclature of the Columbia River Basalt Group: U.S. Geological Survey Bulletin 1457-G, 59 p.

Vantage Sandstone Member renamed: Vantage Member and reassigned from Yakima Basalt (now raised in rank to Yakima Basalt Subgroup) of Columbia River Basalt Group (now redefined) to: Ellensburg Formation as lowermost of three members. Overlies Grande Ronde Basalt (newly adopted) and underlies Wanapum Basalt (new name), both of Yakima. Age changed from late Miocene to: middle Miocene.

\section{Vaqueros Formation (subdivided) lower Miocene (varies) southern California}

Yerkes, R. F., and Campbell, R. H., 1979, Stratigraphic nomenclature of the central Santa Monica Mountains, Los Angeles County, California: U.S. Geological Survey Bulletin 1457-E, 31 p. 
In Santa Monica Mountains, divided into (ascending): Danielson and San Nicholas Members (both newly adopted). Conformably overlies Sespe Formation; conformably underlies Encinal Member of Topanga Canyon Formation (both new names). Age varies from Oligocene and Miocene to: early Miocene only. Vaqueros Formation or Sandstone remains good usage elsewhere in California.

\section{Vassalboro Formation (age changed) \\ uppermost Ordovician(?) and Lower Silurian (Llandoverian) south-central Maine}

Osberg, P. H., 1979, Geologic relationships in south-central Maine, in Skehan, J. S., and Osberg, P. H., editors, The Caledonides in the U.S.A.; Geological excursions in the northeast Appalachions-Contributions to the International Geological Correlation Program (IGCP), Project 27--Caledonide Orogen: Weston, Mass., Boston University, Weston Observatory, p. 37-62.

Age changed from Silurian and Devonian to: latest Ordovician(?) and Early Silurian (Llandoverian).

\section{Wanapum Basalt (here named)}

(of Yakima Basalt Subgroup)

(of Columbia River Basalt Group)

middle Miocene

southern Washington, northern Oregon, and northwestern Idaho

Swanson, D. A., Wright, T. L., Hooper, P. R., and Bentley, R. D., 1979, Revisions in stratigraphic nomenclature of the Columbia River Basalt Group: U.S. Geological Survey Bulletin 1457-G, 59 p.

Wanapum Basalt adopted and assigned as middle of three formations to Yakimc Basalt Subgroup (now raised in rank) of Columbia River Basalt Group (now redefined). Divided into four members (oldest to youngest): Eckler Mountain (new name), Frenchman Springs, Roza, and Priest Rapids (all three now redefined) Members. Conformably and disconformably overlies Grande Ronde Basalt (newly; adopted) of Yakima or overlies Vantage Member (now renamed and reassigned) of Ellensburg Formation; generally conformably underlies Saddle Mountains Basal (now redefined) of Yakima.

\section{Wando Formation (name adopted) \\ upper Pleistocene south-central South Carolina}

McCartan, Lucy, Weems, R. E., and Lemon, E. M., Jr., The Wando Formatior (upper Pleistocene) in the Charleston, South Carolina, area: this report.

Wando Clays and Sands of Sloan (1908) adopted and redefined as Wandc Formation. Unconformably overlies Cooper Formation or Santee Limestone: underlies Holocene eolian deposits. Includes deposits formerly included ir Pamlico, "Princess Ann," and "Silver Bluff." 
Wapiti Formation (geographic extension and age changed) lower or middle Eocene northwestern Wyoming

Pierce, W. G., 1979, Clastic dikes of Heart Mountain fault breccia, northwestern Wyoming, and their significance: U.S. Geological Survey Professional Paper II33, $35 \mathrm{p}$.

Geographically extended into Heart Mountain fault area of northwestern Wyoming; replaces Lamar River Formation (now geographically restricted). Age changed from early middle Eocene to: early or middle Eocene. Wapiti Formation of Sunlight Group of Absaroka Volcanic Supergroup remains good usage elsewhere in northwestern Wyoming and in south-central Montana.

\author{
Washingtan Gneiss （geographic extension) \\ Precambrian \\ northwestern Connecticut
}

Harwood, D. S., 1979, Bedrock geologic map of the Norfolk Quadrangle, Connecticut: U.S. Geological Survey Geologic Quadrangle Map GQ-1518.

Geographically extended from Massachusetts and Rhode Island into: northwestern Connecticut.

\title{
Washingtan Gneiss (age changed) \\ Proterozoic $Y$ \\ western Massachusetts
}

Ratcliffe, N. M., and Hatch, N. L., Jr., 1979, A traverse across the Taconide zone in the area of the Berkshire massif, western Massachusetts, in Skehan, J. S., and Osberg, P. H., editors, The Caledonides in the U.S.A.; Geological excursions in the northeast Appalachians-Contributions to the International Geological Correlation Program (IGCP), Project 27-Caledonide Orogen: Weston, Mass., Boston University, Weston Observatory, p. 175-224.

Age changed from Precambrian to: Proterozoic Y.

\section{Waterford Group (here named) \\ Proterozoic Z \\ eastern Connecticut}

Goldsmith, Richard, Stratigraphic names in the New London area, southeastern Connecticut: a revision: this report.

Waterford Group adopted and divided into (ascending): Mamacoke Formation (newly assigned), New London Gneiss with its Joshua Rock Member (name changed from Joshua Rock Gneiss Member) and overlying unnamed granodiorite gneiss member (all newly assigned), and Rope Ferry Gneiss (new name here adopted and assigned). Water ford over lies Plainfield Formation and underlies unnamed schist in Hunts Brook. 


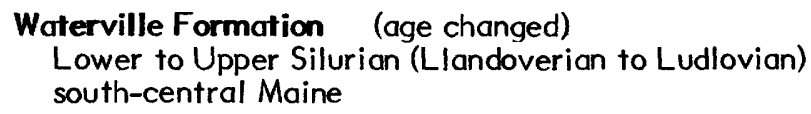

Osberg, P. H., 1979, Geologic relationships in south-central Maine, in Skehan, J. S., and Osberg, P. H., editors, The Caledonides in the U.S.A.; Geological excursions in the northeast Appalachians--Contributions to the International Geological Correlation Program (IGCP), Project 27--Caledonide Orogen: Weston, Mass., Boston University, Weston Observatory, p. 37-62.

Age changed from Silurian and Devonian to: Early to Late Silurian (Llandoverian to Ludlovian).

\section{Weissenfels Ridge Member (here named) \\ (of Saddle Mountains Basalt) \\ (of Yakima Basalt Subgroup) \\ (of Columbia River Basalt Group) \\ middle Miocene \\ southeastern Washington and northwestern Idaho}

Swanson, D. A., Wright, T. L., Hooper, P. R., and Bentley, R. D., 1979, Revisions in stratigraphic nomenclature of the Columbia River Basalt Group: U.S. Geological Survey Bulletin 1457-G, 59 p.

Weissenfels Ridge Member adopted and assigned as one of ten members to: Saddle Mountains Basalt (now redefined) of Yakima Basalt Subgroup (now raised in rank) of Columbia River Basalt Group (now redefined). Conformably overlies Asotin Member (new name) and unconformably underlies Elephant Mountain Member (now redefined), both of Saddle Mountains.

\section{Wesselman Tongue (name adopted) \\ (of Kope Formation) \\ Upper Ordovician \\ southwestern Ohio}

Pojeta, John, Jr., 1979, The Ordovician paleontology of Kentucky and nearby states-introduction: U.S. Geological Survey Professional Paper 1066-A, 48 p.

Wesselman Tonque of Ford (1967) adopted as upper of two named units in Kope Formation (lower unit is Grand Avenue Member). Overlies North Bend Tongue of Fairview Formation; intertongues and underlies main body of Fairview Formation.

\section{Whipple Cave Formation (name adopted) Upper Cambrian and lowermost Ordovician(?) eastern Nevada}

Cook, H. E., and Taylor, M. E., 1977, Comparison of continental slope and shelf environments in the Upper Cambrian and lowest Ordovician of Nevada: Society of Economic Paleontologists and Mineralogists Special Publication 25, p. 51-81. 
Whipple Cave Formation of Kellogg (1963) adopted. Coeval with lower part of Hales Limestone; underlies House Limestone (coeval with upper part of Hales Limestone).

\author{
White Throne Member (here named) \\ (of Temple Cap Sandstone) \\ (of San Rafael Group) \\ Middle Jurassic (Bajocian) \\ southwestern Utah
}

Peterson, Fred, and Pipiringos, G. N., 1979, Stratigraphic relations of the Navajo Sandstone to Middle Jurassic formations in parts of southern Utah and northern Arizona: U.S. Geological Survey Professional Paper 1035-B, 43 p.

White Throne Member adopted and assigned as upper of two members to Temple Cap Sandstone (now raised in rank from member of Navajo Sandstone and reassigned to San Rafael Group). Overlies Sinawava Member (new name) of Temple Cap; under lies Carmel Formation of San Rafael.

\author{
Wilbur Creek Member (here named) \\ (of Saddle Mountains Basalt) \\ (of Yakima Basalt Subgroup) \\ (of Columbia River Basalt Group) \\ middle Miocene \\ southeastern Washington and northwestern Idaho
}

Swanson, D. A., Wright, T. L., Hooper, P. R., and Bentley, R. D., 1979, Revisions in stratigraphic nomenclature of the Columbia River Basalt Group: U.S. Geological Survey Bulletin 1457-G, 59 p.

Wilbur Creek Member adopted and assigned as one of ten members to: Saddle Mountains Basalt (now redefined) of Yakima Basalt Subgroup (now raised in rank) of Columbia River Basalt Group (now redefined). Conformably overlies Umatilla Member (now redefined) of Saddle Mountains or unconformably overlies Priest Rapids Member (now redefined) of Wanapum Basalt (new name); unconformably under lies Asotin Member (new name) of Saddle Mountains.

\author{
Yakima Basalt Subgroup (raised in rank and redefined) \\ (of Columbia River Basalt Group) \\ lower, middle, and upper Miocene \\ southern Washington, northern Oregon, and \\ northwestern Idaho
}

Swanson, D. A., Wright, T. L., Hooper, P. R., and Bentley, R. D., 1979, Revisions in stratigraphic nomenclature of the Columbia River Basalt Group: U.S. Geological Survey Bulletin 1457-G, 59 p.

Yakima Basalt raised in rank to: Yakima Basalt Subgroup of Columbia River Basalt Group (now redefined). Divided into three formations (ascending): Grande Ronde Basalt (newly adopted); Wanapum Basalt (new name) with its Eckler Mountain (new name), Frenchman Springs, Roza, and Priest Rapids (all three now redefined) Members; and Saddle Mountains Basalt (now redefined) with its 
Umatilla (now redefined), Wilbur Creek (new name), Asotin (new name), Weissenfels Ridge (new name), Esquatzel (new name), Pomona (now redefined), Elephant Mountain (now redefined), Buford (newly adopted), lce Harbor (newly adopted), and Lower Monumental (new name) Members. Geographically extended from southern Washington and northern Oregon into: northwestern Idaho. Age changed from middle and late Miocene and early Pliocene to: early, middle, and late Miocene.

Yorktown Formation (geographic extension) (of Chesapeake Group, North Carolina only) lower and middle(?) Pliocene eastern North and eastern South Carolinas

Blackwelder, B. W., and Ward, L. W., 1979, Stratigraphic revision of the Pliocene deposits of North and South Carolina: South Carolina Division of Geology Geologic Notes, v. 23, no. I, p. 33-49.

Geographically extended from Virginia, Maryland, and North Carolina into: eastern South Carolina, replacing Duplin Marl or Formation (now abandoned) and "Macks Formation" of local usage. Not assigned to Chesapeake Group in South Carolina as Chesapeake not extended into South Carolina.

\section{Zabriskie Quartzite (new member assigned to) Lower Cambrian southern Nevada and southeastern California}

Palmer, A. R., and Halley, R. B., 1979, Physical stratigraphy and trilobite biostratigraphy of the Carrara Formation (Lower and Middle Cambrian), southern Great Basin: U.S. Geological Survey Professional Paper 1047, 131 p.

Emigrant Pass Member adopted as uppermost unit of Zabriskie Quartzite; underlies Eagle Mountain Shale Member (new name) of Carrara Formation.

\section{Zuma Volcanics (here named) lower and middle Miocene southern California}

Yerkes, R. F., and Campbell, R. H., 1979, Stratigraphic nomenclature of the central Santa Monica Mountains, Los Angeles County, California: U.S. Geological Survey Bulletin 1457-E, 31 p.

Zuma Volcanics adopted. Overlies unnamed schist; interbedded with Trancas Formation (new name) and lower part of Monterey Shale; underlies Monterey Shale. 


\section{REFERENCES CITED}

Berggren, W. A., 1972, A Cenozoic time-scale--Some implications for regional geology and paleobiogeography: Lethaia, v. 5 , no. 2, p. 195215.

Brown, G. D., Jr., and Lineback, J. A., 1966, Lithostratigraphy of Cincinnatian Series (Upper Ordovician) in southeastern Indiana: American Association of Petroleum Geologists Bulletin, v. 50, no. 5, p. 1018-1032.

Connelly, William, 1978, Uyak Complex, Kodiak Islands, Alaska: A Cretaceous subduction complex: Geological Society of America Bulletin., v. 89, no. 1, p. 755-769.

Cook, E. F., 1957, Geology of the Pine Valley Mountains, Utah: Utah Geological and Mineralogical Survey Bulletin 58, III p.

Cook, E. F., 1960a, Breccia blocks (Mississippian) of the Welcome Springs area, southwest Utah: Geological Society of America Bulletin, v. 71, no. 11 , p. 1709-1712.

Cook, E. F., 1960b, Geologic atlas of Utah-Washington County: Utah Geological and Mineralogical Survey Bulletin 79, $119 \mathrm{p}$.

DuBar, J. R., 1969, Biostratigraphic significance of Neogene macrofossils from two dug ponds, Horry County, South Carolina: South Carolina Division of Geology Geologic Notes, v. 13, no. 3, p. 67-80.

DuBar, J. R., Johnson, H. S., Jr., Thom, Bruce, and Hatchell, W. O., 1974, Neogene stratigraphy and morphology, south flank of the Cape Fear Arch, North and South Carolina, in Post-Miocene stratigraphy, central and southern Atlantic Coastal Plain: Utah State University Press, Logan, Utah, p. 139-173.

Ford, J. P., 1967, Cincinnatian geology in southwest Hamilton County, Ohio: American Association of Petroleum Geologists Bulletin, v. 51, no. 6 , p. 918-936.

Gates, R. M., 1975, The bedrock geology of the South Canaan quadrangle: Connecticut Geological and Natural History Survey Quadrangle Report 32,33 p.

Hepburn, J. C., 1972a, Geology of the metamorphosed Paleozoic rocks in the Brattleboro area, Vermont: Cambridge, Mass., Harvard University, unpub. Ph.D. thesis, $342 \mathrm{p}$. 
Hepburn, J. C., 1972b, Geology of the Guilford dome area, southeastern Vermont: New England Intercollegiate Geological Conference, 64th, Annual Meeting, Burlington, Vermont, October 13-15, Guidebook for field trips in Vermont: p. 231-243.

Heron, S. D., Jr., Robinson, G. C., and Johnson, H. S., Jr., 1965, Clays and opal-bearing claystones of the South Carolina Coastal Plain: South Carolina Division of Geology Bulletin 31, 66 p.

Hooper, P. R., 1974, Petrology and chemistry of the Rock Creek flow, Columbia River basalt, Idaho: Geological Society of America Bulletin, v. 85 , no. 1, p. 15-26.

Jillson, W. R., 1919, The Kendrick Shale; a new calcareous fossil horizon in the coal measures of eastern Kentucky: Kentucky Department of Geology and Forestry, Series V, Mineral and Forest Resources of Kentucky, v. 1, no. 2, p. 96-104.

Johnson, H. S., Jr., 1967, Geologic activities in South Carolina during 1966: South Carolina Division of Geology Geologic Notes, v. II, no. 1, p. 1-4.

Jordan, R. R., 1962, Stratigraphy of the sedimentary rocks of Delaware: Delaware Geological Survey Bulletin 9, 51 p.

Jordan, R. R., and others, 1967, Atlantic Coastal Plain Geological Association, Delaware, 8th annual field conference, 1967: Newark, Delaware, University Delaware and Delaware Geological Survey, p. I20.

Kelley, V. C., and Silver, Caswell, 1952, Geology of the Caballo Mountains, with special reference to regional stratigraphy and structure and to mineral resources, including oil and gas: New Mexico University Publications in Geology no. 4, 286 p.

Kellogg, H. E., 1963, Paleozoic stratigraphy of the southern Egan Range, Nevada: Geological Society of America Bulletin, v. 74, no. 6, p. 685708.

Ludman, Allan, and Griffin, J. R., 1974, Stratigraphy and structure of central Maine, in Osberg, P. H., editor, Guidebook for field trips in east-central and north-central Maine: New England Intercollegiate Geological Conference Guidebook no. 66. Trip B-3, D. 154-179.

Mackin, J. H., 1960, Structural significance of Tertiary volcanic rocks in southwestern Utah: American Journal of Science, v. 258, no. 2, D. 81131.

Malde, H. E., 1959, Geoloay of the Charleston phosphate area, South Carolina: U.S. Geological Survey Bulletin 1079, 105 p.

Mattson, P. H., 1960, Geology of the Mayaguez area, Puerto Rico: Geological Society of America Bulletin, v. 71, no. 3, p. 319-362. 
Mattson, P. H., 1973, Middle Cretaceous nappe structures in Puerto Rican ophiolites and their relation to the tectonic history of the Greater Antilles: Geological Society of America Bulletin, v. 84, no. I, p. 21-38.

Molloy, M. W., and Kerr, P. F., 1962, Tushar uranium area, Marysvale, Utah: Geological Society of America Bulletin, v. 73, no. 2, p. 211-236.

Nelson, R. N., 1925, A contribution to the paleontology of the Martinez Eocene of California: California University, Department of Geological Science Bulletin, v. 15, no. 11, p. 397-466.

Pankiwskyj, K. A., Ludman, Allan, Griffin, J. R., and Berry, W. B. N., 1976, Stratigraphic relationships on the southeast limb of the Merrimack synclinorium in central and west-central Maine: Geological Society of America Memoir 146, p. 263-280.

Payne, M. B., 1941, Moreno shale, Panoche Hills, Fresno County, California [abs.]: Geological Society of America Bulletin, v. 52, no. 12, pt. 2, p. 1953-1954.

Payne, M. B., 1951, Type Moreno formation and overlying Eocene strata on the west side of the San Joaquin Valley, Fresno and Merced Counties, California: California Department of Natural Resources, Division of Mines Special Report 9, 29 p.

Porter, S. C., 1975, Weathering rinds as a relative-age criterion: application to subdivision of glacial deposits in the Cascade Range: Geology, v. 3, no. 3, p. $101-104$.

Porter, S. C., 1976, Pleistocene glaciation in the southern part of the North Cascade Range, Washington: Geological Society of America Bulletin, v. 87 , no. I, p. 61-75.

Reinhardt, Juergen, 1974, Stratigraphy, sedimentology, and CambroOrdovician paleogeography of the Frederick Valley, Maryland: Maryland Geological Survey Report of Investigation 23, $74 \mathrm{p}$.

Rice, W. N., and Gregory, H. N., 1906, Manual of the geology of Connecticut: Connecticut Geological and Natural History Survey Bulletin 6, 273 p.

Rodgers, John, and others, 1956, Preliminary geological map of Connecticut: Connecticut Geological and Natural History Survey.

Rodgers, John, Gates, R. M., and Rosenfeld, J. L., 1959, Explanatory text for preliminary geological map of Connecticut, 1956: Connecticut Geological and Natural History Survey Bulletin 84, 64 p.

Schenck, H. G., 1931, Cephalopods of the genus Aturia from western North America: California University, Department of Geological Science Bulletin, v. 19, no. 19, p. 435-490. 
Schmincke, H.-U., 1967, Stratigraphy and petrography of four upper Yakima Basalt flows in south-central Washington: Geological Society of America Bulletin, v. 78, no. II, p. 1385-1422.

Sloan, Earle, 1908, Catalogue of the mineral localities of South Carolina: South Carolina Geological Survey, Series 4, Bulletin 2, 505 p.

Sonneman, H. S., 1956, Geology of the Boney Mountain area, Santa Monica Mountians, California: California University (Los Angeles), M.S. thesis in geology, $73 \mathrm{p}$.

Stanley, R. S.; 1964, The bedrock geology of the Collinsville quadrangle: Connecticut Geological and Natural History Survey Quadrangle Report 16, $99 \mathrm{p}$.

Taubeneck, W. H., 1970, Dikes of Columbia River Basalt in northeastern Oregon, western Idaho, and southeastern Washington, in Gilmour, E. H., and Stradling, Dale, editors, Columbia River Basalt Symposium, 2nd, Cheney, Washington, 1969, Proceedings: Cheney, Eastern Washington State College Press, p. 73-96.

Tuomey, Michael, 1948, Report on the geology of South Carolina: South Carolina Agriculture Survey, Ist Report, 293 p.

Vallier, T. L., 1967, The geology of part of the Snake River Canyon and adjacent areas in northeastern Oregon and western Idaho: Dissertation Abstracts, Section B, v. 28, no. 4, p. 1585.

Waage, K. M., 1968, The type Fox Hills Formation, Cretaceous (Maestrichtion), South Dakota--Part I, Stratigraphy and paleoenvironments: Yale University, Peabody Museum of Natural History Bulletin 27, $175 \mathrm{p}$.

Walker, G. W., 1973, Contrasting compositions of the youngest Columbia River basalt flows in Union and Wallowa, Counties, northeastern Oregon: Geological Society of America Bulletin, v. 84, no. 2, p. 425430.

Wright, T. L., Grolier, M. J., and Swanson, D. A., 1973, Chemical variation related to the stratigraphy of the Columbia River basalt: Geological Society of America Bulletin, v. 84, no. 2, p. 371-386. 


\title{
STRATIGRAPHIC NAMES IN THE NEW LONDON AREA, SOUTHEASTERN CONNECTICUT: A REVISION
}

\author{
By Richard Goldsmith
}

\section{INTRODUCTION}

Recent mapping in eastern Connecticut, reconnaissance mapping in nearby eastern Massachusetts in preparation for a new bedrock geologic map of Massachusetts, and new radiometric age determinations on plutonic rocks in eastern Massachusetts, Rhode Island, and Connecticut have resulted in a need for reassignment of ages and revision of names for rock units in the New London area, southeastern Connecticut, described by Goldsmith (1966, 1976). The changes in age assignments and nomenclature of rock units in the New London area are summarized briefly:

The gneissic Sterling Plutonic Group of eastern Connecticut and western Rhode Island is Proterozoic $Z$ in age. The rocks intruded by the group are then Proterozoic Z or older, but are most likely Proterozoic Z. These are the Plainfield Formation in the lower part of the intruded sequence and metavolcanic and associated metaplutonic rocks, here named the Waterford Group, in the upper part of the intruded sequence. The names Brimfield Schist and Monson Gneiss are considered not appropriate for use in the New London area. The name Brimfield Schist is dropped for this area and an informal name used instead, the schist in Hunts Brook. The name Rope Ferry Gne iss is proposed for rock formerly called Monson Gneiss in this area. The names Potter Hill Granite Gneiss and Hope Valley Alaskite Gneiss used in adjacent Rhode Island are geographically extended into southeastern Connecticut.

\section{AGE ASSIGNMENTS}

The gneissic terrane of southeastern Connecticut is continuous with and part of the eastern basement block or Avalonian terrane of eastern Massachusetts and Rhode Island (Naylor, 1976; Skehan, 1969; Rodgers, 1970; Osberg, 1978) (fig. 2). Although the Avalonian terrane can be divided into an eastern, non-gneissic, and a western, gneissic, part (Goldsmith, 1978), granites in the two parts have a similar range of Proterozoic $Z$ radiometric ages and intrude equivalent rock sequences (Bell and Alvord, 1976; Zartman and Naylor, 1972). A granite of the eastern part is overlain unconformably by fossiliferous Lower Cambrian strata at Hoppin Hill, North Attleboro, Mass. (Skehan, 1969; Bell and Alvord, 1976).

Southeastern Connecticut is part of the western Avalonian terrane dominated by the granite gneisses and gneissic granites of what might be called the Rhode Island batholith forming the core of the Rhode Island anticlinorium (Rodgers, 1970). The granite gneisses here are typified by the Scituate Granite Gneiss and related orthogneisses of the Sterling Plutonic Group (Goldsmith, 1966; Quinn, 1971). Radiometric ages of the Sterling and 


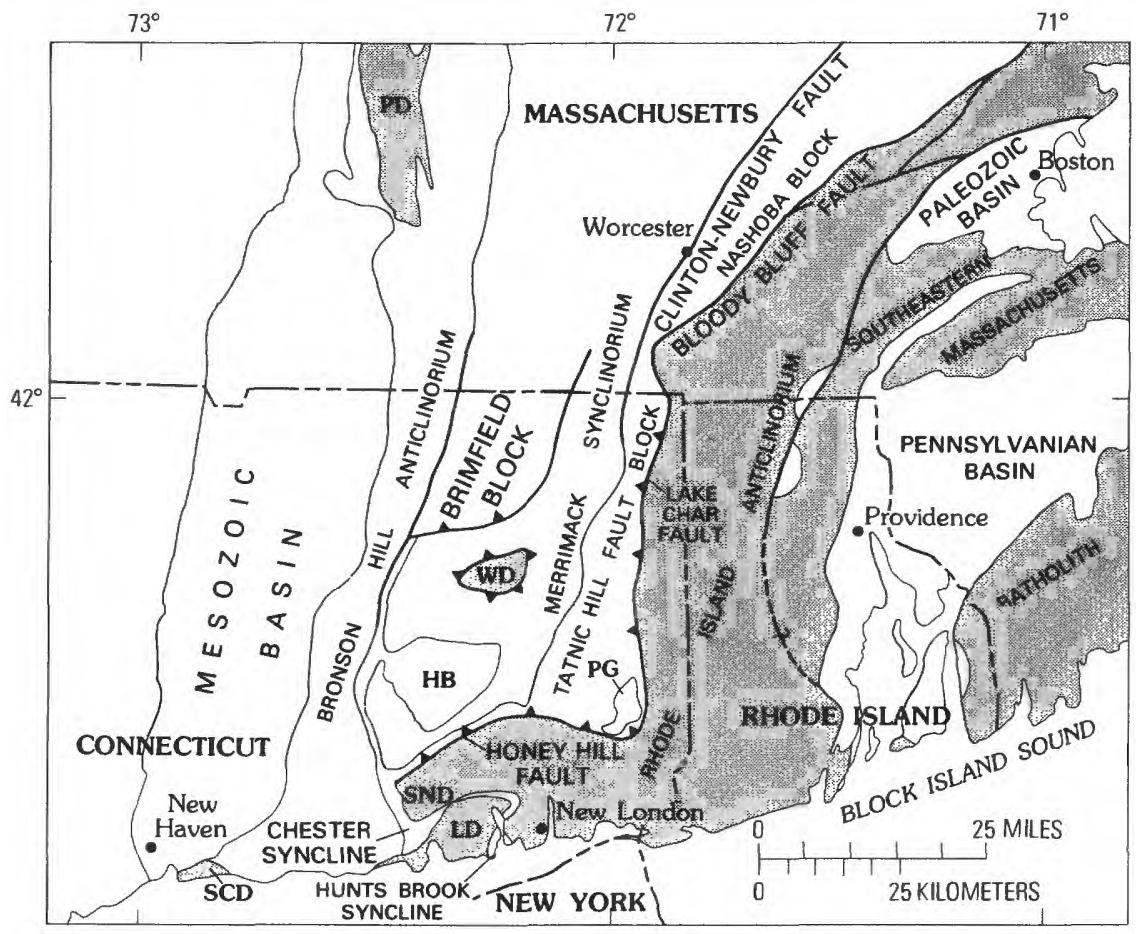

Figure 2.--Index map of eastern Connecticut and adjacent Rhode Island and Massachusetts showing pertinent structural features. Avalonian basement is shaded. HB, Hopyard basin; PG, Preston Gabbro; WD, Willimantic dome; SND, Selden Neck dome; LD, Lyme dome; SCD, Stony Creek dome; PD, Pelham dome. Paleozoic granite not shown. 
other granitic rocks from this terrane, determined by various methods, range from about 600 to 650 m.y. (Zartman and Naylor, 1972; Nelson, 1975; Day, 1968; Hills and Dasch, 1972; R. E. Zartman and R. S. Nlaylor, unpub. data, 1978). A $569+4$ m.y. age by Rb-Sr method (using $87_{R b}=1.39 \times 10-11$ yr. decay constant) on the Northbridge Granite Gneiss, now considered to be equivalent to the Scituate Granite Gne iss and Ponaganset Gneiss, in the northern part of the batholith (Fairbairn and others, 1967) is close to the Proterozoic Z-Cambrian boundary (570 m.y.), uncomfortably close considering the unconformity at Hoppin Hill, Mass. Day (1968) obtained a $638 \pm 42$ m.y. age by $\mathrm{Rb}-\mathrm{Sr}$ methods on the Scituate and other granite gne isses elsewhere in the batholith.

In accordance with the above age determinations, the age of the Sterling Plutonic Group should be changed to Proterozoic Z (table 1), although an Early Cambrian age cannot, perhaps, be ruled out for some of the rocks of the batholith.

Units of the Sterling Plutonic Group are equivalent to the "older plutonic rocks" of Quinn (1971), who assigned them a Mississippian(?) or older age. Quim's principal units are (ascending): Ponaganset Gneiss, Hope Valley Alaskite Gneiss approximately equivalent to Scituate Granite Gneiss, Ten Rod Granite Gneiss, and Potter Hill Granite Gneiss. These units are now considered to be intruded in the following order: Ponaganset Gneiss (oldest), Potter Hill Granite Gneiss approximately equivalent to Scituate Granite Gneiss, Ten Rod Granite Gneiss (not mapped in the New London area, and Hope Valley Alaskite Gneiss (youngest). Age assignments of these units should al so be changed to Proterozoic Z.

The stratified metasedimentary and metavolcanic rocks intruded by the Sterling Plutonic Group must be Proterozoic Z or older. Regional considerations indicate that the intruded rocks are Proterozoic Z (Stewart and Wones, 1974; Osberg, 1978). Therefore, in southeastern Connecticut, the Plainfield Formation and the metavolcanic and metaplutonic rocks, the Waterford Group (see below), are considered to be Proterozoic Z (table I). The possibility that the intrusive relationships of the Sterling Plutonic Group into the Plainfield Formation and Waterford Group are the result of remobilization of the Proterozoic Z-age plutonic rocks during the Paleozoic, thus permitting the Plainfield and Waterford to be Paleozoic in age, is rejected because rocks continuous along strike with the Plainfield in southern Massachusetts and northern Rhode Island are intruded by littlemetamorphosed granites of the same age as those in southern Rhode Island and southeastem Connecticut.

\section{NAME CHANGES}

\section{Sterling Plutonic Group}

The formation names used in Rhode Island for units of the Sterling Plutonic Group (Potter Hill and Hope Valley) are herewith geographically extended into southeastern Connecticut following Feininger (1965). The biotite granite gneiss of the New London area (Goldsmith, 1967a, for 
Table 1. Changes in nomenclature and age assignments,

New London area, southeastern Connecticut (Goldsmith, 1966, 1976)

Name
Western Rhode

(Quinn,

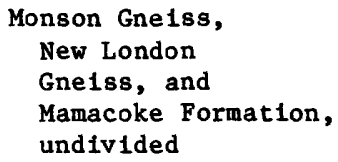

Ordoviclan or older

Ordovician or older

Ordovician or older

Ordovician or older

Ordovician or older

Ordovician or older

Cambrian(?)

pre-Pennsylvanian

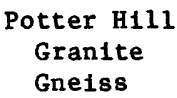


New London area, Connect1cut, and ad facent Rhode Island

\section{Island \\ 1971)}

Age
This paper

Name

schist in Hunts

Brook

Tatnic Hill Formation

Quinebaug Formation

Waterford Group

(here named)

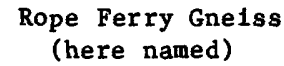

no change

unnamed granodiorite gne1ss member

no change

no change

no change

no change

no change

or older

Mississippian(?)

or older

Mississ1ppian(?)

or older

Mississippian(?)

or older

Mississippian(?)

or older
Proterozolc Z

Ordovician or

Proterozolc Z

Ordovician or

Proterozoic Z

Ordovician,

Cambrian, or

Proterozoic Z

Proterozolc Z

Proterozolc Z

Proterozolc Z

Proterozoic Z

Proterozoic Z

Proterozoic Z

Proterozolc Z

Proterozolc Z

\section{(not mapped in New London area)}

no change

Proterozolc Z

no change

Proterozolc Z 
example) is continuous with Feininger's Potter Hill Granite Gneiss and the alaskite gne iss is continuous with the Hope Valley Alaskite Gne iss.

\section{Water ford Group (here named)}

The group of primarily metavolcanic and metaplutonic plagioclase gneisses and amphibolites constituting the "upper sequence" of Goldsmith (1976) that overlies the Plainfield Formation in the New London area and which consists of (ascending): the Mamacoke Formation; the New London Gne iss with its two members, the Joshua Rock Gneiss (lower) and the unnamed granodiorite gneiss (upper); and the Rope Ferry Gneiss (herein named and described below) is here named the Waterford Group for the town of Waterford where the units are well exposed. Although the formations are distinct in the New London area and to the west (Lundgren, 1963, 1966), the formations are less clearly delineated east and northeast of New London. A group name is convenient to use here and when speaking of the assemblage as a whole. The Waterford Group consists of layered, massive gray plagioclase-rich gneisses (quartz-dioritic and granodioritic) and amphibolite and is variable in thickness, having a maximum of about $3,100 \mathrm{~m}$.

Rocks of the Waterford Group have been considered to be equivalent, all or in part, to the Monson Gneiss of the Bronson Hill anticlinorium (Lundgren, 1966; Goldsmith, 1966; Rodgers, 1970). Indeed, the Waterford Group appears to occupy the same stratigraphic position beneath metavolcanic rocks (Quinebaug Formation). However, some evidence tends to place doubt on such a correlation. Radiometric age determinations on mantling plagioclase gneisses in the Oliverian domes of the Bronson Hill anticlinorium (Naylor, 1976, 1969) and on Monson Gneiss in central Massachusetts (R. E. Zartman, unpub. data, 1978) and Connecticut (Brookins and Methot, 1971) indicate an early Paleozoic age (450 to 460 m.y.) rather than Proterozoic Z. Some preliminary new isotopic data from the New London area (R. P. Wintsch, oral commun.; R. E. Zartman, oral commun.) suggests some resetting of isotopic clocks here.

Two different metavolcanic terrances are juxtaposed in southeastern Connecticut and along strike in eastern Massachusetts, but age relations are conjectural. South and southeast of the Preston Gabbro of Silurian age $(R$. E. Zartman and R. S. Naylor, unpub. data, 1978), metavolcanic rocks assigned to the Waterford Group of Proterozoic $Z$ age are in fault contact with metavolcanic rocks of the Quinebaug Formation of probable early Paleozoic or Proterozoic Z age (see Dixon and Lundgren, 1968). Because of the fault, the stratigraphic relations between the two units cannot be seen. The two are readily distinguished in the field, however, on the basis of style of layering and gross differences in lithology, although some rock types, such as amphibolite, are shared. Rusty-weathering schists present in the Quinebaug are absent in the Waterford Group. The primary distinction is that thin felsic, mafic-poor (alaskitic) layers present in the Waterford Group are not present in the Quinebaug. These layers either were beds of felsic tuff or ash or were thin intrusive sheets. Chemically and mineralogically they are similar to the thicker sill-like masses of Hope Valley Alaskite Gneiss lower in the section. Nothing like them is present in the Quinebaug. This part of the Waterford Group that contains the felsic layers, well displayed in the Preston Gabbro area, is lithologically similar to and occupies 
the same stratigraphic position as controversial Kendal Green Formation (Woburn Formation of LaForge, 1932?) and the overlying amphibolitic Cherry Brook Formation described by Nelson (1974) in the Natick area, Massachusetts (fig. 3).

A juxtaposition of a Proterozoic $Z$ metavolcanic section and a probable lower Paleozoic volcanic section is suggested by Bell and Alvord (1976) in eastern Massachusetts west of Boston where the Middlesex Fells Volcanic Complex, intruded by Dedham Granite, formerly Deham Granodiorite (Wones, 1978), of Proterozoic Z age is overlain, apparently unconformably, by the Greenleaf Mountain and Burlington Formations, and, across the Bloody Bluff fault to the west, by the Marlboro Formation as redefined by Bell and Alvord. The units above the Middlesex Fells in eastern Massachusetts are not intruded by Dedham according to Bell and Alvord. The Marlboro Formation with its Sandy Pond Amphibolite Member occupies the same structural and stratigraphic position beneath the Nashoba Formation and Fish Brook and Shawsheen Gneisses in Massachusetts as does the Quinebaug Formation beneath the Tatnic Hill Formation in Connecticut (fig. 3). The Middlesex Fells Volcanic Complex is correlated by Bell and Alvord with the Cherry Brook Formation of Nelson (1974) and incorporates the Kendal Green Formation, although Bell and Alvord do not recognize the latter as a valid formation.

Juxtaposition and superposition of volcanic sequences of two diffferent ages may be present also in the Bronson Hill anticlinorium. To date, however, all ages obtained from the Oliverian domes and from the Monson Gneiss have been early Paleozoic, about 450 m.y. (Naylor, 1969, 1976; R. E. Zartman, unpub. data, 1978). It seems that the Waterford Group, although containing similar lithologies to those in the Oliverian domes and Monson Gneiss, may be more aptly correlated with lower units such as those exposed in the Pelham dome of east-central Massachusetts for which Naylor and others (1973) have reported a 575 m.y. age. The correlation of rocks of the Waterford Group with the Monson Gneiss and related rocks of the Bronson Hill anticlinorium has been questioned by Naylor $(1976$, p. 422) and Wintsch (1979).

The term Waterford Group is preferred over the term Ivoryton Group used by Lundgren (1966) for rocks equivalent to the Rope Ferry and New London Gneisses of the Waterford Group, and for the Monson Gneiss (Haddam Granite Gneiss) and the overlying Middletown Gneiss of the southern part of the Bronson Hill anticlinorium (Killingworth dome). The Middletown has not been recognized east of the Chester syncline (fig. 2) and is considered by Dixon and Lundgren (1968) to be equivalent to the Quinebaug Formation of the Putnam Group and the Ammonoosuc Volcanics of Middle Ordovician age. Lundgren excluded the Mamacoke Formation from the Ivoryton Group apparently considering that it was more clearly related to the Plainfield Formation than to the formations above. East of New London, however, the Mamacoke appears to have a greater volcanic component than does the primarily metasedimentary Plainfield Formation and is more clearly distinguishable from the underlying Plainfield and less clearly distinguishable from the New London and Rope Ferry Gneisses. I have here included the Mamacoke in the Waterford Group. 


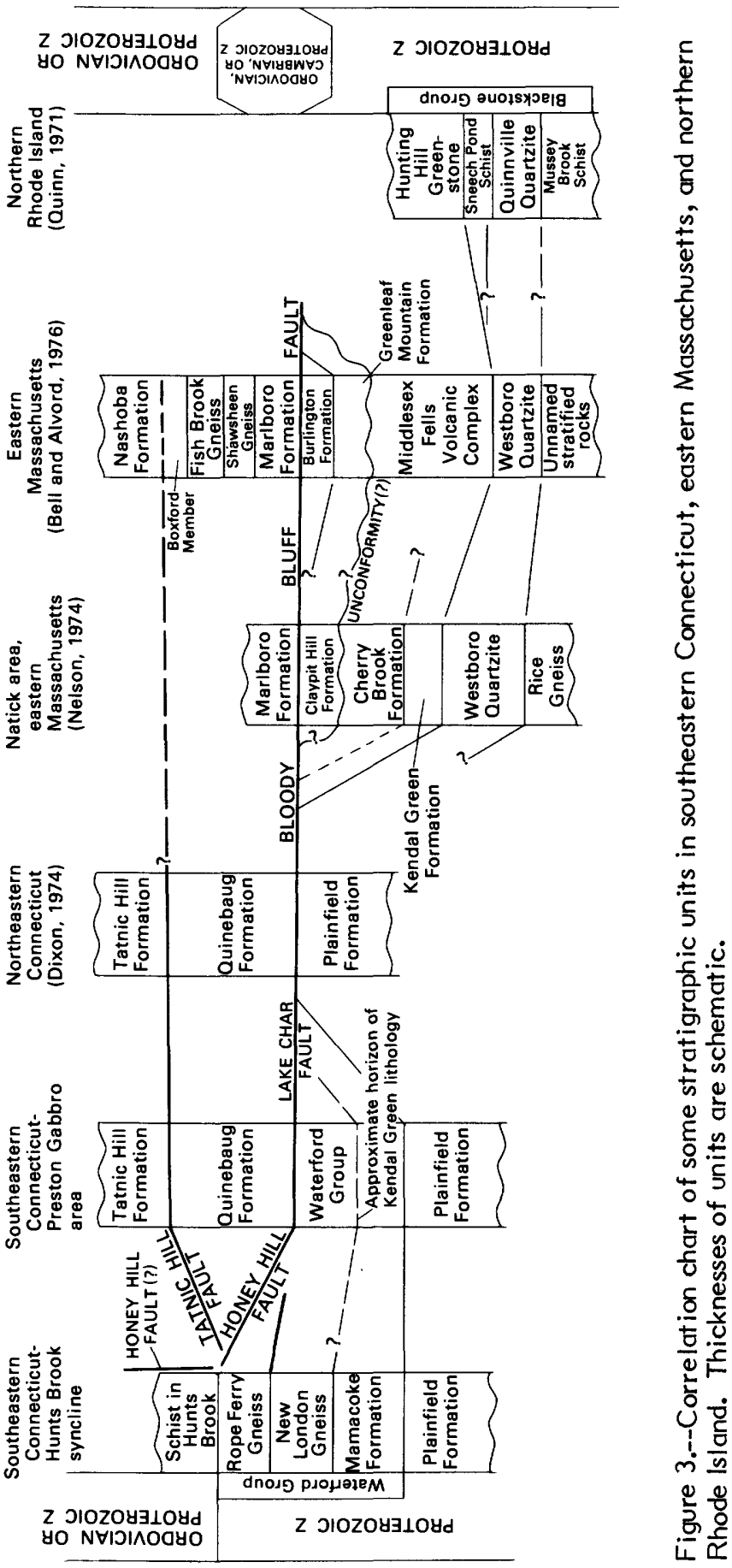




\section{Rope Ferry Gneiss (here named) of the Waterford Group}

The hornblende-biotite-quartz-plagioclase (quartz-dioritic) gneiss in the New London area, formerly called the Monson Gneiss (Goldsmith, 1966) is herewith renamed Rope Ferry Gneiss for extensive exposures between Rope Ferry Road and Jordan Cove in the town of Waterford. Use of the term Monson Gneiss in southeastern Connecticut is not warranted because the name was used here for a specific rock type that resembles only one of the group of related rock types on the Bronson Hill anticlinorium collectively called Monson Gneiss. In addition, the relative ages of the Rope Ferry and Monson Gneisses have been questioned (see above). The lenticularly layered, locally massive, gray-colored Rope Ferry is variable in thickness, having a maximum of about $1,130 \mathrm{~m}$.

\section{Schist in Hunts Brook}

The partly rusty-weathering pelitic schist and gneiss overlying the Rope Ferry Gneiss in the Hunts Brook syncline in the Montville and Niantic quadrangles (Goldsmith, 1967a, b) formerly called Brimfield Schist (Goldsmith, 1966) is renamed informally the schist in Hunts Brook after Hunts Brook in Waterford. The name Brimfield Schist is no longer felt to be applicable in the New London area for the following reason: J. D. Peper and M. H. Pease, Jr., mapping in south-central Massachusetts and northern Connecticut raised in rank and subdivided the Brimfield Schist of Emerson (1917), renaming it the Brimfield Group (Peper and Pease, 1976). They have shown, with further mapping by R. J. Fahey and M. H. Pease, Jr. (Fahey and Pease, 1978), that the rocks of the Brimfield Group are separated from the other rocks of eastem Connecticut by major thrust faults and a high-angle fault and that this fault block must have moved a considerable distance from its original site. They feel, therefore, that use of the term Brimfield is not justified outside this block.

The stratigraphic and structural position of the schist in Hunts Brook with respect to the underlying Waterford Group is fairly clear. Structurally, it lies above the Rope Ferry Gneiss in a refolded isoclinal synform. The contact of the schist with the Rope Ferry Gneiss is sharp where it can be seen, marked by an abrupt change in lithology. There is no evidence of imbrication, cataclasis, or marked attenuation. In two places a thin quartzite, possibly originally a lenticular basal sand, was seen along the contact. These observations support an interpretation that the contact marks an unconformity, although perhaps a pre-metamorphic fault cannot be ruled out. Whatever the case, rocks equivalent to the Quinebaug Formation and Middletown Gneiss are missing between the schist and the Rope Ferry Gneiss.

The schist in Hunts Brook is lithologically similar to and appears to occupy the same stratigraphic position as pelites of probable early Paleozoic age on the flanks of the Merrimack synclinorium: part of the Tatnic Hill Formation of the Putnam Group and possibly the Collins Hill Formation (Rodgers and others, 1959, p. 47) of the Hopyard basin (fig. 2), equivalent to the Brimfield Schist of Lundgren (1963). The schist in Hunts Brook is shown 
to be continuous with both formations by Lundgren (1963) (Dixon and Lundgren, 1968). Wintsch (1979), however, questions this continuity. Even so, the stratigraphic correlation between the schist in Hunts Brook and the Tatnic Hill and possibly the Collins Hill Formations could still apply even though the physical continuity has been broken by the complex faulting observed by Wintsch. The schist in Hunts Brook does not resemble in texture the schist associated with the Plainfield Formation and does not have the interbedded quartzite and sparse calc-silicate-bearing layers associated with it that the schist of the Plainfield has.

The age of the schist in Hunts Brook is considered to be the same as that of the Tatnic Hill Formation. The Tatnic Hill Formation is almost certainly the equivalent of the upper part of the Nashoba Formation along strike to the north in eastern Massachusetts (see also Barosh, 1977; Barosh, Fahey, and Pease, 1977), despite reservations by Dixon (1976) (fig. 3). The Nashoba Formation is intruded by the Andover Granite, which has been dated recently by $\mathrm{Rb} / \mathrm{Sr}$ methods as Late Ordovician to Early Silurian (R. E. Zartman, unpub. data, 1978, and Handford, 1965). This indicates that the Nashoba and Tatnic Hill are Ordovician or older. A foliated pegmatite in the Tatnic Hill Formation has a discordant $207 \mathrm{~Pb} / 206 \mathrm{~Pb}$ zircon age of 520 m.y. (Zartman and other, 1965) indicating a Cambrian or older age, but the origin and history of the zircons is uncertain. U-Pb concordia plots of a suite of euhedral to subhedral zircons from metavolcanoclastic(?) rocks conformably below the Nashoba Formation in eastern Massachusetts: the Fish Brook and Shawsheen Gneisses, give an age of about 742 m.y. (Olszewski, 1978). This age suggests that the Nashoba and the Tatnic Hil! could be Proterozoic Z. However, zircons from the pre-Dedham Middlesex Fells Volcnaic Complex were probably included in the suite according to Olszewski, so that the age is suspect. The age of the Nashoba Formation, the Tatnic Hill Formation, and the schist in Hunts Brook is considered then to be Ordovician or Proterozoic $Z$. The Quinebaug Formation (see discussion of the Waterford Group) would be of similar age.

\section{REFERENCES CITED}

Barosh, P. J., 1977, Preliminary map showing bedrock geology superposed on an aeromagnetic base map of the Worcester region, Massachusetts, Connecticut, and Rhode Island: U.S. Geological Survey Open-File Map $77-131,46$ p. text.

Barosh, P. J., Fahey, R. J., and Pease, M. H., Jr., 1977, Preliminary compilation of the bedrock geology of the land area of the Boston $2^{6}$ sheet, Massachusetts, Connecticut, Rhode Island, and New Hampshire: U.S. Geological Survey Open-File Map 77-285, 142 p. text.

Bell, K. G., and Alvord, D. C., 1976, Pre-Silurian stratigraphy of northeastern Massachusetts, in Page, L. R., editor, Contributions to the stratigraphy of New England: Geological Society of America Memoir 148, p. 179-216. 
Brookins, D. G., and Methot, R. L., 1971, Geochronologic investigations in south-central Connecticut: I. Pre-Triassic basement rocks [abs]: Geological Society of America Abstracts with Programs, v. 3, no. I, p. 20.

Day, H. W., 1968, Rb-Sr ages of some granites of western Rhode Island: Providence, Rhode Island, Brown University, M.S. thesis.

Dixon, H. R., 1968, Bedrock geologic map of the Danielson quadrangle County, Connecticut: U.S. Geological Survey Geologic Quadrangle Map GQ-696.

Dixon, H. R., 1976, Summary discussion of stratigraphy of eastern Massachusetts and Connecticut, in Page, L. R., editor, Contributions to the stratigraphy of New England: Geological Society of America Memoir 148, p. 277-284.

Dixon H. R., and Lundgren, L. W., Jr., 1968, Structure of eastern Connecticut, in Zen, E-an, and others, editors, Studies of Appalachian geology--northern and maritime: New York, Interscience Publications, p. 219-229.

Emerson, B. K., 1917, The geology of Massachusetts and Rhode Island: U. S. Geological Survey Bulletin 597, 289 p.

Fahey, R. J., and Pease, M. H., Jr., 1978, Structural patterns of eastern Connecticut [abs.]: Geological Society of America Abstracts with Programs, v. 10, no. 2, p. 41-42.

Fairbaim, H. W., Moorbath, S., Ramo, A. O., Pinson, W. H., and Hurley, P. M., 1967, Rb-Sr age of granitic rocks of southeastern Massachusetts and the age of the Lower Cambrian at Hoppin Hill: Earth and Planetary Science Letters, v. 2, no. 4, p. 321-328.

Feininger, Tomas, 1965, Bedrock geologic map of the Ashaway quadrangle, Connecticut-Rhode Island: U.S. Geological Survey Geologic Quadrangle Map GQ-403.

Goldsmith, Richard, 1966, Stratigraphic names in the New London area, Connecticut: U.S. Geological Survey Bulletin 1224-J, 9 p.

Goldsmith, Richard, 1967a, Bedrock geologic map of the Montville quadrangle, New London County, Connecticut: U.S. Geological Survey Geologic Quadrangle Map GQ-609.

Goldsmith, Richard 1967b, Bedrock geologic map of the Niantic quadrangle, New London County, Connecticut: U.S. Geological Survey Geologic Quadrangle Map GQ-575.

Goldsmith, Richard, 1976, Pre-Silurian stratigraphy of the New London area, southeastern Connecticut, in Page, L. R., editor, Contributions to the stratigraphy of New England: Geological Society of America Memoir 148, p. $271-275$. 
Goldsmith, Richard, 1978, Stratigraphy of eastern Massachusetts: progress and problems [abs.]: Geological Society of America Abstracts with Programs, v. 10, no. 2, p. 44-45.

Handford, L. S., 1965, Rb/Sr whole rock age study of the Andover and Chelmsford Granites, Massachusetts, in Variations in isotopic abundances of strontium, calcium, and argon and related topics: Massachusetts Institute of Technology, 13th Annual Progress Report for 1965, U.S. Atomic Energy Commission Contract At(30-1)-1381, MIT-|38|-13, p. $11-14$.

Hills, F. A., and Dasch, E. J., 1972, Rb-Sr study of the Stony Creek Granite, southern Connecticut: Geological Society of American Bulletin, v. 83, no. II, p. 3457-3464.

LaForge, Laurence, 1932, Geology of the Boston area, Massachusetts: U.S. Geological Survey Bulletin 839, 105 p.

Lundgren, L. W., Jr., 1963, The bedrock geology of the Deep River quadrangle: Connecticut Geological and Natural History Survey Quadrangle Report 13, 40 p.

Lundgren, Lawrence, Jr., 1966, The bedrock geology of the Hamburg quadrangle: Connecticut Geological and Natural History Survey Quadrangle Report 19, 41 p.

Naylor, R. S., 1976, Isotopic dating and New England stratigraphy, in Page, L. R., editor, Contributions to the stratigraphy of New England: Geological Society of America Memoir 148, p. 419-425.

Naylor, R. S., 1969, Age and origin of the Oliverian domes, central-western New Hampshire: Geological Society of America Bulletin, v. 80, no. 3, p. 405-427.

Naylor, R. S., Boone, G. M., Boudette, E. L., Ashenden, D. D., and Robinson, Peter, 1973, Pre-Ordovician rocks in the Bronson Hill and Boundary Mountain anticlinoria, New England, U.S.A. [abs.]: American Geophysical Union Transactions, v. 54, p. 495.

Nelson, A. E., 1974, Changes in nomenclature of upper Precambrian to lower Paleozoic(?) formations in the Natick quadrangle, eastern Massachusetts, and their tentative correlations with rocks in Rhode Island and Connecticut: U.S. Geological Survey Bulletin 1395-E, 15 p.

Nelson, A. E., 1975, Bedrock geologic map of the Framingham quadrangle, Middlesex and Worcester Counties, Massachusetts: U.S. Geological Survey Geologic Quadrangle Map GQ-1274.

Olszewski, W. J., Jr., 1978, U-Pb zircon ages from stratified metamorphic rocks in northeastern Massachusetts [abs.]: Geological Society of America Abstracts with Programs, v. 10, no. 2, p. 79. 
Osberg, P. H., 1978, Synthesis of the geology of the northeastern Appalachians, U.S.A., in International Geology of the Caledonides Project 27: Caledonian-Appalachian orogen of the North Atlantic region: Geological Survey of Canada Paper 79-13, p. 137-147.

Peper, J. D., and Pease, M. H., Jr., 1976, Summary of stratigraphy in the Brimfield area, Connecticut and Massachusetts, in Page, L. R., editor, Contributions to the stratigraphy of New England: Geological Society of America Memoir 148, p. 253-270.

Quinn, A. W., 1971, Bedrock geology of Rhode Island: U.S. Geological Survey Bulletin 1295, 68 p.

Rodgers, John, 1970, The tectonics of the Appalachians: New York, WileyInterscience, $271 \mathrm{p}$.

Rodgers, John, Gates, R. M., and Rosenfield, J. L., 1959, Explanatory text for preliminary geological map of Connecticut, 1956: Connecticut Geological and Natural History Survey Bulletin 84, 64 p.

Skehan, J. W., S. J., 1969, Tectonic framework of southern New England and eastern New York, in Kay, Marshall, editor, North Atlantic--geology and continental drift-symposium: American Association of Petroleum Geologists Memoir 12, p. 793-814.

Stewart, D. B., and Wones, D. R., 1974, Bedrock geology of the northern Penobscot Bay area, in New England Intercollegiate Geological Conference-1974, Guidebook: Geology of east-central and northcentral Maine, Orono, Maine, p. 223-239.

Wones, D. R., 1978, Plutonic rocks of eastern Massachusetts [abs.]: Geological Society of America Abstracts with Programs, v. 10, no. 2, p. 91.

Wintsch, R. P., 1979, Recent mapping in the Chester area, Connecticut, and its bearing on the Chester syncline abs.: Geological Society of America Abstracts with Programs, v. II, no., I, p. 60.

Zartman, R. E., and Naylor, R. S., 1972, Structural implications of some UTh- $\mathrm{Pb}$ zircon isotopic ages of igneous rocks in eastern Massachusetts [abs.]: Geological Society of America Abstracts with Programs, v. 4, no. I, p. 54-55.

Zartman, R. E., Snyder, G. L., Stern, T. W., Marvin, R. F., and Buckman, R. C., 1965, Implications of new radiometric ages in eastern Connecticut and Massachusetts: U.S. Geological Survey Professional Paper 525-D, p. DI-DIO. 


\title{
JABEZ SANDSTONE MEMBER: A NEW MEMBER OF THE FORT PAYNE FORMATION (MISSISSIPPIAN), SOUTH-CENTRAL KENTUCKY
}

\author{
By Roy C. Kepferle, Wayne A. Pryor', \\ J. Barry Maynard', and James Harrell '
}

The Fort Payne Formation (Lower Mississippian) of south-central Kentucky is a complex unit consisting predominantly of dolosiltite (granular dolomite in silt-size rhombs), with interbedded limestone, sandstone, and shale. The Fort Payne underlies the limestone and shale of the Salem and Warsaw Formations (Upper Mississippian). Detailed geologic mapping in Kentucky has contributed significantly to our understanding of Early Mississippian sedimentation. Some of the more general stratigraphic paleoenvironmental relationships have been summarized by Pryor and Sable (1974).

Units previously recognized in the Fort Payne of south-central Kentucky are the Knifley Sandstone and Cane Valley Limestone Members (Sedimentation Seminar, 1972) and the New Providence Shale Member (Kepferle and Lewis, 1974).

The Jabez Sandstone Member of the Fort Payne Formation is another sandstone body similar to the Knifley and is here named for exposures $6.5 \mathrm{~km}$ (4 mi) southwest of the town of Jabez, Wayne County, Ky. (fig. 4). The type section is on the south shore of Lake Cumberland near the mouth of Harmon Creek.

The geometry of the Jabez can best be described as a northwesttrending prism (wedging out to the southwest) of vertically stacked sandstone tongues which coalesce in the vicinity of the type section and are intercalated with bioclastic limestone and dolosiltite beds typical of the Fort Payne Formation. The sandstone prism is about $10 \mathrm{~km}(6 \mathrm{mi})$ long, a maximum of $6.5 \mathrm{~km}(4 \mathrm{mi})$ wide, and attains a maximum thickness of $43 \mathrm{~m}$ $(140 \mathrm{ft}) 0.8 \mathrm{~km}(0.5 \mathrm{mi})$ due south of the type section. The sandstone is stratigraphically high in the Fort Payne Formation to the northeast, in places being overlain directly by the Salem and Warsaw Formations. Southwestward, it is found at progressively lower levels in the formation. These general relations can be seen in the map and block diagram shown on the Jabez geologic quadrangle map (Thaden and Lewis, 1966) and in figures 4 and 5.

The Jabez typically consists of medium-grained (size range: very fine to coarse), well-sorted, angular, quartz-rich sand, which commonly contains abundant pelmatozoan plates and fragments and also contains sparse detrital feldspar, rock fragments, and argillaceous matrix. The sandstone is variously cemented with chalcedony, calcite, and, especially, dolomite. It is gray to yellowish gray, dense where fresh, and is yellowish brown to brownish red and friable where weathered. The predominant sedimentary structure is

'Department of Geology, University of Cincinnati, Cincinnati, Ohio 

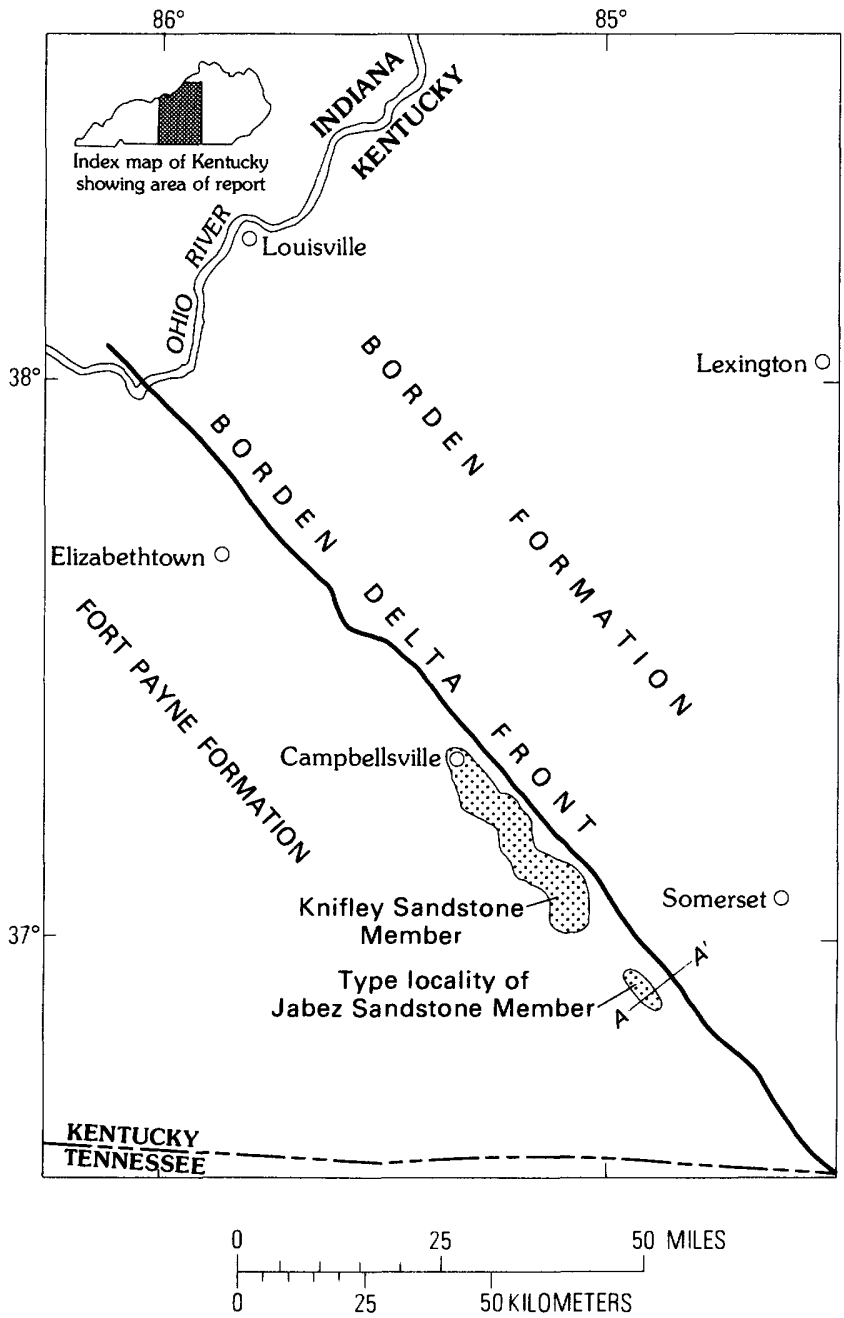

Figure 4.--Index map of south-central Kentucky showing outcrop of the Jabez Sandstone and Knifely Sandstone Members of the Fort Payne Formation and the line of section A-A' (fig. 5). 


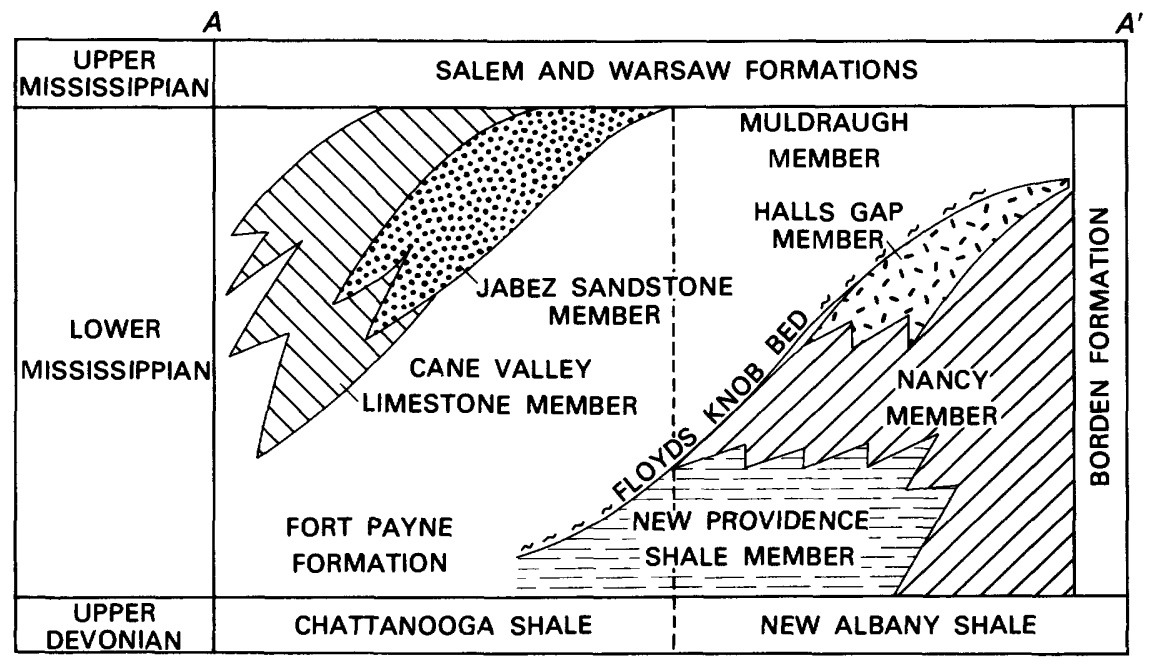

Figure 5.--Diagrammatic cross section across the type locality of the Jabez Sandstone Member illustrating stratigraphic relationships and nomenclature. Location shown in figure 4. 
planar bedding; crossbeds are less common. Burrows along bedding planes are common. Lithologic contacts are sharp between sandstone and dolosiltite and generally gradational between sandstone and limestone.

The Jabez closely resembles the Knifley Sandstone Member of the Fort Payne Formation (Kepferle and Lewis, 1974), which lies $12 \mathrm{~km}(7.5 \mathrm{mi}$ ) to the northwest (fig. 4), but the Jabez is coarser grained and is more extensively intercalated with in limestone tongues projecting from the Cane Valley Limestone Member. Although the Jabez and Knifley are in close stratigraphic, as well as geographic, proximity and probably originated in a similar depositional setting, they are separate and distinct bodies.

The Jabez Sandstone Member is southwest of the terrigenous clastic wedge of the Borden Formation (the Borden delta front of Peterson and Kepferle, 1970, p. D50), and is elongated parallel to the distal edge of the wedge. The Borden units in ascending order are the New Providence Shale Member (also the basal member of the Fort Payne Formation in the southwest), the Nancy Member, the Halls Gap Member, and the Muldraugh Member. This last member is the lithologic and time-stratigraphic equivalent of the rest of the Fort Payne Formation above the New Providence Shale Member. The Muldraugh is marked at its base by a glauconite-rich zone, the Floyds Knob Bed. This bed drops along the clinoform Borden delta front that truncates the Halls Gap and Nancy Members of the Borden Formation and extends into the Fort Payne Formation at the top of the New Providence Shale Member (fig. 5). The importance of the paleotopographic Borden delta front in controlling regional sedimentation patterns is readily indicated by the deposition of the Jabez Sandstone, Knifley Sandstone, and Cane Valley Limestone Members of the Fort Payne Formation.

\section{ACKNOWLEDGMENTS}

The writers are indebted to Robert Lenhart, Michael Short, and Kenneth Eriksson, who assisted us greatly in the field work and the stratigraphic and petrologic analyses. 


\section{MEASURED SECTION}

[Type section of the Jabez Sandstone Member of the Fort Payne Formation measured on the south shore of Lake Cumberland, near the mouth of Harmon Creek, latitude $36^{\circ} 55^{\prime} 20^{\prime \prime} \mathrm{N}$, longitude $84^{\circ} 57^{\prime} / 5^{\prime \prime} \mathrm{W}$, Carter coordinate location: $2000 \mathrm{ft} \mathrm{FSL}, 1000 \mathrm{ft}$ FEL sec. 23-F-55; in the Jabez 7 1/2-minute quadrangle, Wayne County, Ky. Measured by W. A. Pryor, J. B. Maynard, K. Eriksson, J. Harrell, R. Lenhart, and M. Short, using hand level and tape, February 15, 1975.]

\section{Unit}

Description

Thickness in meters (ft)

Mississippian

Salem and Warsaw Formations (incomplete):

12. Limestone, bioclastic, olive-gray to brownishgray; weathers brown ish-black; fossil detritus predominantly bryozoan with minor crinoids; scarce quartz sand grains; cemented with sparry calcite. Contact abrupt .............. I+ (3.3+)

Fort Payne Formation (incomplete):

Jabez Sandstone Member:

11. Sandstone, calcareous, fine-grained, flat-bedded; gray to yellowish-gray and dense where fresh; yellowish-brown to brownish-red and friable where weathered; scattered geodes . . . . . . . . . 4.8

10. Limestone, bioclastic, light-gray to yellowishgray; grainstone; 1- to 2-mm fossil fragments which are predominantly crinoidal with minor bryozoa and brachiopods; common quartz sand grains; sparry calcite cement; planar bedded................

9. Sandstone, as in unit II above, except fine to predominantly medium grained; primary dip direction $220^{\circ} \ldots \ldots \ldots \ldots \ldots \ldots \ldots \ldots . \ldots \ldots . \ldots \ldots$

8. Limestone, as in un it 10, except it is trough crossbedded (trough axis dip direction $20^{\circ}$ ) and contains abundant quartz sand grains .......... 1.8

7 Sandstone as in unit $9 \ldots \ldots \ldots \ldots \ldots$

6. Limestone as in unit $10 \ldots \ldots \ldots \ldots \ldots$

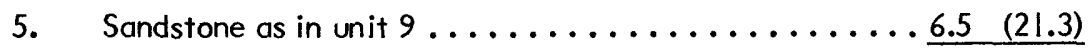

Total Jabez Sandstone Member . . . . . . . . $43.9 \quad$ (144) 
4. Dolosiltite (granular dolomite consisting of silt-size rhombs); cherty, grayish; weathers brown ish-gray; welllaminated planar bedding; quartz silt grains abundant in upper part $\ldots \ldots \ldots \ldots \ldots \ldots \ldots \ldots \ldots \ldots . . . \ldots \ldots$

3. Covered interval, probably dolosiltite $\ldots \ldots \ldots \ldots .7$

2. Limestone, bioclastic; very cherty; grainstone; coarsesand to pebble-size fosisil fragments, predominantly crinoids and brachiopods with some bryozoa; Zoophycus common; contact with underlying dolosiltite erosional with bioclast size decreasing towards top of bed; top marked by glauconitic mudstone $\ldots \ldots \ldots \ldots \ldots \ldots$.

1. Dolosiltite, as in unit 9 , except quartz silt grains scarce; well-laminated planar bedding predominant but in places bedding wavy and discontinuous to indistinct; geodes and Scalarituba abundant; a few thin $(0.1$ to $0.25 \mathrm{~m}$ ) lenses of cherty limestone similar to

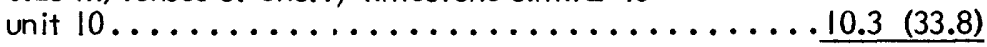

Total Fort Payne Formation (incomplete; section stops (at lake level, altitude $213.1 \mathrm{~m}$ )............6. 61.4 (201.4)

\section{REFEIRENCES CITED}

Kepferle, R. C., and Lewis, R. Q., Sr., 1974, Knifley Sandstone and Cane Valley Limestone: Two new members of the Fort Payne Formation (Lower Mississippian) in south-central Kentucky, in Cohee, G. V., and Wright, W. B., Changes in stratigraphic nomenclature by the U.S. Geological Survey Bulletin 1394-A, p. A63-A70.

Peterson, W. L., and Kepferle, R. C., 1970, Deltaic deposits of the Borden Formation in central Kentucky: U.S. Geological Survey Professional Paper 700-D, p. D49-D54.

Pryor, W. A., and Sable, E. G., 1974, Carboniferous of the Eastern and Interior basin, in Carboniferous of the southeastern United States: Geological Society of America Special Paper 148, p. 281-313.

Sedimentation Seminar, 1972, Sedimentology of the Mississippian Knifley Sandstone and Cane Valley Limestone of south-central Kentucky: Kentucky Geological Survey Report of Investigations 13, 30 p.

Thaden, R. E., and Lewis, R. Q., Sr., 1966, Geologic map of the Jabez quadrangle, Russell and Wayne Counties, Kentucky: U.S. Geological Quadrangle Map GQ-483. 


\title{
THE WANDO FORMATION (UPPER PLEISTOCENE) IN THE CHARLESTON, SOUTH CAROLINA, AREA
}

\author{
By Lucy McCartan, Robert E. Weems, and \\ Earl M. Lemon Jr.
}

\section{LOCATION AND GEOMETRY OF DEPOSIT}

The name Wando Formation is proposed for a system of uppermost Pleistocene coastal deposits in the Charleston, South Carolina, area (fig. 6). The formation has been mapped at the surface and in the subsurface between Georgetown, S.C., and Hilton Head Island, S. C., and extends north and south of this area. The main outcrop belt is typically $12 \mathrm{~km}$ wide and more than $120 \mathrm{~km}$ long. The thickness of the Wando Formation ranges from a veneer of less than $1 \mathrm{~m}$ to almost $25 \mathrm{~m}$ where barrier deposits overlie channel deposits.

The original depositional topography of these deposits is fairly well preserved, and the crests of barriers in the Wando Formation reach a maximum elevation of about $10 \mathrm{~m}$. Backbarrier deposits do not exceed an elevation of about $5 \mathrm{~m}$. The Wando is considered a formation because it is a mappable sequence of deposits that are more closely associated spatially and temporally with each other than with adjacent deposits. The sequence contains several interrelated facies which were deposited unconformably on older deposits and are unconformably overlain by younger deposits. At least three older Pleistocene sequences are present in the South Carolina Coastal Plain.

Delineation of the Wando Formation is based on surface exposures, hundreds of auger-hole samples and logs, geomorphic expression interpreted from maps and air photos, and a few geophysical logs from water wells.

\section{FORMATION NAME}

The Wando Formation is named after the Wando River, a tidal creek northeast of Charleston (fig. 6). In the banks of the Wando River, Wando backbarrier muddy sand and barrier sand tongues are exposed. Modern backbarrier deoposits overlie the Wando in low places. Sloan (1908) referred to two types of deposits as "Wando clays and sands:" red-weathering gray clay and overlying sand, such as along the Ashley River (fig. 6) and Foster Creek, a tributary of the Wando River, which are probably older than the age proposed in this paper for the Wando Formation; and sand containing abundant heavy minerals such as at Simmons Bluff and Wappoo Cut, which is part of the Wando Formation as described in this paper. Kaldor (Kaldor and Cazeau, 1971, and Kaldor, 1969, quoted in Cazeau, 1974) used the name "Wando Bar" for a sand ridge which predates the Wando Formation as described here. Kaldor's "Wando Bar" has not been used elsewhere in the literature, and its use should be formally abandoned.

Sediments of the Wando Formation were formerly mapped as part of the Pamlico Formation (Cooke, 1936; Stephenson, 1912). The Pamlico 


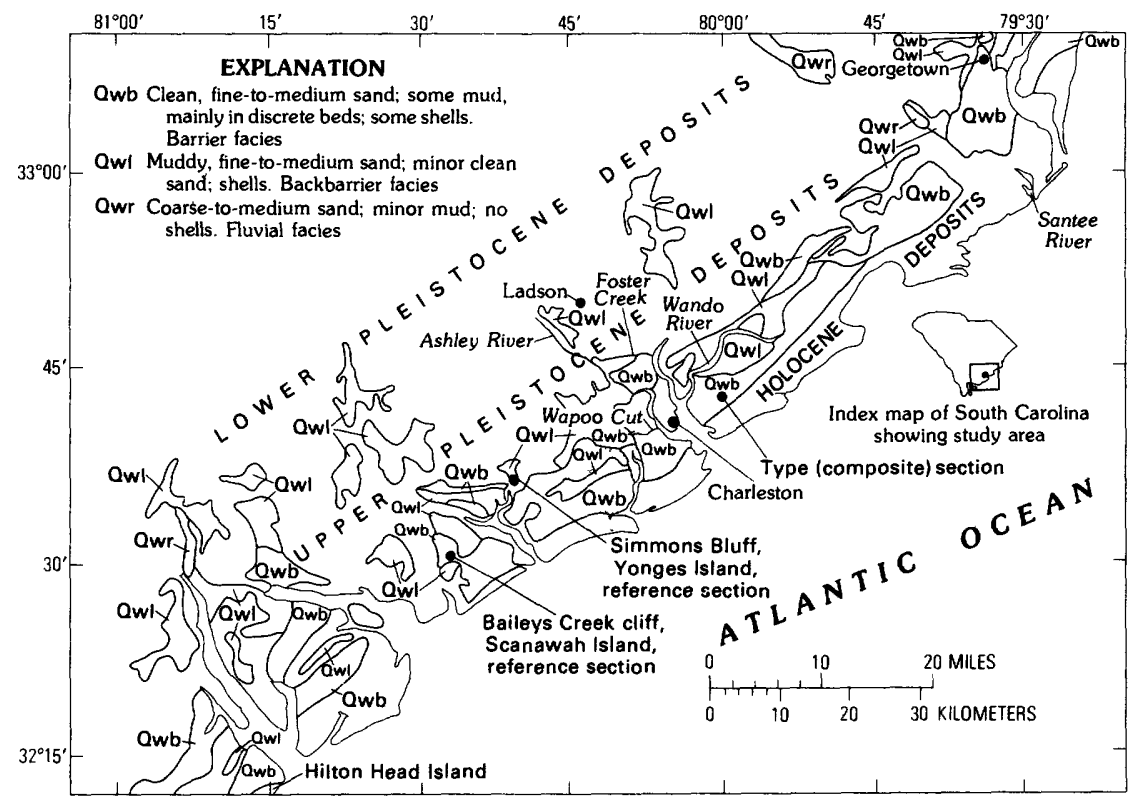

Figure 6.--Geologic sketch map of the Charleston, S.C., area showing the Wando Formation (upper Pleistocene). 
Formation was restricted to marine sediment deposited between $+8 \mathrm{~m}$ and modern sea level. This mor phostratigraphic un it does not fit the distribution of the Wando Formation as mapped herein. Colquhoun (1974) included younger deposits lower and seaward of the "Pamlico" in Cooke's (1953) "Silver Bluff" and "Princess Anne" terraces. These three names, first used in Florida and North Carolina, should not be used for deposits in South Carolina because continuity into South Carolina of the lithostratigraphic units associated with these names in the ir type areas has not been demonstrated.

Malde (1959) included some Wando-age fluvial gravel and sand, exposed along modern streams near Ladson (fig. 6), in his Ladson Formation; the rest of the Ladson Formation appears to be older Ple istocene sediment.

\section{TYPE AUGER HOLE LOG AND REFERENCE SECTIONS}

The type section (fig. 7) is a composite of sections measured in the wall of a sand pit $10 \mathrm{~km}$ east of Charleston (fig. 6) and in a drill hole into the floor of the pit. The pit, now filled with water and slumped sediment, is owned by the Banks Construction Company and is north of Venning Road and east of Route 17-A. It was studied in detailed by Katuna and Tye (1978).

The best natural exposures (fig. 6) are the reference sections at Simmons Bluff, Yonges Island (Wadmalaw Island 7 1/2' quadrangle, $32^{\circ} 41^{\prime \prime} 40^{\prime \prime} \mathrm{N}, 80^{\circ} 13^{\prime} 40^{\prime \prime} \mathrm{W}, 30 \mathrm{~km}$ southwest of Charleston), and the Bailey Creek cliff on the south end of Scanawah Island (Edisto Island 7 1/2' quadrangle, $32^{\circ} 33^{\prime} 30^{\prime \prime} \mathrm{N}, 80^{\circ} 21^{\prime} 45^{\prime \prime} \mathrm{W}$, about $45 \mathrm{~km}$ southwest of Char leston).

The type section and reference sections (fig. 7) consist of several meters of shelly sands and muds over lain by several meters of unfossiliferous well-sorted sand. The lower parts of the three sections record shallow subtidal environments which accompanied rising sea level. The beach and dune environments in which the well-sorted sand in the upper parts of the sections was deposited were present while the sea stood at the highest level for the Wando transgressive cycle (type section and Simmons Bluff), and subsequently prograded seaward during falling sea level (Scanawah Island).

\section{LITHOLOGY AND DEPOSITIONAL. ENVIRONMENTS}

The Wando Formation consists of a variety of sediment types that represent several depositional environments that may be grouped into barrier, backbarrier, and fluvial facies (fig. 6). These sediments and associated environments include river-laid coarse sand and gravel and sparse peat; slightly muddy sand to sandy mud in backbarrier positions; gravel, sand, and plant-bearing clay as inlet channel fill; long, low beach ridges consisting of well-sorted sand roughly parallel to the modern shoreline; and alternating sand and clay as shallow shelf deposits. Shells are found in all but the fluvial units. The shells are of brackish to shallow-marine invertebrates, most of which still live today along the central South Carolina coast (B. W. Blackwelder, U.S. Geological Survey, unpub. data, 1980). The shell material 


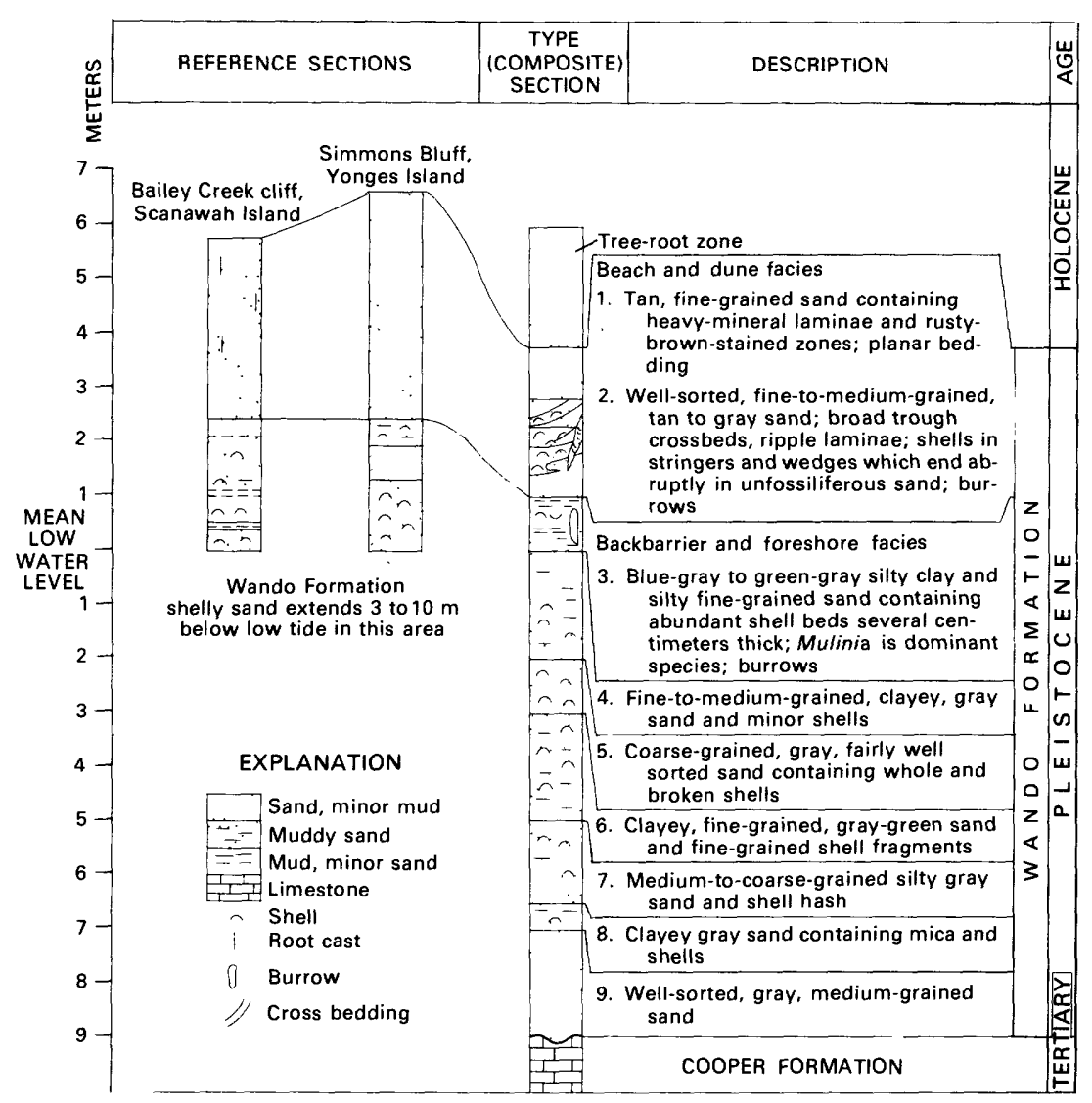

Figure 7.--Type (composite) and reference sections for the Wando Formation. Well-sorted sand facies were deposited in dune or beach environments at highest Wando sea level or during the subsequent regression; mud facies were deposited in backbarrier or foreshore environments during rising sea level. 
is lustrous when first recovered from the outcrop or drill hole but, except for a few species, becomes chalky in a few days when left outdoors.

Sand of the Wando Formation is mainly fine- to medium-grained in the marine facies. The fluvial facies also include fine gravel. Wando sand is primarily quartz; few samples contain more than 10 percent heavy minerals and feldspar. Heavy minerals constitute as much as 26 percent of a beach placer (Force and others, 1978) but typically constitute 3-5 percent. The predominant heavy minerals, in decreasing order of abundance, are ilmenite, hormblende, epidote, garnet, sillimanite, staurolite, zircon, tourmaline, and rutile. Hornblende, epidote, garnet, and feldspar are most abundant south of the mouth of the Santee River (fig. 6).

Clay minerals in the Wando Formation include mixed layer illitesmectite, kaolinite, and illite. In sandy facies, kaolinite is the dominant clay mineral, whereas the mixed-layer material is more abundant in the muddy facies.

\section{CONTACTS}

The Wando Formation unconformably overlies the Cooper Formation, a moderately indurated calcareous mud or sand of late Eocene to late Oligocene age or the middle Eocene Santee Limestone (Ward and others, 1979). The lower contact is irregular, having a gradient of as much as 10 per kilometer. The basal topography appears to have been carved by tidal creeks, probably during Wando time, when sea level was at least $5 \mathrm{~m}$ highter than now. The basal conglomerate of the Wando Formation is a few centimeters thick and includes phosphatic pebbles, limy pebbles of the Cooper Formation, and sparse quartz pebbles. At some localities, the base of the Wando is characterized by pebbly sand as much as $1 \mathrm{~m}$ thick.

Muddy deposits of the Wando Formation that are above sea level commonly have a tan to yellow soil as much as a few centimeters thick. At the same elevations, pre-Wando mud deposits have been weathered longer and have a mottled, deep red-orange soil as much as I I/2 m thick.

The fine- to medium-grained sand bodies are overlain in some places by thin Holocene eolian deposits which have been stabilized by modern forests. Soil development on the sand facies of the Wando Formation is characterized by accumulation of clay films on the grains, humate, removal of all shell material by leaching, oxidation of heavy minerals, and disruption of bedding by insects, other animals, and roots.

\section{AGE}

Corals from five localities in the Wando Formation have been dated by B. J. Szabo (U.S. Geological Survey, unpub. data, 1980) by means of the uranium disequilibrium series method. The calculated ages of the corals, 83,000 to 120,000 years before present, support a latest Pleistocene age for 
the Wando Formation. The presence of the bivalve Anadara brasiliana is also a good indication of latest Pleistocene age (B. W. Blackwelder, U.S. Geological Survey, unpub. data, 1980). A. brasiliana lives today in the shallow water off Charleston and migrated into the area between 450,000 and 200,000 years ago. The rest of the Wando's invertebrate fauna is similar to that living near Charleston today and does not include species which are strictly older Pleistocene forms.

\section{SUMMARY OF DISTINGUISHING CHARACTERISTICS}

The Wando Formation can be distinguished from the older Pleistocene units and Holocene deposits partly on the basis of geomorphic expression. The Wando Formation is the first barrier system landward of the modern shore, and the highest backbarrier deposits are about $5 \mathrm{~m}$ above modern sea level. Holocene deposits are seaward and at lower elevations than Wando deposits; older Pleistocene deposits are farther landward and reach higher elevations than the Wando Formation.

Four lithologic criteria are useful in distinguishing Wando sediment from sediment of other ages.

(1) Most drill holes or surface exposures in the Wando contain abundant shell material, and the shell surface is as lustrous as that of modern shells.

(2) Soils on Wando muds are yellow to orange. Older deposits at the same elevation as the Wando are red or mottled red and gray. Undisturbed modern mud deposits show very little soil development due to weathering.

(3) Wando and modern barrier sand is better sorted than older barrier sand.

(4) A higher percentage of hornblende and epidote is present in the weathered zone of the Wando Formation than in that of the older units; modern deposits are even richer in labile minerals. 


\section{REFERENCES CITED}

Cazeau, C. J., 1974, Heavy minerals of Quaternary sand in South Carolina, in Oaks, R. Q., Jr., and DuBar, J. R., editors, Post-Miocene stratigraphy, central and southern Atlantic Coastal Plain: Logan, Utah, Utah State University Press, p. 174-178.

Colquhoun, D. J., 1974, Cyclic surficial stratigraphic units of the middle and lower Coastal Plains, central South Carolina, in Oaks, R. Q., Jr., and DuBar, J. R., editors, Post-Miocene stratigraphy, central and southern Atlantic Coastal Plain: Logan, Utah, Utah State University Press, p. $179-190$.

Cooke, C. W., 1935, Tentative ages of Pleistocene shorelines: Washington Academy of Science Journal, v. 25, no. 7, p. 331-333.

Cooke, C. W., 1936, Geology of the Coastal Plain of South Carolina: U.S. Geological Survey Bulletin 867, 196 p.

Force, E. R., Grosz, A. E., Zeitz, Isadore, and Loferski, P. J., 1978, Utility of aeroradioactivity maps in the vicinity of Charleston, South Carolina: U.S. Geological Survey Open-File Report 78-587, 50 p.

Kaldor, Michael, 1969, Sedimentology of Wando Bar and related sediments, Georgetown County, South Carolina: Buffalo, State University of New York at Buffalo, unpublished M.A. thesis, $42 \mathrm{p}$.

Kaldor, Michael, and Cazeau, C. J., 197I, Heavy minerals of Wando Bar and Sandy Island (Pleistocene), Georgetown County, South Carolina: South Carolina Division of Geology Geologic Notes, v. 15, no. 2, p. 23-28.

Katuna, M. P., and Tye, R. S., 1978, Backbarrier deposits associated with the Mt. Pleasant barrier, Charleston County, South Carolina [abs.]: Geological Society of America Abstracts with Programs, v. 10, no. 4, p. 172.

Malde, H. E., 1959, Geology of the Charleston phosphate area, South Carolina. U.S. Geological Survey Bulletin 1079, 105 p.

Sloan, Earle, 1908, Catalogue of the mineral localities of South Carolina: South Carolina Geological Survey Bulletin 2, 505 p. (reprinted 1958, by South Carolina Division of Geology).

Stephenson, L. W., 1912, The Coastal Plain of North Carolina: the Cretaceous, Lafayette, and Quaternary formations: North Carolina Geological Survey Bulletin 3, p. 73-171, 258-290.

Ward, L. W., Blackwelder, B. W., Gohn, G. S., Poore, R. Z., 1979, Stratigraphic revision of Eocene, Oligocene, and lower Miocene formations of South Carolina: South Carolina Division of Geology Geologic Notes, v. 23, no. 1, p. 2-32. 


\title{
KENDRICK SHALE MEMBER OF THE BREATHITT FORMATION IN EASTERN KENTUCKY
}

\author{
By Charles L. Rice
}

Jillson (1919) gave the name Kendrick Shale to a fossiliferous marine shale in the middle of what is now called the Breathitt Formation of Early and Middle Pennsylvanian age in eastern Kentucky. The shale is about $8 \mathrm{~m}$ thick at the type locality in the headwaters of Cow Creek, about $10 \mathrm{~km}$ eastsoutheast of Lancer, Floyd County, Ky. (Rice, 1964). It has been recognized by many geologists as an informal unit--the Kendrick Shale of Jillson (1919)-and is one of the most useful stratigraphic units for mapping and correlation in the Breathitt. The base of the Kendrick has been mapped in many parts of eastern Kentucky. This paper redefines and designates the Kendrick Shale as a member of the Breathitt Formation, and, because the type locality is not easily accessible, describes a reference section in an area where the member is thickest and contains marine fossils throughout.

The Kendrick Shale Member is mainly a single upward-coarsening sequence of shale and siltstone; in areas where it is thickest, it may consist of as many as three upward-coarsening sequences. Sandstone is rare in the member except as laminae. The member ranges in thickness from 0 to more than $21 \mathrm{~m}$; it is commonly about $10 \mathrm{~m}$ thick. The basal contact is sharp and is placed at the base of fossiliferous clay shale that over lies coal, underclay, or sandstone. At the base, there is generally a discrete dark-gray carbonaceous shale bed as much as $2 \mathrm{~m}$ thick that contains abundant marine fossils and dense nodular limestone concretions. The upper part of the unit contains sparse silty limestone concretions as much as $2 \mathrm{~m}$ in diameter and thin $(2-4 \mathrm{~cm})$ lenses and nodules of silty siderite. The upper contact is a disconformity placed at the base of an overlying crossbedded sandstone.

The Kendrick Shale Member is a shallow marine bay-fill deposit that, however, does not everywhere contain marine fossils. For purposes of illustrating on fig. 8 the distribution of the Kendrick in eastern Kentucky and some of its local features, the member is divided into two facies: an "openbay" facies that commonly contains abundant mar ine fossils and a "mar ginalbay" facies that contains few or no fossils. Though the marginal-bay facies is generally an upward-coarsening sequence of shale and siltstone, it locally intertongues with and grades into sequences of sandtone, siltstone, and shale that appear to be fluvial in origin. These latter strata are labeled "distributary" on fig. 8. They commonly contain well-preserved plant fossils and are thought to represent deposits of a freshwater distributary system that was active throughout the time of the deposition of the Kendrick. In areas near the distributary system, coarse clastic deposits are locally found even in the open-bay facies as, for example, in the area of the type section (fig. 8) where sandy shale is locally at the base of the Kendrick. Jillson $(1919$, p. 101) describes a bed of fossiliferous blue sandy shale about $60 \mathrm{~cm}$ thick that directly underlies the Kendrick Shale and is separate from it; this bed, which directly overlies a coal bed, is an integral part of the marine unit and is herein included in the Kendrick Shale Member. 


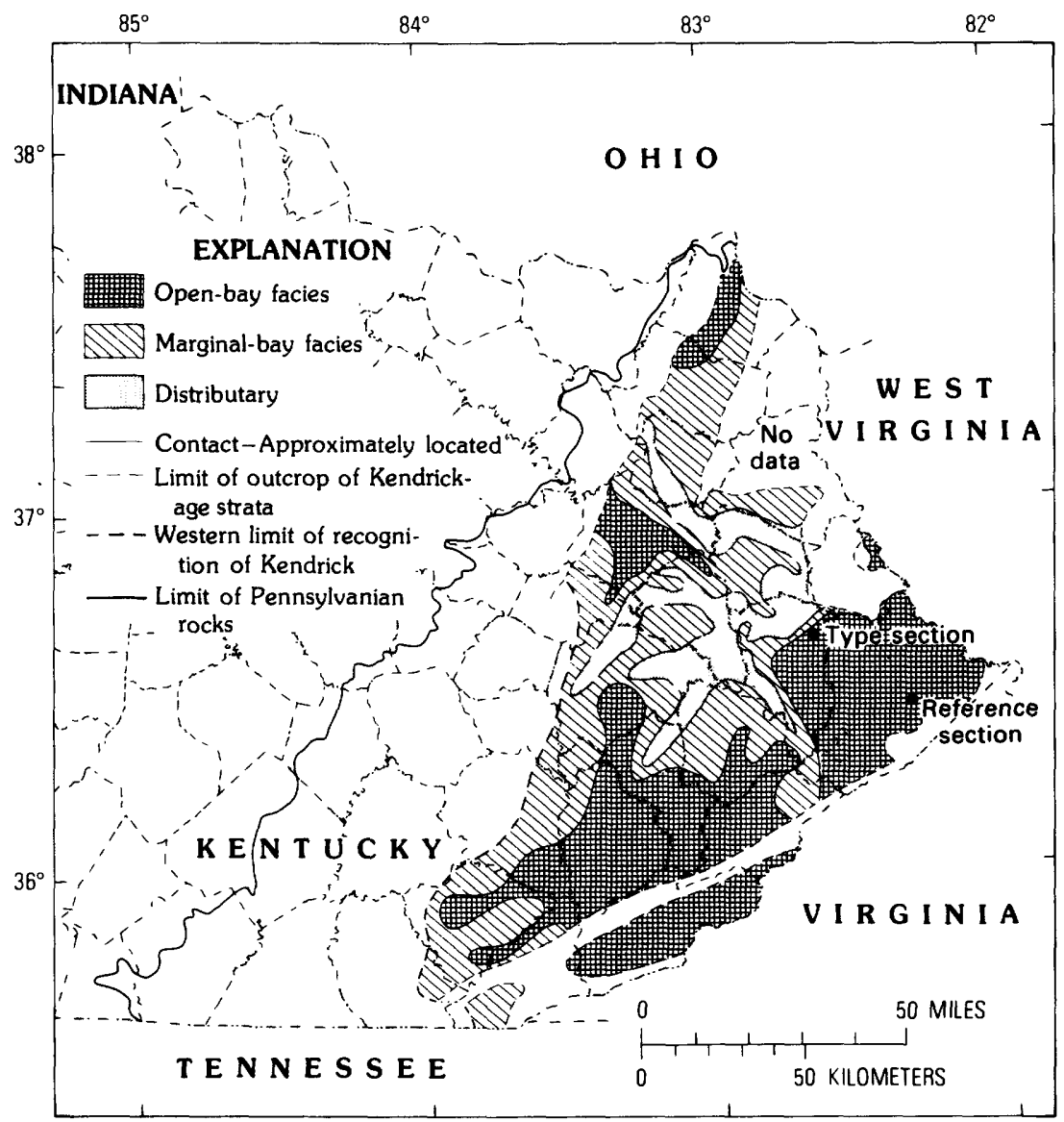

Figure 8.--Map of eastern Kentucky and surrounding areas showing the distribution of the open-bay and marginal-bay facies of the Kendrick Shale Member of the Breathitt Formation. Locations of the type and reference sections of the Kendrick are indicated in the eastern part of the area. The Kendrick is not present in areas shown as "distributary." Data compiled from U.S. Geological Survey Geologic Quadrangle (GQ) maps, reconnaissance mapping, and drill-hole logs. 
The Kendrick Shale Member generally thins toward the northwest. Because of the thinness of the member north of the distributary system shown on fig. 8, the Kendrick has been identified there only by silty limestone concretions; these concretions locally contain marine fossils. In the southwestern part of the area shown in fig. 8, the Kendrick has not been recognized and may not be present.

The Kendrick Shale Member is above the Williamson (Amburgy) coal bed or coal zone and below the coal beds of the Whitesburg coal zone. The Magoffin Member of the Breathitt Formation, a similar marine bay-fill unit, is about $70 \mathrm{~m}$ above the base of the Kendrick in the area of the type section and is about $140 \mathrm{~m}$ above it in the area of the reference section.

The Kendrick Shale Member is in strata equivalent to the Kanawha Formation of West Virginia and is therefore of Middle Pennsylvanian age. Faunal evidence also indicates that it is of Morrowan age (Furnish and Knapp, 1966, p. 297). The member is correlated with the Dingess Limestone of Hennen and Reger (1914) in southern West Virginia by Huddle and Englund (1966, table 4) and has been identified as the Kendrick Shale of Jillson (1919) in the Wise Formation in southwestern Virginia (Miller, 1969, p. 30). Ammonoids similar to those in the Kendrick Shale Member are also found in a marine unit exposed near the outlet of the Beech City reservoir, Tuscarawas County, Ohio (Myron T. Sturgeon, oral commun., 1976); this marine unit is reported to be the "Lowellville (Poverty Run) Limestone Member" of the Pottsville Formation (Henry H. Gray, oral commun., 1976). 


\section{MEASURED SECTION}

[Reference section of the Kendrick Shale Member of the Breathitt Formation. Section measured in Pike County in the head of the Left Fork of Island Creek. Section was measured northeastward along gravel road on the south side of ridge from the gap between the left Fork and Grapevine Creek. Location of the top of section is approximately marked by a red "X" on ridge crest about $0.5 \mathrm{~km}$ southeast of U.S. Highway 460 in the central part of the Lick Creek 7 1/2 minute geologic quadrangle map, GQ-716 (McKay and Alvord, 1969).]

$\underline{\text { Unit }}$

Description

Thickness in meters

Pennsylvanian:

Breathitt Formation (incomplete):

Sandstone, weathers light yellowish brown, fine-to medium-grained, crossbedded, massive weathering; basal beds contain much fine coalified plant debris and casts of large plant remains as much as $1 \mathrm{~m}$ long. Sandstone disconformably over lies clay shale .............. 5+

Kendrick Shale Member:

12. Clay shale, very silty, medium-dark-gray to mediumgray, contains brachiopods and pelecypods and thin concretionary beds of siderite; burrowed siderite bed $0.08 \mathrm{~m}$ thick at base . . . . . . . . . . . . . . . . 1.24

11. Clay shale, silty, dark-gray to medium-dark-gray poorly laminated, contains brachiopods, pelecypods, gastropods, and cephalopods, and especially many

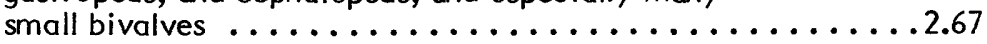

10. Clay shale, silty, medium-dark-gray, poorly laminated, unit grades down to siltstone; contains abundant marine fossils, mostly brachiopods, and sparse fossiliferous nodular limestone concretions . . . . . . . . . . . . I.07

9. Siltstone, medium-gray, contains siderite-cemented trace fossils and burrows as well as few invertebrate fossils; lar ge limestone concretion at base . . . . . . . . . 1.4

8. Siltstone, medium-gray, contains sandy siltstone beds as much as $0.05 \mathrm{~m}$ thick and lensoidal limestone concretions as much as $0.25 \mathrm{~m}$ thick and

7. Siltstone, medium-gray, slightly bioturbated, contains laminae of very fine grained sandstone; contains sparse small brachiopods and pelecypods 
6. Siltstone, clayey, medium-gray, grades down to clay shale; contains in upper part nodular concretions of siderite and in lower part thin concretionary beds of siderite; coalified plant fragments throughout.

5. Clay shale, medium-dark-gray, contains limestone concretions as much as $0.5 \mathrm{~m}$ thick and $2 \mathrm{~m}$ long and thin concretionary beds of siderite $\ldots \ldots \ldots \ldots \ldots \ldots \ldots . . .5$

4. Siltstone, inter laminated with very fine grained sandstone; medium-gray, ripple-bedded, contains thin concretionary beds and small nodules of

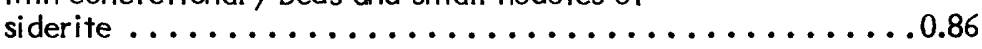

3. Siltstone, medium-gray, micaceous; coalified plant fragments common on bedding surfaces .............. 35

2. Clay shale, silty, becomes less silty toward base; medium-dark-gray, contains thin concretionary beds of siderite and small sider ite nodules

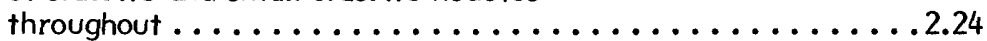

I. Clay shale, dark-gray, very carbonaceous with much plant material; contains small fragments of invertebrate fossils, mostly brachiopod tests...............0.

Total Kendrick Shale Member ............ 21.41

Coal, in Amburgy coal zone..........................

Clay shale, silty, medium-gray, upper $1 \mathrm{~m}$ rooted $\ldots \ldots \ldots \ldots \ldots \ldots .32$

Coal with partings, in Amburgy coal zone....................... 0.74 


\section{REFERENCES CITED}

Furnish, W. M., and Knapp, W. D., 1966, Lower Pennsylvanian fauna from eastern Kentucky--Part I, Ammonoids: Joumal of Paleontology, v. 40, no. 2, p. 296308.

Hennen, R. V., and Reger, D. B., 1914, Logan and Mingo Counties: West Virginia Geological Survey County Report, 776 p.

Huddle, J. W., and Englund, K. J., 1966, Geology and coal reserves of the Kermit and Varney area, Kentucky: U.S. Geological Survey Professional Paper 507, $83 \mathrm{p}$.

Jillson, W. R., 1919, The Kendrick Shale; a new calcareous fossil horizon in the coal measures of eastern Kentucky: Kentucky Department of Geology and Forestry, Series V, Mineral and Forest Resources of Kentucky, v. I, no. 2, p. 96-104.

McKay, E. J., and Alvord, D. C., 1969, Geologic map of the Lick Creek quadrangle, Pike County, Kentucky: U.S. Geological Survey Geologic Quadrangle Map GQ-7I6.

Miller, R. L., 1969, Pennsylvanian formations of southwest Virginia: U.S. Geological Survey Bulletin 1280, 62 p.

Rice, C. L., 1964, Geology of the Lancer quadrangle, Kentucky: U.S. Geological Survey Geologic Quadrangle Map GQ-347. 


\title{
ADOPTION, REDEFINITION, AND EXTENDED USE OF THE NAME COLINSVILLE FORMATION AND ITS MEMBERS AND RELATED FORMATIONS IN WESTERN CONNECTICUT AND WESTERN MASSACHUSETTS
}

\author{
By Rolfe S. Stanley'
}

The name Collinsville was originally proposed by Rice and Gregory (1906) for the rocks cropping out and around the village of Collinsville in the town of Canton, Connecticut. In 1964, Stanley assigned to this formation was divided into two named members: the Bristol Member (lower) named for the rocks in the city of Bristol and the Sweetheart Mountain Member (upper) named for Sweetheart Mountain directly north of Nepaug Reservoir in the Collinsville quadrangle. Gregory actually used the names "Collinsville granite gne iss" and "Bristol granite gneiss" (unit II and 10, respectively, on the preliminary geologic map by Rice and Gregory, 1906) and suggested that the two gneisses were intrusive. Earlier, Percival (1842) had used the names "Canton granitic basin" and "Bristol granitic basin." Although these authors realized that the rocks in these two areas had many similar characteristics, they were not correlated until Stanley (1964) reinterpreted them as volcanic and volcanogenic material and demonstrated stratigraphic symmetry across the isoclinal syncline separating the Collinsville and Bristol domes. Both the Collinsville and Bristol names were retained because they are already in the literature.

The Bristol Member (200-800 m thick) is a heterogeneous unit composed of medium-grained plagioclase-quartz-biotite gneiss with some garnet (with or without chlorite), quartz-plagioclase-mica-garnet gneiss and schist, amphibolite (with or without garnet), layered hornblende gneiss, and rare two-amphibole gne iss. A distinctive zone of pink coticule quartzite is present in the upper part of the member. All the gneisses are distinctly layered and are nonrusty weathering except for a few outcrops in the northeastern part of the Bristol dome. The contact between the Bristol Member and the Sweetheart Mountain Member is gradational over an interval of $5-10 \mathrm{~m}$ and is characterized by an increase in nonrusty weathering, medium- to coarse-grained quartz-plagioclase binary mica schist and a simultaneous decrease in gne iss. Amphibolite layers 30$60 \mathrm{~cm}$ thick are present in the schist. The Sweetheart Mountain is relatively thin $(60-150 \mathrm{~m})$ but is continuous, forming a persistent unit around the periphery of both the Collinsville and the Bristol domes.

Stanley (1964, p. 22) designated the southern face of Sweetheart Mountain between its top and the lowest water level of the Nepaug Reservoir as the type locality of the Collinsville Formation The western side of Route 4 in Collinsville was also designated as a reference locality, which unfortunately does not contain large amounts of plagioclase gne iss so typical of the formation as a whole. Subsequent work in Massachusetts and in Connecticut has shown that the muscovite-bearing gne iss in the western part of the type locality forms a minor part of the formation and is in many respects similar to the binary mica gneiss in the Cobble Mountain Formation, although the two are not physically continuous. Thus, the Bristol Member could legitimately be subdivided into two units-one 
dominated by binary mica gneiss and schist with associated amphibolite and the other characterized by homogeneous plagioclase-rich gneiss. In compiling the bedrock map of Connecticut, John Rodgers (unpub. data, 1980) follows Simpson's stratigraphic divisions and restricts the Bristol Member to the homogeneous plagioclase gneiss and includes all the remaining rocks of Staley's (1964) Bristol Member in the hornblende gne iss member of the Collinsville Formation. Both of the units are well exposed in the Bristol dome.

The Collinsville Formation, or lithically equivalent rocks, has been mapped as such throughout much of western Connecticut. it has been mapped in the Long Hill quadrangle (Crowley, 1968), the Southbury quadrangle (Scott, 1974), the Thomaston quadrangle (Cassie, 1965), the Waterbury quadrangle (Gates and Martin, 1967), the Southington quadrangle (Fritts, 1963), the Bristol quadrangle $(\mathrm{H}$. E. Simpson, unpub. data), and the Southwick quadrangle (Schnabel, 1974). In the Waterbury and Southington quadrangles, these rocks have been called the Hitchcock Lake Member of either the Hartland Formation (Gates and Martin, 1967) or the Waterbury Gne iss (Fritts, 1963). In the Thomaston quadrangle, Cassie (1965) called equivalent rocks the "Reynolds Bridge Gneiss."

Although the Collinsville Formation and its Bristol and Sweetheart Mountain Members were originally defined for rocks in western Connecticut, they are geographically extended into western Massachusetts because they are found in the Granville dome, which bridges the boundary between the two states, and they are also present in both the Shelburne Falls dome and the northern part of the Goshen dome. Precedence for this action has already been established by Schnabel (1974), who used the name "Collinsville Formation of Stanley" in the geological explanation for the map of Southwick quadrangle.

The age of the Collinsville Formation was thought to be Middle Ordovician on the basis of its stratigraphic position above the Taine Mountain Formation (Moretown equivalent) in the Bristol dome and its lithic correlation to members $\underline{B}$ and $\mathrm{C}$ of the Cobble Mountain Formation in the Blandford and Woronoco quadrangles (Hatch and Stanley, 1973). The Cobble Mountain Formation is considered Middle Ordovicion or possibly Middle to Late Ordovician in age, on the basis of the fact that member $A$, the lowermost member of the formation, is a facies equivalent of the Hawley Formation (Hatch and Stanley, 1973, p. 15-16), which is in turn physically continuous with the Cram Hill Member of the Missisquoi Formation of eastern Vermont as used by Doll and others (1961). The age of their Cram Hill is based upon its correlation with Berry's Magog Slate that contains Middle Ordovician graptolites (zone 12, Wilderness-Trenton, Berry, 1962) at Castle Brook near Magog, Quebec.

The coniact between the Collinsville and the Taine Mountain Formations was originally considered depositional although the Collinsville does truncate several members of the Taine Mountain in the Bristol dome (Stanley, 1964, pl. 1). In Massachusetts, Stanley (1978) suggested that the Collinsville Formation in the Shelburne Falls, Goshen, and Granville domes was in thrust contact with the Hawley Formation. The actual contact is not exposed in any of these domes. This interpretation was based on the detailed mapping of the bedrook geology of the Shelburne Falls dome, by L. M. Hall, University of Massachusetts, (unpub. data, 1977) and the gravity survey of Simpson (1974) who showed the Collinsville Formation as a relatively thin $(2,000-2,300 \mathrm{~mm})$ complexly deformed sequence of felsic gneiss and amphibolite. Parts of the Collinsville Formation (plagioclase 
gneiss, for example) are similar to the rocks in the Bronson Hill domes (Fourmile Gneiss of Ashenden, 1973, for example) and may be genetically related to the volcanic arc processes thought to be responsible for many of the gneisses in the Bronson Hill anticlinorium (Robinson and Hall, 1980). Thus, the present position of the Collinsville Formation considerably west of the Bronson Hill anticlinorium supports, but does not prove, the allochthonous nature of the Collinsville Formation west of the Mesozoic basin.

More recently, Robinson and Hall (1980) suggest that the Collinsville Formation is in thrust contact with the Moretown Formation, not the Hawley. This interpretation is consistent with lithic relations in the Bristol and Waterbury domes where the Collinsville rests on rocks lithically similar to the Moretown Formation (Taine Mountain Formation of Connecticut). The suggested tectonic nature of the base of the Collinsville Formation and the lack of proven physical continuity between it and the Cobble Mountain Formation to the west of the Granville dome in Massachusetts make the original age assignment of Middle Ordovician highly questionable. The Collinsville Formation or parts of it could be older (homogeneous plagioclase gneiss, for example), although a Proterozoic $Z$ or Cambrian age does not seem justified at this time.

\section{REFERENCES CITED}

Ashenden, D. D., 1973, Stratigraphy and structure, northern portion of the Pelham Dome, north-central Massachusetts: Massachusetts University Geology Department Contribution 16, 132 p.

Berry, W. B. N., 1962, On the Magog, Quebec, graptolites: American Journal of Science, v. 260, no. 2, p. 142-148.

Cassie, R. M., 1965, Evolution of a domal granite gne iss and its relation to the geology of the Thomaston quadrangle, Connecticut: Madison, University of Wisconsin, Ph.D. thesis, 109 p.

Crowley, W. P., 1968, The bedrock geology of the Long Hill and Bridgeport quadrangles: Connecticut Geological and Natural History Survey Quadrangle Report 24, $81 \mathrm{p}$.

Doll, C. G., Cady, W. M., Thompson, J. B., Jr., and Billings, M. P., 1961, Centennial geologic map of Vermont: Vermont Geological Survey, scale I: 250,000 .

Fritts, C. E., 1963, Bedrock geology of the Southington quadrangle, Connecticut: U.S. Geological Survey Geologic Quadrangle Map GQ-200.

Gates, R. M., and Martin, C. W., 1967, The bedrock geology of the Waterbury quadrangle: Connecticut Geological and Natural History Survey Quadrangle Report 22, 36 p. 
Hatch, N. L., Jr., and Stanley, R. S., 1973, Some suggested stratigraphic relations in part of southwestern New England: U.S. Geological Survey Bulletin 1380, $83 \mathrm{p}$.

Percival, J. G., 1842, Report on the geology of the State of Connecticut: New Haven, Osborn and Baldwin, $495 \mathrm{p}$.

Rice, W. N., and Gregory, H. E., 1906, Manual of the geology of Connecticut: Connecticut Geological Survey Bulletin 6, 273 p.

Robinson, Peter and Hall, 1980, Tectonic synthesis of southern New England, in Wones, D. R., editor, Proceedings, "The Caledonides in the U.S.A.", I.G.C.P. Projec† 27-Caledon ide Orogen, 1979 Meeting, Blacksburg, Virginia: Virginia Polytechnic Institute and State University Memoir 2, p. 73-82.

Schnabel, R. W., 1974, Bedrock geologic map of the Southwick quadrangle, Massachusetts and Connecticut: U.S. Geological Survey Geologic Quadrangle Map GQ-1170.

Scott, R. B., 1974, The bedrock geology of the Southbury quadrangle: Connecticut Geological and Natural History Survey Quadrangle Report 30, 63 p.

Simpson, R. W., Jr., 1974, A gravimetric and structural analysis of the Shelburne Falls dome, Massachusetts: Orono, Maine University, unpublished M.S. Thesis, $58 \mathrm{p}$.

Stanley, R. S., 1964, The bedrock geology of the Collinsville quadrangle: Connecticut Geological and Natural History Survey Quadrangle Report 16, 99 p.

Stanley, R. S., 1978, Bedrock geology between Triassic and Jurassic basin and east flank of the Berkshire massif, Massachusetts [abs.]: Geological Society of America Abstracts with Programs, v. 8, no. 2, p. 300. 


\title{
REDEFINITION OF THE COBBLE MOUNTAIN FORMATION IN SOUTHWESTERN MASSACHUSETTS AND NORTH-CENTRAL CONNECTICUT
}

\author{
By Rolfe S. Stanley' Douglas A. Knapp ${ }^{2}$ and \\ Norman L. Hatch, Jr.
}

The name Cobble Mountain Formation was originally assigned to a group of rocks around and near the Cobble Mountain Reservoir in the southeastern part of the Blandford 7-1/2-minute quadrangle in Massachusetts (Hatch and Stanley, 1973, p. 9-16). These rocks extend northward to Blandford Village (Hatch and Stanley, 1976), eastward to Russell in the adjacent Woronoco quadrangle (Stanley and others, in press) and southward into Connecticut (fig. 9). They have been recognized in the Goshen dome to the north, and lithic equivalents are found in the Granville, Collinsville, Bristol, and Waterbury domes to the south (Sweetheart Mountain Member of the Collinsville Formation, for example).

As originally defined, the formation was divided into a lower member $(\mathrm{Ocl})$ and an upper member (Ocu) (fig. 10). The lower member contains thin-bedded granofels and schist with a thin rusty-weathering schist unit at the base. The upper member is dominantly thick-bedded, silvery-gray, feldspathic gneiss and schist with mappable units of rusty-weathering schist and gneiss. As noted in the original description (Hatch and Stanley, 1973, p. 12) of the upper member, the upper part is generally devoid of feldspathic gneiss and amphibolite but contains aluminous schist, associated serpentinite lenses, and rusty-weathering schist very similar to the rusty-weathering schist in the lower part of the upper member. Furthermore, the very eastern part of the easternmost rusty tongue near the contact with the overlying Goshen Formation contains brown-to-rusty weathering, thin-bedded rocks that are not graded and are more feldspathic than the younger, thin-bedded rocks of the Goshen (Hatch and Stanley, 1973, p. 11-12). Calc-silicate quartzite and vitreous quartzite of the Russell Mountain Formation separate the two units along much of their contact in the Woronoco quadrangle (Stanley and others, in press).

Subsequent mapping by Knapp $(1977,1978)$ in the Southwick and West Granville quadrangles and additional work by Knapp and Stanley (1978) have demonstrated continuity of units in the upper member considered earlier to be lenticular or discontinuous (fig. 9). The original thin-bedded lower member (Ocl) of Hatch and Stanley $(1973,1976)$ is unchanged except that it is now designated member A (Oca, Ocar, fig. 10). The original thick-bedded upper member (Ocu) is here subdivided into three members following the scheme of Knapp (1978). Member B (Ocb, fig. 10) comprises most of the upper unit as formerly used by Hatch and Stanley (1976). It is characterized by silvery-gray feldspathic schist and gneiss and subordinate beds of amphibolite. Lentils of rusty-weathering feldspathic schist and subordinate gne iss in the unit are designated by a separate symbol (Ocbr). A small area of silvery-gray schist rich in garnet is distinguished in the southern part of the Woronoco quadrangle (Ocbgs). Knapp (1978) mapped a

'Department of Geology, University of Vermont, Bur lington, Vermont 05401

2 Department of Geology, Memorial University, St. Johns, Newfoundland, Canada 


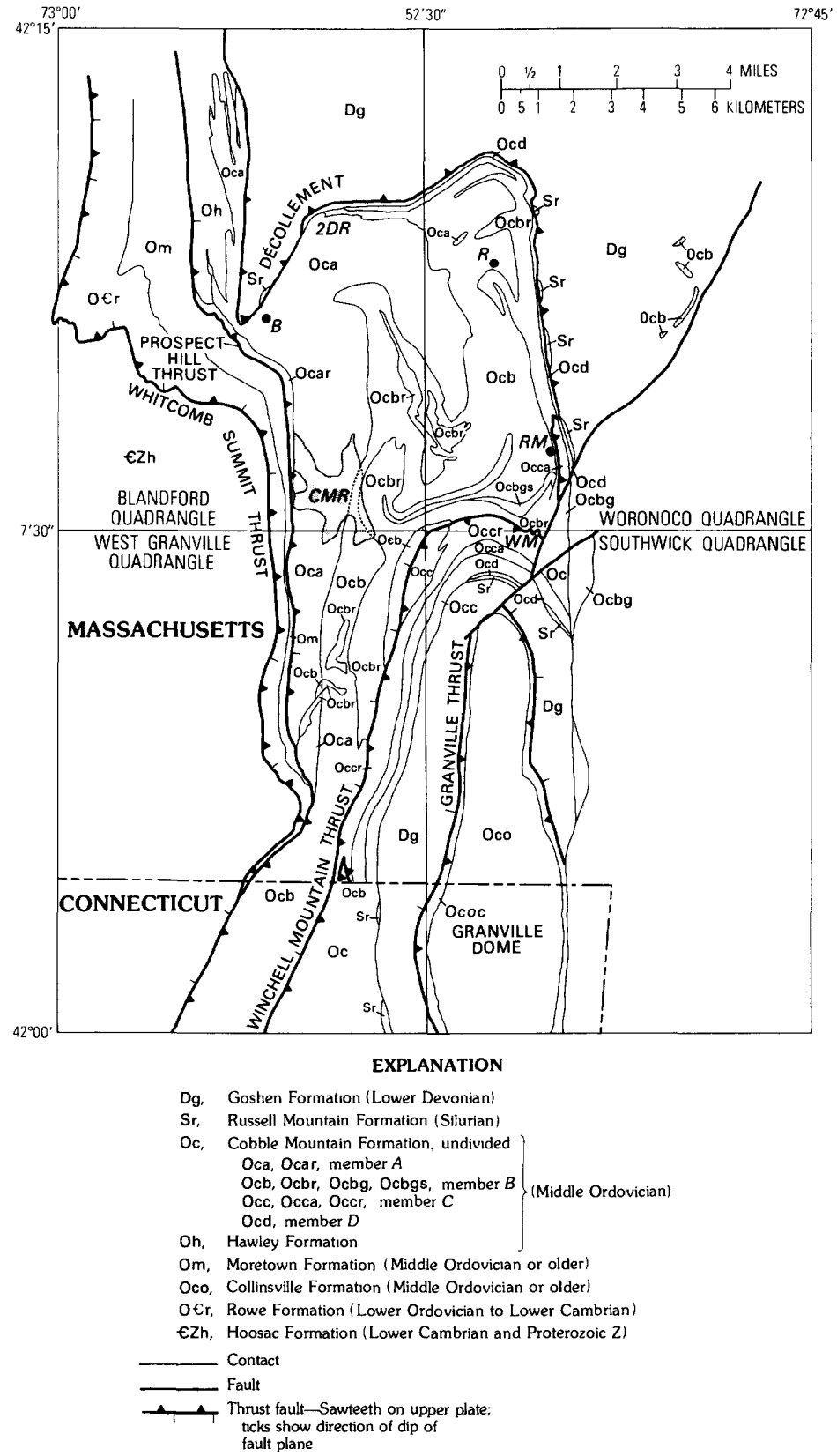

Figure 9.--Generalized geologic map of southwestern Massachusetts and north-central Connecticut showing the distribution of members and map units of the Cobble Mountain Formation. B, Blandford Village; R, Russell; RM, Russell Mountain; WM, Westfield Mountain; 2DR, Second Divsion Road; CMR, Cobble Mountain Reservoir. 


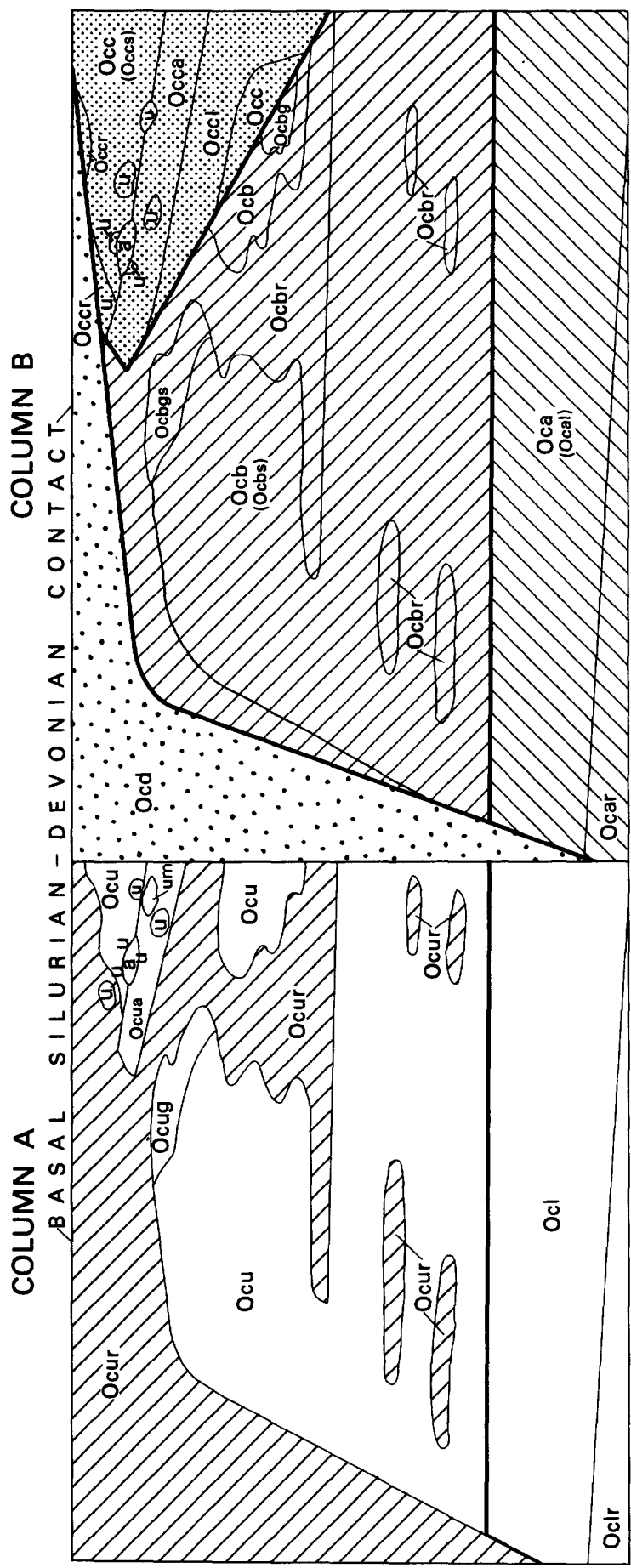

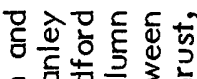

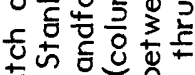

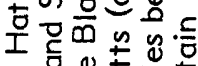

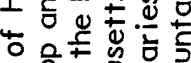

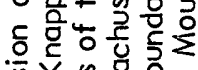
可文员品

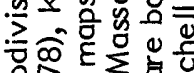

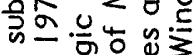

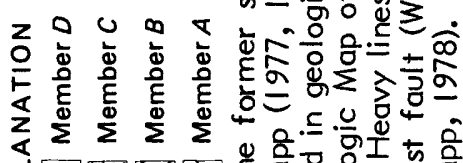

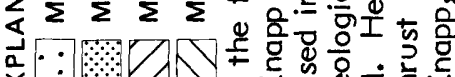

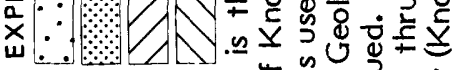

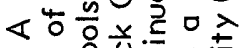
달

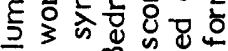
o 8 .

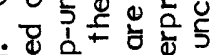
क्ष 政 ह. $\delta$ 훙. :

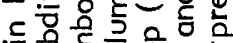

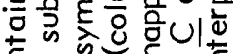

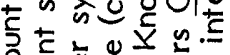

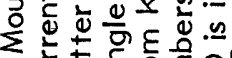

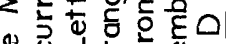

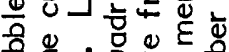

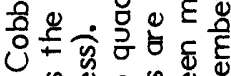
些。. 我

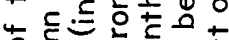
은

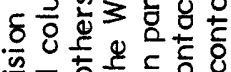

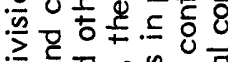

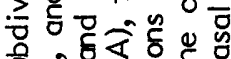

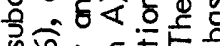
응 ᅯ

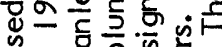

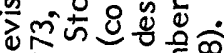

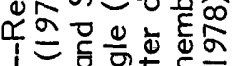
1.

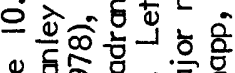

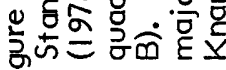
i 
small area in the northeastern part of the Southwick quadrangle of slabby, lightgray, fine- to medium-grained plagioclase-quartz-mica gne iss (Ocbg). He correlated it with the main mass of the member and showed that it is bounded by high-angle faults of Triassic age.

Member $C$ is extensive in the Southwick and Granville quadrangles and is only locally present in the Woronoco quadrangle. It is characterized by brown rusty-weathering schist (Occr) and nonrusty-weathering, silvery-gray, feldspathic schist $(\mathrm{Occ})$ free of gneiss and granofels. The schists are similar to those in member $\underline{B}$, but the absence of gneiss and granofels in member $\underline{C}$ distinguishes it from member B. Near the Connecticut State line, Knapp (1978) separated a small area in member $C$ that did contain gneiss. This is not included in the present definition of member $C$ because it is interpreted as a fault-bounded slice of member $\underline{B}$ (Ocb) in member $\underline{C}$ (Occ) (Knapp, 1978).

Member $\mathrm{C}$ also contains aluminous schist (Occa) with conspicuous kyanite and sillimanite. Magnetite and porphyroblasts of plagioclase are also characteristically present. Contacts with adjacent rocks are sharp. Member $C$ also contains lensoid bodies of serpentinized or steatitized ultramafic rock and mappable bodies of thinly laminated, fine-grained amphibolite. In the Woronoco quadrangle, eight ultramafic bodies are restricted to a thin belt of member $\mathrm{C}$ on Russell Mountain and on the east side of Westfield Mountain. They are mapped within member C (Occ, 2 lenses; Occr, I lens; and Occa, I lens) and along or near the borders of the amphibolite (4 lenses) at the marble quarries on Russell Mountain where the different units of member $C$ are very thin and complexly interlayered. In the Southwick and West Granville quadrangles, three lenses are located within member C (Occa, near the contact with Occ). The serpentinite bodies and their associated finely laminated amphibolite and aluminous schist are interpreted as tectonic clasts or slices within the schist (Occ; Stanley and others, in press). On the north side of the top of Russell Mountain in the Woronoco quadrangle, member $\underline{C}$ appears to interfinger with member $\underline{B}$ (Ocbr) and does not continue north of this latitude.

Member $D$ is unusual in that its contact with the other underlying members of the formation is discordant, and it is also gently truncated by the overlying rocks of the Russell Mountain and Goshen Formations. In the Woronoco quadrangle, it is very thin $(0-60 \mathrm{~m})$ but thickens $(124 \mathrm{~m})$ to the south in the Southwick quadrangle. It consists of dark-brown, fine- to medium-grained, thinly bedded (up to $20 \mathrm{~cm}$ ), but not graded, schist and gneiss locally associated with rusty, graphitc shist and vitreous quartzite. The rocks were recognized by Hatch and Stanley (1973, p. II-12) but not separately mapped until Knapp's work in the Southwick quadrangle (Knapp, 1977, 1978). In the Woronoco quadrangle north of Russell Mountain, member $\mathrm{D}$ rests on member $\mathrm{B}$ (Ocbr), which thins gradually as it is traced north and west into the Blandford quadrangle. There, member $D$ (Ocd) comprises much of what is shown on the Blandford quadrangle map as the upper member (Ocur, fig. 10; Hatch and Stanley, 1976). Between Second Division Road and Blandford Village (2DR and B, fig. 9), member D (Ocd; Ocur on the Blandford map) truncates member $B$ (Ocb; Ocu) and rests on member $A$ (Oca; Ocl). At Russell Mountain and the east side of Westfield Mountain member $D(O c d)$ rests on member $C$ Occa and $\mathrm{Occ}$ ). To the south in the Southwick quadrangle, member $\underline{D}$ (Ocd) rests on a thick section of member $C$ (Occ). Thus, regionally, the lower contact of member $D(\mathrm{Ocd})$ truncates progressively lower stratigraphic levels of the formation. This discordant contact is interpreted as an unconformity rather 
than as a fault because only rocks below and not above the contact are truncated. The upper contact of member $D(\mathrm{Ocd})$ is concordant to the basal contact of the Russell Mountain and Goshen Formations in the Wornoco quadrangle but is truncated at a low angle by the younger rocks near Blandford Village (member B, fig. 9) in the Blandford quadrangle and just north of the Granville dome in the Southwick quadrangle.

The age of the Cobble Mountain Formation is considered to be Middle Ordovician although a Middle Ordovician to Early Silurian(?) age may be possible. The inferred unconformity at the base of member $D$ and the similarity in bedding characteristics with the Goshen Formation would permit an Early Silurian age as the overlying Russell Mountain Formation is considered Middle Silurian (Hatch and others 1970, p. B7-B9). The contact of member $\mathrm{C}$ with member $\mathrm{B}$ is interpreted as a thrust fault based on truncated units on both sides of the surface (Knapp, 1977, 1978). Because its upper surface is unconformably overlain by member $D$, member $C$ cannot be younger than member $D$. Although member $C$ does contain clasts and slivers of older Rowe-like rocks (fig. 9), the similarity between the main mass of member $C$ (Occ, Occr) and the schist in member B suggests a similar age. Member $\bar{C}$ is thought to be a lateral facies of member $B$ with Middle or Late Ordovician displacement being responsible for the present lithic sequence.

The likely Middle Ordovician age for the Cobble Mountain Formation is based on the important facies relationship between the lowermost member of the formation (member A) and the Hawley Formation directly north of Blandford Village in the Blandford quadrangle (Hatch and Stanley, 1973, p. 7-8; 1976). The contact between the two facies is marked by a gradual change in composition and extensive interlayering of the two units on scales ranging from a few millimeters to tens of meters along a strike distance of $5-6 \mathrm{~km}$. Member $B$ is younger than member $A$ as evidenced by graded beds near, and in a few places across, the contact that consistently top towards member B. The quality of grading, however, does diminish rapidly across the contact (Hatch and Stanley, 1976).

The Hawley Formation is physically continuous with the Cram Hill Member of the Missisquoi Formation of eastern Vermont as used by Doll and others (1961). The age of the Cram Hill has been based upon its correlation with the Magog Slate that contains Middle Ordovician graptolites (zone 12, WildernessTrenton, Berry, 1962) at Castle Brook near Magog, Quebec. Near Montpelier, Vt., the Cram Hill disappears below the basal Silurian-Devonian unconformity; similar rocks reappear for a short distance near the International Border southwest of Lake Memphremagog. The Castle Brook locality is thus not continuous with the Cram Hill. Furthermore, the discontinuous nature of both the Cram Hill and the Magog coupled with the complexity of the structure between Blandford Village, Mass., and the Castle Brook locality adds further uncertainty to the likely Middle Ordovician age assignment for the Cobble Mountain Formation.

The revised definition of the Cobble Mountain Formation proposed here is unconventional in containing a thrust fault (Winchell Mountain thrust) at the base of member $C$ and an unconformity at the base of member $D$ (Knapp, 1977, 1978). The fault is not considered a serious problem because the predominant lithology in member $C$ is identical with the schist in member $B$. What must be kept in mind is that member $C$ may well be a lateral facies of member $B$ and not a younger unit as is suggested by their present arrangement (figs. $\overline{9}, 10$ ). Including units separated by an unconformity in one formation, we feel, is warranted by the fact 
that the distribution of member $C$ in and around the Granby-Granville domes to the south in western Connecticut is still unclear. Until the regional extent and relations of member $\underline{D}$ are better understood, it should be retained in the Cobble Mountain Formation.

\section{REFERENCES CITED}

Berry, W. B. N., 1962, On the Magog, Quebec, graptolites: American Journal of Science, v. 260, no. 2, p. 142-148.

Doll, C. G., Cady, W. M., Thompson, J. B., Jr., and Billings, M. P., 1961, Centennial geologic map of Vermont: Vermont Geological Survey, scale $1: 250,000$.

Hatch, N. L., Jr., and Stanley, R. S., 1973, Some suggested stratigraphic relations in part of southwestern new England: U.S. Geological Survey Bulletin 1380, 83 p.

Hatch, N. L., Jr., and Stanley, R. S., 1976, Geologic map of the Blandford Quadrangle, Hampden and Hampshire Counties, Massachusetts: U.S. Geological Survey Geologic Quadrangle Map GQ-13/2.

Hatch, N. L., Jr., Stanley, R. S., and Clark, S. F., Jr., 1970, The Russell Mountain Formation, a new stratigraphic unit in western Massachusetts: U.S. Geological Survey Bulletin 1324-B, 10 p.

Knapp, D. A., 1977, Structure and stratigraphy of the lower Paleozoic section along the east limb of the Berkshire Massif: Burlington, Vermont University, unpublished M.S. Thesis, 125 p.

Knapp, D. A., 1978, Geologic map of the Granville area, Hampden County, Massachusetts: U.S. Geological Survey Open-File Map 78-27I.

Knapp, D. A., and Stanley, R. S., 1978, Thrust faults in the lower Paleozoic section along the east limb of the Berkshire massif, southwestern Massachusetts [abs.]: Geological Society of America Abstracts with Programs, v. 10, no. 2, p. 71.

Stanley, R. S., Clark, S. F., Jr., and Hatch, N. L., Jr., in press, Bedrock geologic map of the Woronoco quadrangle, Hampden and Hampshire Counties, Massachusetts: U.S. Geological Survey Geologic Quadrangle Map GQ-1565. 


\title{
THE PUTNEY VOLCANICS IN SOUTHEASTERN VERMONT AND NORTH-CENTRAL MASSACHNSETTS
}

\author{
By Newell J. Trask
}

The Putney Volcanics (Hepburn, 1972a, b) is compsoed of fine-grained, poorly foliated, light-greenish-gray phyllite and granulite, both containing interbedded gray phyllite, that form a belt as much as $130 \mathrm{~m}$ wide in the Connecticut Valley synclinorium of southeastern Vermont and north-central Massachusetts. Lenses of quartz-pebble conglomerate containing fragments of quartzite and slate in a slate matrix are found in a few outcrops along the belt on its east side. This belt of phyllite and granulite was assigned to the Standing Pond Volcanics on the 1955 Geologic Map of New Hampshire (Billings, 1956) and to the Standing Pond volcanic member of the Waits River Formation on the 1961 Geologic Map of Vermont (Doll and others, 1961); it is the easternmost of several bands of metavolcanic rocks mapped as Standing Pond on the Vermont map. The rocks of this easternmost band are predominatly quartz-plagioclase-muscovite phyllite and granulite and thus are considerably less mafic than the typical Standing Pond (Doll and others, 1961). Also, this belt cannot be traced physically into the type Standing Pond. Therefore, the name Putney Volcanics is here adopted for the rocks of this belt for U.S. Geological Survey usage; and this name is extended southward along strike into Massachusetts.

The Putney Volcanics is bordered on the east by dark-gray slate and phyllite containing interlaminae of light-gray quartzite of the Littleton Formation, and on the west by dark-gray phyllite, light-gray quartzite, and rare brown-weathering limestone of the Gile Mountain Formation (Doll and others, 1961; Trask, 1964). The Putney Volcanics weathers buff to light brownish gray and forms a mappable unit between the darker gray Littleton and Gile Mountain Formations. Although not conclusive, evidence from truncated crossbedding in the Littleton Formation immediately to the east of the Putney Volcanics near Putney Station, Vt., suggests that the top of the sequence is to the east.

The Littleton Formation is Early Devonian in age (Billings, 1956); the age of the Gile Mountain is uncertain but is generally regarded as Devonian on the basis of regional relationships (Doll and others, 1961). The Putney Volcanics is therefore probably Devonian.

The Putney Volcanics extends from approximately $8 \mathrm{~km}$ north of Springfield, $V t$. , to $1.5 \mathrm{~km}$ northwest of Bernardston, Mass.--a total of approximately $80 \mathrm{~km}$. The belt is offset repeatedly by steeply plunging, sinistral folds and one fault north of Brattleboro, Vt. The thickness ranges from a few meters to $130 \mathrm{~m}$ along strike.

Igranulite--a metamorphic rock consisting of even-sized, interlocking mineral grains without preferred orientation. 


\section{REFERENCES CITED}

Billings, M. P., 1956, The geology of New Hampshire, Part II - Bedrock geology: New Hampshire Planning and Development Commission, 203 p.

Doll, C. H., Cady, W. M., Thompson, J. B., Jr., and Billings, M. P., 1961, Centennial Geologic Map of Vermont: Vermont Geological Survey, scale $1: 250,000$.

Hepburn, J. C., 1972a, Geology of the metamorphosed Paleozoic rocks in the Brattleboro area, Vermont: Cambridge, Massachusetts, Harvard University, unpublished Ph.D. thesis, 342 p.

, 1972b, Geology of the Guilford dome area, southeastern Vermont: New England Intercollegiate Geological Conference, 64th, Annual Meeting, Burlington, Vermont, October 13-15, Guidebook for field trips in Vermont: p. 231-243.

Trask, N. J., 1964, Stratigraphy and structure in the Vernon-Chesterfield area, Massachusetts, New Hampshire, and Vermont: Cambridge, Massachusetts, Harvard University, unpublished Ph.D Thesis, 99 p. 


\section{AUTHOR INDEX}

*Abbott, W. H., Al8, 34

Anderson, J. J., see Rowley, P. D., A53 (2), 61, 63, 79

Andrews, G. W., see Abbott, W. H., Al8, 34

*Ashwal, L. D., Al9, 22, 28,

33,58

*Bateman, P. C., Al3, 33, 37, 69,79

Bateman, P. C., A79

Bentley, R. D., see Swanson,

D. A., A6, 7, 11, 16, 24 (2),

$25,26,29,31,35$ (2), 43,

$55,57,59,60,65,66,73$,

$80,81,82,84,85$ (2)

Bergström, S. M., see Harr is,

A. G., A5I, 56, 64

*Blackwelder, B. W., A6, 22,

62, 86

Blackwelder, B. W., see Ward,

L. W., A6, 17, 19, 24, 33,

$47,55,68,75$

Bowman, H. W., see Sarna-

Wojcicki, A. M., A27, 75

Campbell, R. H., see Yerkes,

R. F., Al2, 14, 15, 16, 17,

20, 21, 25 (2), 27, 41, 42,

44, 45, 46, 50, 57, 61, 66,
$67,69,71,72,73,78(2)$,

79 (2), 81, 86

Case, J. E., see Tysdal,

R. G., Al3, 26 (2), 50, 70

Cavanaugh, E. T., see

Merewether, E. A., A66

Chappell, B. W., see Bateman,

P. C., Al3, 33, 37, 69, 79

Cobban, W. A., see Merewether, E. A., A66

Collinson, J. W., see Wardlaw, B. R., A30, 32, 38, 48, 52, 54 (2), 64

*Connelly, William, A70

*Cook, H. E., A84

*Cunn ingham, C. G., A9, 32, $37,47,48,62$

Cunningham, G. C., see Rowley, P. D., A53 (2), 61, 63, 79

Cunningham, C. G., see Steven, T. A., AlI, 20, 22, 77

*Denny, C. S., A55

Denny, C. S., see Owens, J.P., A9, 36, 38, 52, 71

Dibblee, T. W., Jr., see Murata, K. J., A45, 47

Dockter, R. D., see Silverman, M. L., A73

Douglass, R. C., A44, 59, 60, 74

* Senior author of paper

with multiple authorship 
Douglass, R. C., see Skipp, Betty, A5, 8 (2), 30, 37, 72

Drinkwater, J. L., see Murata, K. J., A45, 47

Ethington, R. L., see Harr is, A. G., A5I, 56, 64

Fisher, M. A., A49, 81

Fouch, T. D., A70

Gohn, G. S., see Ward, L. W., A6, 17, 19, 24, 33, 47, $55,68,75$

Goldsmith, Richard, A4, 8, 9, $10,11,14,15,27,32,34$, $35,37,38,44,45,46,47$, $48,49,50,57,58(3), 59$, 61 (2), 65, 67, 68, 69, 72, $73,76(2), 83,91$

Gutschick, R. C., see

Sandberg, C. A., A18, 42 Hall, D. J., see Ashwal,

L. D., A19, 22, 28, 33, 58 Halley, R. B., see Palmer, A. R., Al3, 2I, 23 (2), 25, $31,54,60,62,76,86$ Harrell, James, see Kepferle,

R. C., A28 (2), 36, 50, 104 *Harr is, A. G., A5I, 56, 64 Harris, L. D., Al4 Harwood, D. S., A12, 83 Hatch, N. L., Jr., see

Ratcliffe, N. M., A42, 80,83 Hatch, N. L., Jr., see Stanley,

R. S., A15, 127 Hill, J. M., see Lankford, S. M., A23, 80
Hoggan, R. D., see Skipp, Betty, A5, 8 (2), 30, 37, 72

Holdsworth, Brian, see Jones,

D. L., A69

Hooper, P. R., see Swanson, D. A., $A 6,7,11,16,24$ (2), 25, 26, 29, 31,35 (2), 43, 55, 57, 59, 60, 65, $66,73,80,81,82,84,85$ (2) Hotz, P. E., Al7 Howells, Lewis, A29, 36 Hudson, Travis, A52 Imlay, R. W., see Pipiringos,

G. N., A19, 63, 68, 74 (2)

Jones, D. L., A53

* Jones, D. L., A69

Keith, T. E. C., see Silberman, M. L., A73

Kepferle, R. C., A7

*Kepferle, R. C., A28 (2), 36, 50, 104

Knapp, D. A., see Stanley,

R. S., A15, 127

Krieger, M. H., A34 (2)

*Krushensky, R. D., A45, 54

*Lankford, S. M., A23, 80

Lemon, E. M., see McCartan,

Lucy, A82, 110

Leo, G. W., see Ashwal, L. D., A19, 22, 28, 33, 58

Lovering, T. S., see Morr is, H. T., A5, 7, 18, 28, 40, 41, 52, 56 (3), 71, 75, 77, 78 Maughan, E. K., see Wardlaw, B. R., A32, 38, 48, 54 (2), 64 May, F. E., A39 
Maynard, J. B., see Kepferle, R. C., A28 (2), 36, 50, 104 *McCartan, Lucy, A82, 110 McLean, Hugh, A7 Mehnert, $H$. H., see Steven, T. A., AlI, 20, 22, 77 *Merewether, E. A., A66 Minard, J.P., see Owens, J. $P ., A 6,10,16$ Monroe, W. H., see Krushensky, R. D., A45, 54 Moore, G. W., see Nilsen, T. H., A49

Moore, G. W., see von Huene, Roland, $A 81$

Moore, J. C., see Connelly, William, A70

Moore, J. C., see von Huene, Roland, A8I

* Moore, W. J., A2I

*Morr is, H. T., A5, 7, 18, $28,40,41,52,56(3)$, $71,75,77,78$

*Murata, K. J., A45, 47

Naeser, C. W., see Steven, T. A., All, 20, 22, 77

*Nilsen, T. H., A49 Osberg, P. H., A20, 46, 67, 82,84

Otton, J. K., A5, 14

*Owens, J. P., A6, 9, 10, $16,36,38,52,71$

Owens, J. P., see Denny, C. S., A55
*Palmer, A. R., Al3, 2I, 23 (2), $25,31,54,60,62,76,86$ *Peterson, Fred, A30, 33, 49, 53, $67,71,76,77,85$

Pierce, W. G., A4l, 83 *Pipiringos, G. N., A19, 63, 68, 74 (2)

Pipiringos, G. N., see Peterson, Fred, A30, 33, 49, 53, 67, 7I, $76,77,85$

Pojeta, John, Jr., All, 15, 21, 27, $31,40,46,51,57,84$ Poore, R. Z., see Ward, L. W., A6, 17, 19, 24, 33, 47, 55, 68, 75 Pryor, W. A., see Kepferle, R. C., A28 (2), 36, 50, 104 *Ratcliffe, N. M., A42, 80, 83 Reinhardt, Juergen, A4, 5, 29, 36, $39,42,65$

Rice, C. L., A9, 38, 117

Robinson, Peter, see Ashwal, L. D., Al9, 22, 28, 33, 58

Roedder, Edwin, A22

Ross, R. J., Jr., see Harris, A. G., A5I, 56, 64

*Rowley, P. D., A53 (2), 61, 63, 79

Rubin, Meyer, see Denny, C. S., A55

Russell, P. C., see Sarna-Wojcicki, A. M., A27, 75

*Sandberg, C. A., Al8, 42

*Sarna-Wojcicki, A. M., A27, 75

Schleicher, D. L., see Skipp, Betty, A5, 8 (2), 30, 37, 72

*Segerstrom, Kenneth, A44 
*Silberman, M. L., A73

Sirkin, L. A., see Denny,

C. S., A55

*Skipp, Betty, A5, 8 (2),

$30,37,72$

*Solem, Alan, A I2, 39, 51, 72

Sorensen, M. L., see Moore,

W. J., A21

Staatz, M. H., AI3, 30

Stanley, R. S., A10, 16,

75,123

*Stanley, R. S., A15, 127

*Steven, T. A., All, 20,

22,77

Steven, T. A., see

Cunningham,C. G., A9,

$32,37,47,48,62$

Steven, T. A., see Rowley,

P. D., A53 (2), 61, 63, 79

Stotelmeyer, R. B., see

Segerstrom, Kenneth, A44

Suczek, C. A., see Jones,

D. L., A69

*Swanson, D. A., A6, 7, II,

$16,24(2), 25,26,29,31$,

35 (2), 43, 55, 57, 59, 60,

$65,66,73,80,81,82,84$,

85 (2)

Taylor, M. E., see Cook,

H. E., A84

Thaden, R. E., A4, 62

Thayer, T. P., Al2

Trask, N. J., A60, 133

Tweto, Ogden, A43

*Tysdal, R. G., Al3,

$26(2), 50,70$
Van Horn, Richard, A20, 40, 64

*von Huene, Roland, A8I

Waitt, R. B., Jr., A40, 41, $43,64,70,77$

*Ward, L. W., A6, 17, 19, 24, 33,

$47,55,68,75$

Ward, L. W., see Blackwelder,

B. W., A6, 22, 62, 86

*Wardlaw, B. R., A30, 32, 38,

$48,52,54$ (2), 64

Wardlaw, B. R., A63

Weems, R. E., see McCartan,

Lucy, A82, 110

White, D. E., see Silberman,

M. L., A73

Williams, F. E., see

Segerstrom, Kenneth, A44

Wright, T. L., see Swanson,

D. A., A6, 7, 11, 16,

24 (2), 25, 26, 29, 31,

35 (2), 43, 55, 57, 59,

$60,65,66,73,80,81$,

$82,84,85(2)$

Wrucke, C. T., see Jones,

D. L., A69

*Yerkes, R. F., A12, 14, 15,

$16,17,20,21,25$ (2),

27, 41, 42, 44, 45, 46,

$50,57,61,66,67,69$,

$71,72,73,78(2), 79$,

$(2), 81,86$

Yochelson, E. L., see

Solem, Alan, A12, 39,

51,72

Zartman, R. E., see Ashwal,

L. D., A19, 22, 28, 33, 58 

